\title{
LA INVESTIGACIÓN EN MARCAS DE TERRITORIO Y DIPLOMACIA PÚBLICA EN ESPAÑA. UN ESTUDIO BIBLIOMÉTRICO DE LAS REVISTAS CIENTÍFICAS ESPAÑOLAS ESPECIALIZADAS EN COMUNICACIÓN INDEXADAS EN LATINDEX (1980-2016)
}

\author{
Marc Compte-Pujol* \\ Universidad de Vic. Universidad Central de Cataluña. \\ Beatriz de Urquijo** \\ Universidad de Ciencias Aplicadas Hanze \\ Kathy Matilla ${ }^{* * *}$ \\ Universidad Ramón Llull
}

\begin{abstract}
Resumen: Este artículo recoge los resultados de un estudio bibliométrico sobre la investigación en marcas de territorio y diplomacia pública, publicada en una muestra de las revistas científicas españolas especializadas en Ciencias de la Comunicación desde el año 1980 hasta febrero de 2016. Para ello, se vaciaron todos los números de las 65 cabeceras indexadas en el directorio de Latindex, obteniendo un universo de 15.082 artículos, de los cuales únicamente 123 correspondieron a temáticas relacionadas con la investigación en marcas de territorio y diplomacia pública. Los resultados del análisis de la muestra permiten sistematizar y ahondar en el conocimiento de la investigación sobre el objeto de estudio en España.

Palabras clave: Bibliometría; Ciencias de la Comunicación; diplomacia pública; España; Latindex; marcas de territorio; relaciones públicas.

Title: RESEARCH ON PLACE BRANDING AND PUBLIC DIPLOMACY IN SPAIN. A BIBLIOMETRIC STUDY OF THE SPANISH SCIENTIFIC JOURNALS SPECIALIZED IN COMMUNICATION INDEXED IN LATINDEX (1980-2016).

Abstract: This article presents the results of a bibliometric study on research on place branding and public diplomacy published by a sample of the Spanish scientific journals specialized in Communication from 1980 until February 2016. To do so, all numbers of the 65 headers indexed in the Latindex directory were considered, obtaining a universe of 15,082 items, of which 123 appeared to be related to place branding and and public diplomacy. Results of the study may help to systematize and deepen the knowledge of both research areas in Spain. Keywords: Bibliometrics; communication sciences; public diplomacy; Spain; Latindex; place branding; public relations.
\end{abstract}

\section{INTRODUCCIÓN}

Las marcas de territorio y la diplomacia pública son dos campos académicos y profesionales en constante crecimiento a escala global. A pesar de contar con una literatura independiente, se observa que se ha hecho cada vez más frecuente concebir ambas prácticas como un todo capaz de coordinarse a nivel estratégico, con el fin de lograr una comunicación y promoción eficaz de una ciudad, región o país determinado. Prueba de esta creciente interrelación conceptual es el título de la revista de referencia internacional sobre la comunicación y promoción de territorios, Place Branding and Public Diplomacy -editada por Palgrave Macmillan-, que justifica, en su web corporativa, la convergencia de ambos términos, del siguiente modo:

Place branding is the practice of applying brand strategy and other techniques and disciplines-some deriving from commercial practice, others newly developed- to the economic, social, political and cultural development of cities, regions and countries. Public diplomacy is the process by which an international actor-often but not exclusively a country - conducts foreign policy by engaging a foreign public. Public Diplomacy and Place Branding are not synonyms but their overlaps are sufficient to justify a journal which considers both activities in their own right and at their point of convergence. Both Place Branding and Public Diplomacy are significantly, but not exclusively, concerned with reputation management.

\footnotetext{
${ }^{*}$ marc.compte@uvic.cat

***a.deurquijo@gmail.com

***kathyms@blanquerna.url.edu

Recibido: 04-04-2016; 2 ${ }^{\mathrm{a}}$ versión: 20-09-2016; aceptado: 03-10-2016.
}

COMPTE-PUJOL, M.; DE URQUIJO, B. y MATILLA, K. La investigación en marcas de territorio y diplomacia pública en España. Un estudio bibliométrico de las revistas científicas españolas especializadas en Comunicación indexadas en Latindex (1980-2016). Anales de Documentación, 2016, vol. 19, nº 2. Disponible en: http://dx.doi.org/10.6018/analesdoc.19.2.255741. 


\subsection{LAS MARCAS DE TERRITORIO}

La paternidad del concepto "marcas de territorio" o place branding, del cual derivan variantes terminológicas como city branding, nation branding, o country branding, suele atribuírsele a Simon Anholt alrededor de 1996 (Kaneva, 2011), aunque la profesión y la investigación en comunicación y promoción de territorios serían anteriores a esta fecha (Dinnie, 2004; Kavaratzis y Ashworth, 2005; Szondi, 2008), encontrando sus orígenes en el ámbito turístico, más concretamente en la promoción y el marketing de destinos (De San Eugenio, 2012, p. 84; Huertas, 2014, p. 8).

A día de hoy y probablemente debido a encontrarse aún en una etapa emergente, los profesionales y académicos de las marcas de territorio no coinciden en una definición consensuada sobre su objeto de estudio, a lo cual debe sumarse una confusión terminológica y conceptual generalizada, especialmente destacable en tanto que afecta a conceptos capitales como los de "comunicación", "marketing" y "branding", usados mayoritariamente de un modo indistinto e inexacto, incluso a nivel académico (Govers, 2011; Hankinson, 2010; Lucarelli y Brorström, 2013). Una confusión que podría explicarse por la gran diversidad e interdisciplinaridad en los perfiles que han abordado las marcas de territorio (sociólogos, geógrafos, politólogos, etc.), quienes, en ocasiones, han mostrado evidencias de un escaso conocimiento de la literatura de referencia en branding, en marketing, en comunicación, o en relaciones públicas, sobre cuyas bases teóricas se observa que se sustenta la especialidad de las marcas de territorio.

Lucarelli y Brorström (2013, p. 65) proponen definir las marcas de territorio como el "fenómeno general de marketing, branding, promoción y regeneración de una ciudad, región y/o ubicación particular". Una definición que aunque se pretende integradora, no contempla el papel que juegan la comunicación y las relaciones públicas en el fenómeno y que aparece descrito en la literatura especializada; disciplinas hacia las cuales evoluciona la práctica de la profesión de las marcas de territorio (Fernández-Cavia y Huertas, 2014; Huertas, 2014; Kjærgaard Rasmussen y Merkelsen, 2012). En este sentido, Govers y Go (2009) afirman que el objetivo fundamental de las marcas de territorio será la obtención de una reputación favorable entre los públicos internos y externos ${ }^{1}$, partiendo siempre de la esencia del lugar, es decir, de su personalidad o identidad. Una reputación que deberá ser analizada mediante el estudio de las percepciones de los públicos de un territorio, y cuya evaluación debe servir como punto de partida sobre el cual desarrollar la gestión del presente y el futuro del territorio en cuestión (Anholt, 2010a) para que un buen gestor de marcas de territorio conozca, evalúe y mida ${ }^{2}$ la imagen percibida socialmente -la reputación- de su ciudad, región o país.

\subsection{LA DIPLOMACIA PÚBLICA}

El término diplomacia pública fue acuñado por el estadounidense Edmond Gullion en 1965, si bien conceptualmente ya estaba presente en el discurso de paz del presidente de los EE.UU., Woodrow Wilson, el 8 de enero de 1918, en el primero de sus Catorce Puntos, en el que se abogaba para que la diplomacia fuera una práctica abierta y transparente, censurando la diplomacia tradicional que venía practicándose como profesión desde 1815 (Oviamionayi, 2004, p. 217-220).

Si bien su práctica es relativamente antigua y se encuentra muy generalizada entre los gobiernos de todo el mundo, también es cierto que como disciplina o subdisciplina académica es mucho más reciente $\mathrm{y}$, a nivel internacional, su investigación ha sido escasa y prácticamente limitada a las universidades estadounidenses (Oviamionayi, 2004, p. 224).

Al igual que las marcas de territorio, la diplomacia pública es una especialidad difícil de definir (La Porte, 2007; Melissen, 2005), de ahí que también sea considerada un campo académico confuso (Oviamionayi, 2004, p. 233). Aún así, podemos entender la diplomacia pública como aquella "estrategia de información y persuasión dirigida a una audiencia extranjera con el fin de conseguir una opinión favorable para la política exterior de un país u organización" (La Porte, M.T., 2007, p. 26). También se la conoce como "poder blando", en tanto que se basa en "la capacidad de un actor político para incidir en las acciones o intereses de otros actores valiéndose de medios culturales e ideológicos" (Rodríguez Gómez, 2013, p. 954).

\subsection{BIBLIOMETRÍA EN MARCAS DE TERRITORIO Y DIPLOMACIA PÚBLICA}

Para poder contribuir y ampliar un área de investigación, es fundamental el estudio de la literatura anteriormente publicada (Feeley, 2008). Para ello, son ideales los estudios bibliométricos (Borgman y Furner, 2002; De Bellis, 2009; Narin et al., 1994; Peres Vanti, 2002; Repiso, 2012; Schmoch y Schubert, 2009; Thelwall, 2008), que contribuyen con condensados de datos y análisis temáticos al fomento de la producción científica integral (Baladrón-Pazos et al., 2014; López-Meneses et al., 2015), así como al estudio de la evolución de una disciplina en particular (De-Filippo, 2013). 
En el caso específico de las marcas de territorio y la diplomacia pública, son temáticas que cuentan con un soporte bibliográfico anterior incluso a la constitución de los términos en cuestión (Dinnie, 2004; Manfredi Sánchez, 2011; Szondi, 2008). Una situación atípica que hace especialmente difícil la detección de la literatura publicada sobre comunicación y promoción de territorios durante el siglo XX, por ejemplo, puesto que han podido ser muchos y muy diversos los términos potencialmente utilizados para hacer referencia a un mismo $-\mathrm{O}$ similar- objeto de estudio. Asimismo, también es frecuente que en épocas posteriores a la generalización de dichos vocablos, éstos sigan sin usarse en los títulos de las investigaciones sobre la materia (Oviamionayi, 2004, p. 234), dificultando aún más la labor bibliométrica.

Quizás por eso, si bien las revisiones de la literatura son relativamente frecuentes en marcas de territorio y diplomacia pública (ver por ejemplo: De San Eugenio, 2013; Dinnie 2004; Lucarelli y Berg, 2011; Oviamionayi, 2004; o Van Ham, 2008; entre otros), no lo son tanto sus estudios bibliométricos, excepto, tal vez, el estudio de Pike (2002), quien condujo un análisis de la literatura internacional publicada en inglés entre 1974 y el año 2000 en el área específica de marca de destino -subcategoría de las marcas de territorio-, ofreciendo un primer mapa sobre las metodologías, mercados, destinos y temas más estudiados dentro de esta rama de estudio.

A escala nacional y en castellano, detectamos el trabajo de Canel y Sanders (2010), quienes realizaron una revisión bibliográfica para fijar el estado de la cuestión de las investigaciones sobre comunicación de los gobiernos, paraguas conceptual bajo el cual incluyen la diplomacia pública, pero que se centraba en aspectos parciales de la comunicación política, dando una importancia muy limitada a la diplomacia pública en particular.

En definitiva, se observa una escasez de estudios bibliométricos específicos en nuestra área de estudio en particular, por lo que para poder efectuar algún tipo de discusión teórica con los resultados de nuestra investigación empírica, se ha optado por ampliar la búsqueda a estudios bibliométricos más genéricos, concretamente del ámbito de la Comunicación, limitados específicamente a una muestra de revistas españolas.

Se observa que la meta-investigación en Comunicación se ha convertido en los últimos tiempos en un objeto de estudio de interés creciente entre la comunidad investigadora española, algo ya apuntado por Baladrón-Pazos et al. (2014, p. 50). Los soportes más frecuentes de análisis son las revistas académicas (Baladrón-Pazos et al., 2014; Fernández-Quijada, 2012; López-Meneses et al., 2015; Martínez-Pecino et al., 2013; Repiso y Fonseca, 2012; Zugasti, 2013), así como varios estudios bibliométricos sobre tesis doctorales (Castillo y Xifra, 2006; Díaz Campos, 2014; o Repiso et al., 2011a, 2011b, 2013).

La mayoría de los trabajos bibliométricos españoles se centra en sub-temáticas concretas de la Comunicación, como la Publicidad, las Relaciones Públicas, la Ética Periodística, el Cine, o la Televisión o la Radio. Son muy pocos los estudios bibliométricos que analizan las Ciencias de la Comunicación en su globalidad, a excepción, de los de Castillo y Carretón (2010), Castillo et al. (2012) y Fernández-Quijada (2012). Se observa que ninguno de ellos considerara la diplomacia pública ni las marcas de territorio como temáticas de búsqueda en la categorización para el análisis de contenido, por lo que tampoco fueron mencionadas como áreas de investigación dentro de los resultados de análisis.

\section{OBJETIVOS Y PREGUNTAS DE INVESTIGACIÓN}

El objetivo principal de nuestro trabajo es trazar un marco de referencia sobre los estudios de: (1) marcas de territorio y (2) diplomacia pública publicados en las revistas científicas españolas especializadas en el área de Ciencias de la Comunicación indexadas en Latindex.

Para ello, buscamos explorar las siguientes preguntas de investigación:

(PI1) ¿Qué porcentaje del total de artículos publicados están relacionados con las marcas de territorio y la diplomacia pública?

(PI2) ¿Cómo se distribuyen a nivel temporal dichos artículos?

(PI3) ¿Cuál es la distribución de género de los autores?

(PI4) ¿Pueden identificarse algunos autores predominantes?

(PI5) ¿De qué región de España provienen? 
(PI6) ¿Cuál es el grado de colaboración de los autores por artículo?

(PI7) ¿Qué universidades están más especializadas en marcas de territorio y diplomacia pública?

(PI8) ¿Qué revistas publican artículos relacionados con esta temática?

(PI9) ¿En qué regiones de España se editan?

(PI10) ¿Qué términos son los más usados en las palabras clave?

(PI1) Dentro de las sub-temáticas de estudio que abarcan las marcas de territorio y la diplomacia pública, ¿cuáles son las más estudiadas?

(PI12) ¿Qué idiomas son los más utilizados?

(PI13) ¿Qué ciudades, regiones y/o países son los más estudiados, desde el punto de vista de marcas de territorios y diplomacia pública?

(PI14) ¿Cuáles son las metodologías de investigación más frecuentes?

(PI15) ¿Qué porcentaje de estudios tratan, específicamente, la influencia de internet y las redes sociales?

\section{METODOLOGÍA}

En este apartado se detalla el método científico utilizado y una descripción de las distintas fases de investigación necesarias para intentar responder las preguntas de investigación formuladas.

\subsection{UNIVERSO Y MUESTRA}

Latindex es un sistema de información sobre las revistas de investigación científica, técnico-profesionales y de divulgación científica y cultural que se editan en los países de América Latina, el Caribe, España y Portugal. Creado en 1995 en la Universidad Nacional Autónoma de México (UNAM). Se ha optado por el Directorio de Latindex para delimitar nuestro universo de búsqueda ya que es una fuente de referencia que incluye más revistas científicas que otras bases de datos más restrictivas, como Scopus, de Elsevier, o Social Sciences Citation Index (SCI), de Thomson Reuters. Unos índices que reducirían lo suficientemente inclusiva y representativa de la región de estudio (España) como para no limitar la aparición de artículos en nuestra materia y, por ende, los potenciales resultados de nuestra investigación.

En marzo de 2016 el Directorio de Latindex contaba con un total de 24.488 revistas indexadas, repartidas entre todas las especialidades del conocimiento y todos los países participantes. Aquellas revistas que contaban a la vez con una versión impresa y otra electrónica eran contabilizadas por separado por el sistema, ya que poseían un ISSN distinto.

Se utilizó la opción de Búsqueda Avanzada del Directorio de Latindex para acotar la búsqueda al ámbito concreto de Ciencias de la Comunicación y a las fronteras geográficas de España, que dio como resultado 77 revistas; que terminaron siendo 65 tras unificar aquéllas que contaban con versión impresa y electrónica y eliminar una que aparecía repetida: Área Abierta.

Posteriormente se accedió a las webs corporativas de las revistas para realizar un estudio longitudinal. Cuando éstas no ofrecieron suficiente información, también se usaron bases de datos en línea de referencia, como Dialnet.

No se limitaron los años de la búsqueda, puesto que uno de nuestros objetivos era ver la evolución temporal del objeto de estudio. Por lo tanto, todas las revistas se analizaron desde su primer ejemplar hasta el más reciente, siendo la más antigua la revista Anàlisi (UAB, 1980).

Finalmente, las revistas constitutivas de la muestra a analizar fueron las siguientes [Ver Tabla I de ANEXOS]. 


\subsection{OBTENCIÓN DE LA MUESTRA}

Se analizaron los títulos, resúmenes y palabras clave de los 10.082 artículos que conformaban el universo de estudio con el objetivo de encontrar aquellos trabajos que incluyeran una serie de conceptos de búsqueda relacionados con las marcas de territorio y la diplomacia pública, ya que no existe un uso de términos constante ni común, por lo que fijar unas pocas variables exactas de búsqueda supone una importante limitación inicial para la investigación.

De todos modos, para facilitar la búsqueda y dotarla de validez científica, se seleccionaron una serie de palabras clave, previamente fijadas por expertos en cada una de las especialidades. Para fijar la búsqueda se optó por los términos clave en el estudio "Características y funciones para marcas de lugar a partir de un método Delphi" (San Eugenio et al., 2013): "branding", "branding de lugar", "destination branding", "destination marketing", "experiencia con el lugar", "identidad de lugar", "imagen de lugar", "marca", "marca de lugar", "marca de territorio", "marketing de lugar", "place branding", "place marketing" y "sentido de lugar".

Partiendo de la revisión bibliográfica, se añadieron las combinaciones posibles entre los conceptos "branding", "comunicación", "comunicación internacional", "gestión", "imagen", "identidad", "marca", "marketing", "percepción", "promoción", "relaciones públicas" y "reputación" con adjetivos como "turístico" y "territorial", y con sustantivos referentes a lugares y a sus gestores, como por ejemplo "Administración Pública", "ciudad", "DMO's", "estado", "nación", "pais", "región", e incluso los topónimos específicos de los lugares en cuestión.

Las palabras de búsqueda sobre trabajos en diplomacia pública se basaron en las conclusiones de la revisión bibliográfica internacional en diplomacia pública realizada por Oviamionayi (2004, p. 233-234), de las cuales se extrajeron los términos clave: "diplomacia", "diplomacia contemporánea", "diplomacia pública", "opinión pública", "política exterior", "público", "público extranjero", "élite" y "relaciones internacionales".

Del mismo modo, se optó por contemplar también la traducción de todas las palabras clave a otros idiomas.

Se limitó la búsqueda a artículos, investigaciones y estudios de caso, prescindiendo de otras entradas de las revistas de investigación, como editoriales, reseñas de libros $^{3}$, tesis doctorales ${ }^{4}$, agendas de actividades, etc.

Tras revisar una primera selección de artículos, se descartaron algunos títulos preseleccionados porque se relacionaban de un modo excesivamente secundario con nuestro objeto de estudio. Concretamente, se decidió eliminar de la muestra aquellos:

- Estudios sobre las imágenes que se dan de los inmigrantes en los medios.

- Estudios excesivamente genéricos sobre la comunicación internacional y/o las relaciones internacionales. Estudios excesivamente genéricos sobre la comunicación intercultural. Investigaciones demasiado genéricas sobre comunicación de la Administración Pública y de la ciudadanía. Trabajos centrados en la imagen de representantes específicos de la Administración, pero no en la imagen del territorio al que representan. Estudios que abordaban la comunicación territorial desde una vertiente intrapersonal de la comunicación, en tanto que entendemos que las marcas de territorio y la diplomacia pública estarían focalizadas en la vertiente interpersonal. Estudios sobre aspectos excesivamente concretos de la comunicación turística, alejados de las marcas de territorio y la diplomacia pública.

- Y artículos que aparentemente incluían palabras clave en los títulos, pero que tras leer los resúmenes se vio que no guardaban suficiente relación con la comunicación ni con la promoción territorial.

Las búsquedas sistemáticas para localizar los artículos que conformarían la muestra de la investigación se realizaron entre el 27 de febrero y el 3 de marzo de 2016.

\subsection{MÉTODO DE ANÁLISIS}

La metodología utilizada fue el análisis de contenidos (Berelson, 1952; Krippendorff, 2013; López Noguero, 2002), un método empírico-analítico que permite lograr los objetivos de investigación de un modo sistemático, objetivo y cuantitativo (Castillo y Carretón, 2010).

Para el análisis descriptivo de los artículos, se creó una plantilla ad hoc a la que, mediante un estudio longitudinal, se trasladaron diversas variables de identificación, autoría y temática. 


\section{RESULTADOS}

Una vez depurada la lista definitiva de artículos, se identificaron un total de 123 artículos que cumplían con los requisitos de búsqueda de entre el total de 15.082 artículos publicados en las 65 revistas españolas especializadas en Comunicación indexadas en Latindex, desde la fundación de la más antigua (Anàlisi, 1980) hasta el 3 de marzo de 2016 [Ver Tabla II de ANEXOS].

El análisis reveló que en las revistas Anuarios Thinkepi; Commons; Communication Papers; Conexiones; Dígitos, El Profesional de la Información; Etic@net; Eu-topías; Formats; IDP; Index; Infoamérica; Lengcom; Logo; Mediatika; Obra Digit@l; Pangea; Periodística; Redes.com; Boletín RedIRIS; Revista de Comunicación y Salud; Revista de la Asociación Española de Investigación en Comunicación (RAEIC); Revista Española de Comunicación en Salud; Revista Estudios Institucionales; Revista Internacional de Comunicación y Desarrollo; Revista Internacional de Historia de la Comunicación; Revista Internacional del Libro, Digitalización y Bibliotecas; Revista Mediterránea de Comunicación; y Teknokultura, no se publicó ningún artículo que cumpliese con el criterio de búsqueda de los parámetros fijados (hasta el 03.03.16). Por el contrario, sí se detectaron artículos que cumplían dichos parámetros en las revistas AdComunica; AdResearch; Ámbitos; Anàlisi; Área Abierta; Catalan Social Science Review; CIC Cuadernos de Información y Comunicación; Communication \& Society; Comunicació; Comunicación; Comunicación y Estudios Universitarios; Comunicación y Hombre; Comunicar; Derecom; Doxa; Estudios sobre el mensaje periodístico; Fonseca; Grafica; Historia y Comunicación Social; I/C; ICONO 14; La Comunicación empresarial y la gestión de los intangibles en España y Latinoamérica; Mediaciones Sociales; Miguel Hernández Communication Journal; Pensar la publicidad; Questiones Publicitarias; Revista de la SEECI; Revista Internacional de Relaciones Públicas; Revista Latina de Comunicación Social; Sphera Pública; Telos; Textual \& Visual Media; Trípodos; Vivat Academia; y ZER. Finalmente, desconocemos en qué categoría situar la revista Caleidoscopio, en tanto que no ha podido realizarse el análisis debido a no encontrar ningún sitio web ni directorio que incluyera algún tipo de información acerca de sus artículos publicados.

Así, el 53,8\% de revistas (35) publicó artículos que cumplían con los requisitos de búsqueda, mientras que el $46,2 \%$ restante (30) no lo hizo. Asimismo, se observa que cada una de las 65 revistas analizadas publicó un promedio de 1,9 artículos con temáticas relacionadas con las marcas de territorio y la diplomacia pública.

La revista más activa a nivel de publicaciones sobre nuestro objeto de estudio fue Historia y Comunicación Social, con 16 artículos que cumplían los criterios de búsqueda (un 13\% del total de 123). La segunda posición le correspondió a Communication \& Society $(8-6,5 \%)$ y la tercera la Revista Latina de Comunicación Social $(7-$ 5,7\%). Empatadas a 5 publicaciones (4,1\%) encontramos hasta 7 revistas: Comunicación; Comunicar; Estudios sobre el mensaje periodístico; Pensar la publicidad; Questiones publicitarias; Revista Internacional de Comunicación y Publicidad; y Revista Internacional de Relaciones Públicas. A continuación, se encontraron 4 revistas empatadas a 4 publicaciones por cabeza (I-C; Revista de la SEECI; Telos; y Trípodos), seguidas de hasta 6 cabeceras que coexistían con 3 artículos publicados (Anàlisi; Área Abierta; Comunicación y Estudios Universitarios; Fonseca; ICONO 14; y ZER), y 8 revistas que contaban con 2 publicaciones cada una (AdComunica; AdResearch; Ambitos; CIC; Comunicació; Comunicación y Hombre; Sphera Pública; y Textual \& Visual Media). Finalmente, se revelaron 7 revistas que únicamente publicaron un único artículo sobre marcas de territorio y diplomacia pública: Catalan Social Sciences Review; Derecom; Doxa; Grafica; La comunicación empresarial y la gestión de los intangibles en España y Latinoamérica; Mediaciones Sociales; y Miguel Hernández Communication Journal.

Los 123 artículos que cumplieron los requisitos de búsqueda fueron escritos por 149 autores distintos ${ }^{5}$, de los cuales 69 (el 46,3\%) eran hombres y 79 (el 53\%) eran mujeres. Mayoritariamente el número promedio de autores por artículo se situaba en torno a 1,5 [Ver Tabla III de ANEXOS].

Si bien la mayoría de autores (125 - 83\%) sólo publicaron un artículo que cumpliera los requisitos de búsqueda, una serie de autores (25 - 17\%) lo hicieron en más de una ocasión: Jordi de San Eugenio (5) José Fernández-Cavia (5), Mónica Matellanes Lazo (5), Assumpció Huertas (3), Juan Luis Manfredi Sánchez (3), Noelia Araújo Vila (2), Miguel-Ángel Chaves Martín (2), Beatriz Correyero Ruiz (2), Gema Cano Jiménez (2), Juan Manuel Corbacho Valencia (2), Francisco Cabezuelo-Lorenzo (2), Pablo Díaz-Luque (2), Trinidad Domínguez Vila (2), María Dolores Fernández Poyato (2), Blanca García Henche (2), Manuel Garrido Lora (2), Xavier Ginesta Portet (2), Monika Jiménez-Morales (2), María Teresa La Porte Fernández-Alfaro (2), María Isabel Míguez González (2), Joan Nogué (2), Miguel Ángel Ortiz Sobrino (2), Eva Marina Reinares Lara (2), Alfredo Rodríguez Gómez (2) y Mónica Valderrama Santomé (2). 
En lo referente a la afiliación de los autores, en 18 ocasiones los artículos consultados no han mostrado la institución de procedencia del autor, por lo que el análisis de esta variable deberá ser tomada de un modo orientativo. Tras revisar los 123 artículos se detectaron 54 instituciones representadas, 35 de ellas españolas y otras 19 extranjeras. De dichas instituciones, 53 correspondían a universidades y 1 a una fundación (la Fundación de Cultura Ciudad de Cuenca). Las universidades que contaban con más afiliaciones fueron éstas: Vigo (16), Complutense de Madrid (14), Pompeu Fabra de Barcelona (13), Sevilla (9), Vic (8), Valladolid (7) ${ }^{6}$, Málaga (6), Navarra (6) y País Vasco (6); CEUSan Pablo (5), Europea Miguel de Cervantes de Valladolid (5), La Laguna (5), Alicante (4), Autónoma de Barcelona (4), Carlos III de Madrid (4), Rey Juan Carlos (4), Rovira i Virgili (4), Salamanca (4), Jaume I (3), Alcalá (2), Camilo José Cela (2), Castilla-La Mancha (2), Francisco de Vitoria (2), Girona (2), Pablo de Olavide (2), Santiago de Compostela (2), Valencia (2), Católica de Chile (2), Piura (2), IE Segovia (1), Internacional de Cataluña (1), Lleida (1), Murcia (1), Nacional de Educación a Distancia (1), Pontificia de Salamanca (1), San Jorge (1), Amberes (1), los Andes (1), Coimbra (1), Emerson College de Boston (1), Federal de Rio de Janeiro (1), Glasgow (1), Económicas de Izmir (1), Lun (1), Nice Sophia-Antipolis (1), Peruana de Ciencias Aplicadas (1), Sofocaba de São Paulo (1), Sud Toulon-Var (1), Technological Educational Institute de Creta (1), Texas (1), Toulousse III (1) y Udine (1).

Según datos publicados por el Ministerio de Educación, Cultura y Deporte de España (2015, p. 5), en el curso 2014-2015 el Sistema Universitario Español (SUE) contaba con 83 universidades, 50 públicas y 33 privadas. El hecho de encontrar 35 universidades españolas, públicas y privadas, con temáticas relacionadas con las marcas de territorio y la diplomacia pública, parece indicar que estamos frente a un área de investigación recurrente en un gran número de instituciones del país. Concretamente, en un 42,2\% $(n=83)$ de las universidades. Porcentaje que probablemente aumentaría si contemplásemos exclusivamente aquellas instituciones que cuentan con una oferta formativa en Ciencias de la Comunicación.

No únicamente son heterogéneos los autores y las universidades, sino también las Comunidades Autónomas (CC.AA.) a las que pertenecen. Se encuentran representadas 12 de las 17 CC.AA. que conforman el entramado administrativo español (70,6\% del total). Además, destaca la Universidad de Educación a Distancia que, a pesar de contar con sede en Madrid, es de ámbito estatal (ver <www.uned.es $>$ ).

Las CC.AA. con más actividad investigadora en temática de marcas de territorio y diplomacia pública fueron Cataluña (7), Comunidad de Madrid (7), Castilla y León (5), Andalucía (3), Comunidad Valenciana (3), Galicia (2), Aragón (1), Castilla-La Mancha (1), Islas Canarias (1), Región de Murcia (1), Comunidad Foral de Navarra (1) y País $\operatorname{Vasco}(1)$.

El liderazgo compartido de Cataluña y la Comunidad de Madrid es coherente con la cantidad de universidades que acogen dentro de sus fronteras: 12 y 15 respectivamente (Ministerio de Educación, Cultura y Deporte de España, 2015 , p. 6). Sin embargo, el porcentaje de universidades catalanas que trabajan temáticas relacionadas con las marcas de territorio y la diplomacia pública es ligeramente superior al de sus homónimas madrileñas: 58,3\% y 46,6\%, respectivamente. La jerarquía de universidades andaluzas, castellano-leonesas y valencianas también es acorde al número total de universidades que hospedan (11, 9 y 9 respectivamente): un 55,6\% de las universidades de Castilla y León habrían investigado la comunicación y promoción territorial, por un $27,3 \%$ de las andaluzas y un $33,3 \%$ de las valencianas. Finalmente, han trabajado esta línea de investigación 2 de las 3 universidades existentes en Galicia (66,6\%); 1 de las 2 aragonesas (50\%); 1 de 1 en Castilla y La Mancha (100\%); 1 de 4 en las Islas Canarias (25\%); 1 de 3 en la Región de Murcia (33,3\%); 1 de 2 en la Comunidad Foral de Navarra (50\%); y 1 de 3 en el País Vasco $(33,3 \%)$.

De las 19 universidades no españolas presentes en los 123 artículos analizados, apunta un ligero dominio de las instituciones europeas (10 - 52,6\%), aunque seguidas muy de cerca por las americanas (9 - 47,4\%). De Europa, Francia es el país, aparte de España, del cual proceden un mayor número de investigadores: 3. Le siguen otros 7 países, empatados a 1 afiliación cada uno: Italia, Portugal, Reino Unido, Bélgica, Suecia, Grecia y Turquía. En el continente americano, Estados Unidos encabeza la lista con 3 representaciones, seguido de Chile, Perú y Brasil, con 2.

Los 123 artículos detectados sobre marcas de territorio y diplomacia pública se publicaron en fechas comprendidas entre 1987 y 2016. Los años más activos a nivel de publicaciones fueron, de mayor a menor, 2014 (con 20 artículos y un 16,3\% del total publicado); 2013 (18 - 14,6\%); 2010 (16 - 13\%); 2012 (12 - 9,8\%); 2009 (10 - 8,1\%); 2007 (7 $5,7 \%) ; 2015(5-4,1 \%) ; 1998,1999$ у 2002 (4-3,3\%); 2001 у 2006 (3-2,4\%); 1996, 2004, 2005, 2008 у 2011 (2$1,6 \%)$; у 1987, 1989, 1990, 1992, 2000, 2003 у 2016 (1-0,8\%). 
Sobre las lenguas utilizadas en la publicación de los 123 artículos que cumplieron con los parámetros de búsqueda, la castellana se presenta como la más usada en un $85,4 \%$ de los casos (105). Le siguen el inglés $(9-7,3 \%)$, el catalán $(4-3,3 \%)$, el francés $(3-2,4 \%)$ y el portugués $(2-1,6 \%)$.

Por medio del análisis de contenidos se comprobó que los temas principales de los títulos de los artículos de las revistas en el periodo de análisis eran múltiples y de muy diversa etiología. El mayor número de títulos de artículos (21 casos - 17,1\%) (a) estaba relacionado con el tratamiento y cobertura mediáticos de identidades nacionales [Ver Tabla IV de ANEXOS]. Le siguieron (b) aquellos estudios sobre la imagen percibida -reputación- de un territorio (17 - 13,8\%) -concebido en la mayoría de casos como destino turístico-; (c) los trabajos que trataron el impacto de internet en las marcas de destino, de territorio y en diplomacia pública $(13-10,6 \%)$; y (d) los artículos que teorizaron sobre la diplomacia pública, sus tipologías y características $(11-8,9 \%)$. En un siguiente grupo de entre 6 y 10 representaciones por temática, encontramos los artículos (e) focalizados en el análisis de las acciones de promoción turística por parte de los destinos $(7-5,7 \%)$; (f) los que se centraron en la gestión de las marcas de territorio (6 $4,9 \%)$; y (g) los que estudiaron las estrategias de promoción turística en contextos específicos $(6-4,9 \%)$-ejemplo: enoturismo, turismo cultural...-. Finalmente, encontramos varias temáticas escasamente representadas, como (h) la creación de marcas de territorio a partir de marcas comerciales y el efecto "made in"; (i) las estrategias de comunicación en diplomacia pública y en relaciones internacionales; (j) la representación de imágenes y estereotipos territoriales en la educación, en el deporte o a través de las ONG; (k) la historia de la diplomacia pública y de las marcas de destino; (1) las políticas de comunicación para la construcción de identidades nacionales o supranacionales; (m) las Políticas Públicas en la creación de clusters turísticos; (n) los atributos de la construcción de marca de territorio; (o) las marcas de territorio contempladas desde el derecho de la comunicación; ( $p$ ) la comunicación turística y la interculturalidad, etc. [Ver Tabla IV de ANEXOS].

De las 123 investigaciones publicadas, (1) el análisis del contenido se presentó como la metodología más frecuente en un 34,1\% de los casos (42). Le siguieron los artículos que fueron considerados: (2) ensayos y/o revisiones bibliográficas o documentales 40 (32,5\%). A una distancia considerable se detectaron (3) el método del estudio de caso, presente en al menos 8 artículos (6,5\%) -dos de ellos basados en la Teoría del Framing-; (4) las entrevistas cualitativas $(7-5,7 \%)$-la mayoría en profundidad-; (5) los cuestionarios cerrados y/o encuestas $(7-5,7 \%)$; $(6)$ y aquellos artículos que se autodefinían como análisis descriptivo $(5-4,1 \%)$; (7) observación participante $(2-1,6 \%)$ y (8) análisis comparativo $(2-1,6 \%)$. Concluirían el listado aquellos métodos que sirvieron como base a 1 único artículo $(0,8 \%)$ cada uno, a saber: (9) el grupo focal de discusión o focus group; (10) el método Delphi; (11) el método basado en la escala de Likert; (12) el método iconográfico/iconológico; (13) el análisis crítico; (14) el análisis con datos secundarios; (15) el análisis diacrónico del relato; (16) el análisis de información; (17) el análisis documental; (18) el análisis de la interactividad; (19) el análisis de la visibilidad; (20) el análisis del posicionamiento web en buscadores; (21) el análisis del éxito; (22) el análisis del perfil de usuarios; (23) el análisis inductivo; (24) el análisis del juego simbólico; el análisis formal; (25) el análisis fundamentado en la Teoría de la Enunciación; (26) el análisis fundamentado en la Teoría del Enfoque; (27) el análisis fundamentado en la Teoría de la Reputación; (28) el análisis jurídico; (29) el estudio etnológico; (30) el estudio histórico; (31) el estudio piloto; y (32) la prueba experimental de modificación de webs.

Las muestras de estudio que se emplearon fueron de diversa índole. Distinguimos las siguientes categorías:

- Literatura, informes y otros documentos considerados datos secundarios $(45-36,6 \%)$;

- Datos primarios documentales, como la correspondencia entre individuos $(1-0,8 \%)$;

- Acciones de política exterior en general $(2-1,6 \%)$;

- Contenidos informativos publicados en los medios:

a) Noticias $(3-2,4 \%)$,

b) Fotografías $(3-2,4 \%)$,

c) Discursos políticos $(2-1,6 \%)$,

d) Portadas $(1-0,8 \%)$;

- Contenidos promocionales publicados en los medios:

a) Campañas enteras de publicidad $(7-5,7 \%)$-la gran mayoría de promoción turística-,

b) Únicamente los anuncios de televisión $(1-0,8 \%)$;

- Expertos en marcas de territorio $(1-0,8 \%)$ u otros ámbitos de interés para la investigación $(1-0,8 \%)$;

- Marcas de territorio específicas $(2-1,6 \%)$;

- Destinos turísticos en general $(1-0,8 \%)$ y sus responsables de comunicación en particular $(3-2,4 \%)$;

- Iconos concretos dentro de un destino turístico ( $1-0,8 \%)$;

- Públicos de las marcas de territorio y/o la diplomacia pública

a) Turistas $(6-4,9 \%)$, 
b) Residentes en general $(3-2,4 \%)$ o pertenecientes a comunidades étnicas concretas en particular (1 $0,8 \%$ ),

c) Empresas especializadas en el sector turístico $(3-2,4 \%)$,

d) Empresarios $(1-0,8 \%)$,

e) Representantes políticos $(1-0,8 \%)$ y otros funcionarios de la Administración Pública (1 - 0,8\%),

f) Líderes de opinión $(1-0,8 \%)$,

g) Actores de referencia de la sociedad civil $(1-0,8 \%)$,

h) Estudiantes foráneos $(1-0,8 \%)$;

- Soportes comunicativos determinados
a) Películas de cine $(10-8,1 \%)$,
b) Periódicos $(9-7,3 \%)$,
c) Sitios web $(9-7,3 \%)$,
d) Redes sociales $(4-3,25 \%)$,
e) Cadenas de televisión en general $(1-0,8 \%)$ o sus programas concretos en particular $(1-0,8 \%)$,
f) Emisoras de radio $(1-0,8 \%)$,
g) Revistas $(1-0,8 \%)$,
h) Banners $(1-0,8 \%)$,
i) Dispositivos móviles $(1-0,8 \%)$,
j) Sellos y billetes $(1-0,8 \%)$,
k) Libros de texto $(1-0,8 \%)$.

Referente a los territorios que resultaron objeto de estudio en las investigaciones analizadas, se observa que 21 $(17,1 \%)$ de ellas no estudiaron ningún territorio específico, sino que se trataba de ensayos o revisiones bibliográficas que hablaban sobre las marcas de territorio y la diplomacia pública en el mundo en general. El 82,9 \% restante (102) sí fueron estudios que trataron algún tipo de ente territorial. Unos entes que dividiremos, a su vez, en cuatro niveles, de mayor a menor dimensión conceptual: (1) Entes supranacionales y transnacionales, (2) Entes estatales, (3) Entes regionales y sub-regionales, y (4) Entes municipales.

En el primer nivel encontramos 6 estudios (4,9\%) que hacían referencia a entes territoriales supranacionales, como Europa en general (2), la Unión Europea en particular (2), el "Mundo árabe” en general (1) y el "Tercer Mundo" (1). En este mismo nivel también podríamos incluir otros 2 estudios $(1,6 \%)$ focalizados en regiones transnacionales, concretamente los Países Catalanes -que incluyen Cataluña, Valencia, Baleares y la Cataluña Norte, repartidos entre España y Francia- y la región de Öresund -compartida entre Dinamarca y Suecia-.

El segundo nivel, conformado por el 41,5\% de los artículos analizados (51), incluiría aquellas investigaciones que tomaron como objeto de estudio la figura territorial del Estado. En esta categoría, el más representado fue el Estado español, con 30 artículos (un 58,8\% del total de estudios estatales). Le siguieron Estados Unidos de América con 8 $(15,7 \%)$; Brasil, Chile, Francia, Grecia y Suecia con 2 (lo que equivale a una representación del 3,9\% por país); y concluyen el listado Alemania, Bélgica, Haití, Japón, Libia, México, Paraguay, Perú, Polonia, Qatar, República Dominicana, Suiza y Tailandia, con 1 (un $2 \%$ por país).

El tercer nivel sería el de los artículos sobre subdivisiones regionales ( 33 - 26,8\%), que incluiría entes territoriales como las Comunidades Autónomas (con 25 artículos diferenciados, lo que equivaldría a un 75,8\% dentro de este tercer nivel territorial), las provincias $(1-3 \%)$, las comarcas $(4-12,1 \%)$, las regiones turísticas $(1-3 \%)$ y las regiones naturales $(2-6,1 \%)$.

En lo referente a los estudios sobre las Comunidades Autónomas (CC.AA.) españolas, Andalucía lideraría un hipotético ranking con 11 artículos que la contemplan como objeto de estudio, seguida de Cataluña (6), Castilla y León (5), Islas Canarias (5), Comunidad Valenciana (4), La Rioja (3), Galicia (2), Comunidad Foral de Navarra (2) y el País Vasco (2). Cerrarían el listado, empatadas a una única representación, Aragón, Asturias, Islas Baleares, Cantabria, Castilla-La Mancha, Ceuta, Extremadura, Comunidad de Madrid, Melilla y Región de Murcia.

A nivel provincial español, empatan, con una única representación cada una, Álava, Albacete, Alicante, Almería, Asturias, Ávila, Badajoz, Barcelona, Burgos, Cáceres, Cádiz, Castellón, Ciudad Real, Córdoba, La Coruña, Cuenca, Girona, Granada, Guadalajara, Guipúzcoa, Huelva, Huesca, Jaén, León, Lleida, Lugo, Málaga, Orense, Palencia, Las Palmas, Pontevedra, Salamanca, Segovia, Sevilla, Soria, Tarragona, Santa Cruz de Tenerife, Teruel, Toledo, Valencia, Valladolid, Vizcaya, Zamora y Zaragoza. 
A escala comarcal, se detectan 4 estudios focalizados en dos únicas comarcas: Ribera del Duero (3) y Priorat (1), ambas regiones vinícolas de gran importancia a nivel estatal. Por regiones turísticas que no existen a nivel político encontramos un artículo que tomó la "Costa Blanca", la marca turística de las playas de Alicante, como objeto de estudio. Por regiones naturales, identificamos dos artículos: uno se centró en la reserva indígena de los Malekus (Costa Rica) y otro lo hizo en el Parque Nacional de las Cinco Tierras (Italia).

Tras el nivel de subdivisiones regionales, distinguimos un cuarto y último nivel centrado exclusivamente en las ciudades. Se detectaron 59 ciudades (52 españolas y 7 de otros países) repartidas en 15 artículos diferenciados, los cuales representan un $12,2 \%$ del total de estudios analizados.

Encabezaron las ciudades españolas Barcelona y Madrid, con 5 y 4 representaciones respectivamente. Empatadas a 3, les siguieron Las Palmas de Gran Canaria, Santiago de Compostela y Valencia; y a 2, Bilbao, Cuenca, Granada, Lugo, Málaga, Murcia, Ourense, Palma de Mallorca, San Sebastián, Segovia, Sevilla, Santa Cruz de Tenerife, Valladolid y Zaragoza. Cerraron la clasificación, con una única representación cada una, las ciudades de Albacete, Alicante, Almería, Oviedo, Ávila, Badajoz, Burgos, Cáceres, Cádiz, Santander, Castellón de la Plana, Ciudad Real, Córdoba, La Coruña, Girona, Guadalajara, Huelva, Huesca, Jaén, León, Lleida, Pamplona, Palencia, Pontevedra, Logroño, Salamanca, Soria, Tarragona, Teruel, Toledo, Bilbao, Zamora y Vitoria.

Las 7 ciudades no españolas fueron Brujas, Dublín, Londres, Nueva York, París, Quebec y Toronto. Todas ellas con una única representación.

En las palabras clave de los artículos, se observa que los términos utilizados son muy abundantes y diversos. El que se cita mayor número de veces es “comunicación" (30 en castellano y 4 en inglés, apareciendo en un $27,6 \%$ del total de artículos analizados). Las siguientes posiciones en el ranking, todas con un mínimo de 5 citaciones en el apartado de palabras clave, las ocupan los términos "turismo" (25 en castellano + 1 en inglés, 21,1\%); "marca" (18 14,6\%); "imagen" (16 en castellano + 2 en inglés, 14,6\%); "publicidad" (14 - 11,4\%); "identidad" (11 en castellano + 1 en inglés, 9,75\%); "marketing" (11 - 8,9\%); "ciudad" (6 veces en castellano + 4 en inglés, 8,1\%); "España" (9 $7,3 \%)$; "relaciones públicas" (7 en castellano + 1 en inglés, 6,5\%); "estrategia" (7 - 5,7\%); "branding" (7 - 5,7\%); "territorio" (7 - 5,7\%), "politica" (7 - 5,7\%); “web" (7 - 5,7\%); “diplomacia pública" (6 - 4,9\%); "estereotipos" (6 4,9\%); "redes sociales" (5 - 4,1\%) y "marca de territorio" (5 - 4,1\%).

Dichos términos no siempre aparecen solos, sino que en muchas ocasiones forman parte de palabras compuestas. Por ejemplo, en el caso del término "comunicación", el más representado en el ranking de palabras clave -hasta en 28 ocasiones- aparecía ligado a otros vocablos, como: "comunicación internacional” (3), "comunicación turística" (3), "estrategia de comunicación" (3), "medios de comunicación" (3), "comunicación política" (2), "comunicación institucional" (2), "comunicación y ciudad" (1), "comunicación de gobierno" (1), "comunicación de la gestión pública" (1), "comunicación corporativa" (1), "comunicación de masas" (1), "política de comunicación" (1), "comunicación mercadotécnica" (1), "plan estratégico de comunicación integral" (1), "comunicación 2.0" (1), “comunicación coordinada" (1), “derecho de la comunicación" (1) e "historia de la comunicación" (1).

El siguiente término más representado en las palabras clave, "turismo", se localizó en 12 ocasiones en palabras compuestas como "enoturismo" (5), "turismo rural" (2), "turismo 2.0" (1), "turismo cultural" (1), "e-turismo" (1), "periodismo de turismo y viajes" (1) y "cine y turismo" (1).

"Marca", el tercer vocablo más repetido en las palabras clave, también aparecía en expresiones compuestas como “marca (de) territorio" (5), "marca país" (3), "marca de destino" (3), "Marca España" (3), "imagen de marca" (2), “marca de lugar" (1), "marca turística" (1), "gestión de la marca” (1), "alianza de marca" (1) “Marca Perú" (1).

El cuarto término del ranking, "imagen", se asociaba a su vez a los conceptos "imagen de país" (1), "imagen turística de un territorio" (1), "imagen turística" (1), "imagen del destino" (1), "imagen del Estado" (1), "imagen cultural" (1), "imagen de marca" (1), "imagen corporativa" (1), "imagen positiva" (1), "gestión de la imagen" (1) e "imagen de España" (1).

Y así podríamos seguir con todos los siguientes términos, únicamente para comprobar que las combinaciones posibles son muy abundantes. 


\section{DISCUSIÓN Y CONCLUSIONES}

Vista la ausencia de estudios bibliométricos sobre marcas de territorio y diplomacia pública en España, este artículo pretende servir como punto de partida para futuros estudios sobre ambas disciplinas que busquen conocer el estado de la cuestión de estas áreas del conocimiento, partiendo de una base científica sólida y una revisión bibliográfica exhaustiva de las publicaciones de la muestra analizada.

De igual modo, el estudio bibliométrico realizado nos ha permitido responder a la totalidad de las preguntas de investigación iniciales.

En primer lugar, se observa que aproximadamente 1 de cada 100 de artículos publicados en las revistas españolas especializadas en Comunicación indexadas en Latindex han tratado temáticas relacionadas con las marcas de territorio y la diplomacia pública (PI1).

En lo relativo a las fechas de publicación (PI2), domina claramente la segunda década del siglo XXI en un 60,2\% de casos, a pesar de que en el momento de realizar el estudio sólo se había podido contabilizar su primer lustro. Por lo tanto, podría afirmarse que, al menos en España, las marcas de territorio y la diplomacia pública son un campo de investigación de gran actualidad. Asimismo, el hecho que los cinco años más activos a nivel de publicaciones fueran, de mayor a menor, 2014, 2013, 2010, 2012 y 2009 indica que se trata de un campo de estudio que sigue en constante crecimiento, prácticamente ininterrumpido y con pocos altibajos. Se observa una evolución muy marcada a través de las últimas cuatro décadas, con un inicio muy tímido en los años ' 80 del siglo XX $(1,6 \%)$; un asentamiento progresivo en los '90 (9,8\%); una consolidación en la primera década del siglo XX $(28,3 \%)$ y una explosión definitiva a partir de 2010.

El 46,3\% de los autores fueron hombres y el 53\%, mujeres (PI3). Unos porcentajes congruentes con los presentados por Castillo et al. (2012, p. 261) en su análisis de las revistas ISI españolas especializadas en Comunicación, donde observaban que la participación de hombres y mujeres era cada vez más uniforme, con porcentajes de género cercanos al $50 \%$.

Si bien destacó una alta heterogeneidad en las autorías, se identificaron cinco autores especialmente activos en la investigación de marcas de territorio y diplomacia pública (PI4): Jordi de San Eugenio, José Fernández-Cavia, Mónica Matellanes Lazo, Assumpció Huertas y Juan Luis Manfredi Sánchez; un 60\% de los cuales procedía de instituciones catalanas, mientras que el $40 \%$ restante mantenía vínculos con universidades castellano-leonesas y castellanomanchegas (P15).

Lo más frecuente fue encontrar artículos escritos por un único autor en un $65,8 \%$ de los casos (PI6), porcentaje muy parecido al $66,7 \%$ obtenido por Baladrón-Pazos et al. (2014). También se localizaron trabajos donde colaboraron hasta 8 investigadores, apuntando tal vez una tendencia progresiva a la colaboración interinstitucional e internacional. Finalmente, se obtuvo una media que oscilaba entre los 1,5 autores por artículo, unos datos muy similares a los obtenidos por Castillo et al. (2012, p. 261).

Las marcas de territorio y la diplomacia pública se presentaron como un área de investigación recurrente en un $42 \%$ de las universidades españolas y en un $70 \%$ de las Comunidades Autónomas, mostrando un alto índice de penetración institucional y geográfica. Las regiones más productivas a nivel académico fueron Cataluña, la Comunidad de Madrid, Castilla y León, Andalucía y la Comunidad Valenciana, si bien las cinco universidades más representadas fueron la de Vigo, la Complutense de Madrid, la Pompeu Fabra de Barcelona, la de Sevilla y la de Vic (PI7).

Más de la mitad $(53,8 \%)$ de las revistas españolas especializadas en Comunicación publicaron, por lo menos, un artículo sobre marcas de territorio y diplomacia pública hasta marzo de 2016, aunque fueron 3 las cabeceras que más activas se mostraron en este sentido: Historia y Comunicación Social, Communication \& Society y Revista Latina de Comunicación Social (PI8), editadas en Madrid, Pamplona y Tenerife, respectivamente (PI9). Ninguna de las tres revistas explicitaba las marcas de territorio y la diplomacia pública como áreas de especialización en sus webs corporativas, si bien sí que proponían unas temáticas lo suficientemente amplias como para que ambas especialidades pudieran incluirse (ejemplo: Historia de los Medios de Comunicación, Relaciones Públicas, Comunicación, Comunicación Social, etc.). 
Las 10 palabras clave más utilizadas (PI10) resultaron ser: "comunicación", "turismo", "marca", "imagen", "publicidad", "identidad", "marketing", "ciudad", "España" y "relaciones públicas". En el análisis de palabras clave se corroboró la falta de unanimidad terminológica identificada en el marco teórico, la cual provocó una gran heterogeneidad de conceptos aparentemente distintos que, sin embargo, en la mayoría de casos no eran tales. También se advierte un claro predominio de la concepción turística de la marca de territorio, una realidad acorde con la práctica actual de la profesión en España (Alameda y Fernández, 2012, p. 25). Finalmente, señalamos la ausencia generalizada del concepto "reputación", que únicamente aparece como palabra clave de uno de los 123 artículos analizados. En este sentido, se observa que el concepto "imagen" habría substituido erróneamente al de reputación, en inconsistencia con la definición de Fombrun y Shanley (1990, Cfr. Passow et al., 2005, p. 311): "as opposed to image, reputation is a strategic concept centered on long-term impressions of the organization built around numerous corporate images and actions".

Se identificaron siete grandes temáticas (PI11) que se repetían en un $66 \%$ de los artículos y en las cuales prevalecía también el componente turístico: (1) el tratamiento y cobertura mediáticos de identidades nacionales; (2) la imagen percibida de un territorio; (3) el impacto de internet en las marcas de destino, de territorio y en diplomacia pública; (4) la teorización sobre la diplomacia pública, sus tipologías y características; (5) las acciones de promoción turística por parte de los destinos; (6) la gestión de las marcas de territorio y (7) las estrategias de promoción turística en contextos específicos. En definitiva, se advierte un predominio de los acercamientos marketinianos al objeto de estudio, en consonancia con afirmaciones anteriores de expertos en comunicación y promoción de territorios, como Huertas (2014).

En cuanto a los idiomas utilizados (PI12), el 85,4\% de los artículos se publicó en castellano, seguido del inglés $(7,3 \%)$, el catalán $(3,3 \%)$, el francés $(2,4 \%)$ y el portugués $(1,6 \%)$. Unos datos que no son consistentes con los de Baladrón-Pazos et al. (2014), quienes en su estudio de las revistas científicas españolas especializadas en Comunicación de 1980 a 2013 criticaban la baja representatividad del inglés (1,4\% de su total analizado), el portugués $(0,6 \%)$ y el francés $(0,4 \%)$. Si bien la falta de internacionalización se hace evidente en ambos estudios, es cierto que en nuestros resultados se observan unas proporciones levemente mayores, especialmente en cuanto al inglés se refiere, por lo que podría especularse que, tal vez, los estudios que tratan la comunicación y promoción internacional de los territorios tiendan a buscar audiencias no castellano-parlantes que los focalizados en otros campos de investigación.

Los territorios geográficos objeto de estudio también fueron de muy diversa índole, si bien dominaron los que se encontraban dentro de las fronteras españolas (PI13), unos resultados consistentes con los obtenidos por Zugasti Azagra (2013) en las revistas IN-RECS que trataron temáticas de Historia de la Comunicación. Asimismo, la figura específica del Estado español fue estudiado por 1 de cada 4 artículos publicados, mientras que a nivel de regiones, Andalucía fue la más representada, copando el $9 \%$ del total de las investigaciones. Lo realmente destacable de esta variable es la alta representatividad de todas las comunidades autónomas, provincias y capitales de provincia en los estudios analizados, demostrando el creciente interés por estudiar todos los rincones del país.

La técnica metodológica más utilizada fue el análisis del contenido en un 34,1\% de los casos (PI14), un porcentaje prácticamente idéntico al 35,5\% obtenido en el estudio bibliométrico de las revistas IN-RECS realizado por Castillo y Carretón (2010). Sorprende que aproximadamente un 37\% de los artículos careciera de una metodología definida, unos datos consistentes con los de Castillo y Carretón (2010), quienes destacaban en su análisis bibliométrico que un $24 \%$ de los estudios no especificase método científico alguno. También los porcentajes de investigaciones fundamentadas en entrevistas semi-estructuradas, encuestas y observación participante fueron similares a los de dicho estudio de 2010, todos ellos inferiores al $10 \%$ del total.

Finalmente, destacamos que aproximadamente 1 de cada 10 artículos examinados trataron directamente la influencia de internet y las redes sociales en ambas especialidades (PI15). De este modo, entendemos que la comunicación digital podría considerarse como tendencia probable de un sub-campo de estudio de pleno derecho dentro de las marcas de territorio y la diplomacia pública.

\subsection{LIMITACIONES Y FUTURAS LÍNEAS DE INVESTIGACIÓN}

La primera limitación de la investigación fue que, si bien se leyó la versión completa de los artículos seleccionados en la mayoría de los casos, en aquellas ocasiones en las que no se disponía de acceso al documento completo, hubo que tomar exclusivamente como referencia el título, el resumen del artículo y las palabras clave. En tales circunstancias, por lo general se encontró suficiente información para responder a las variables de análisis, por lo que no ha sido una limitación de peso que haya imposibilitado avanzar en la investigación. Sin embargo, entendemos que 
hubiera sido más oportuno disponer siempre de todos los textos completos para el logro de unos resultados más contrastados.

Este estudio ha tenido un carácter eminentemente descriptivo, siendo recomendadas investigaciones posteriores de naturaleza más explicativa. Asimismo, cabe recordar que las fuentes consultadas fueron exclusivamente de ámbito nacional (revistas españolas de comunicación indexadas en Latindex), por lo que resulta imposible valorar la producción científica de los autores españoles en revistas fuera de sus propias fronteras y, por ende, la verdadera capacidad de internacionalización de la investigación de marcas de territorio y diplomacia pública en España, que debería ser objeto de estudios complementarios para la obtención del mapa completo y que nos proponemos acometer en un futuro cercano.

Teniendo en cuenta que para obtener una producción científica de mayor calidad es importante realizar análisis bibliométricos con cierta periodicidad (Castillo y Carretón, 2010), los autores tienen la intención de repetir este estudio sobre las revistas españolas objeto de estudio cada cinco años, con el objetivo de fijar su evolución y detectar posibles nuevas tendencias en la investigación de este área del conocimiento. Dichos estudios podrán ser de utilidad, también, para comprobar si el ritmo de crecimiento en la producción investigadora se mantiene a un nivel tan alto como el actual, o si por el contrario, se trata de un fenómeno puntual.

Por último, los autores pretenden replicar esta investigación a otros países en un futuro próximo, con la intención de efectuar estudios comparativos.

\section{NOTAS}

${ }^{1}$ Ver Oliveira (2016) para una mejor comprensión del concepto "públicos".

${ }^{2}$ Para profundizar en torno a la evaluación y la medición, ver Cuenca-Fontbona (2016) y Marca-Francés (2016).

${ }^{3}$ Si bien no hemos contabilizado las reseñas como universo del estudio, sí hemos podido observar algunas reseñas en revistas que hacían referencia a las marcas de territorio y a la diplomacia pública, como por ejemplo: "La imagen de España en Marruecos" de Affaya \& Guerraqui, publicada por la revista Comunicación (2006, vol. 4); "Diplomacia Pública y Place Branding: el Estado de la Marca España" de Francisco J. Hernández, recogida en Doxa (2013, vol. 16); "Marca país México: un logo con estética" de Reyna E. Hernández, en Gráfica (2013, vol. 1); o "Ciudades europeas en el cine" de Pablo Maraver, en Icono 14 (2013, vol. 11), entre otras.

${ }^{4}$ A modo anecdótico, comentar que algunas revistas también han publicado noticias de tesis doctorales relacionadas con nuestro objeto de estudio, como por ejemplo Doxa, que en su vol. 18 de 2014 informaba sobre la tesis "Marca ciudad, un activo estratégico en la gestión de la imagen urbana. Propuesta de un modelo estratégico de marca ciudad. Claves de una gestión consistente a través de un caso de estudio: ciudades españolas finalistas al título de la Capital Europea de la Cultura 2016", de Olga Kolotouchkina.

${ }^{5}$ Cabe precisar que uno de los artículos iba signado como "VV.AA." y no daba información del nombre ni del género de los autores, por lo que el porcentaje podría variar ligeramente en caso de disponer de dichos datos. Añadir también que "VV.AA." ha sido contabilizado como uno de los 149 autores diferenciados, si bien no se le ha contabilizado ni como hombre ni como mujer.

${ }^{6}$ Cabe precisar que en el artículo "El nacionalismo polaco a través de la película Kanal" del Fonseca Journal of Communication no aparecen ni el nombre ni la cantidad total de autores, pero sí que se incluyen dos universidades: la Universidad de Valladolid y la Universidad de Salamanca. Si bien desconocemos cuántos integrantes conformaban cada institución, hemos optado por contabilizar una única entrada por universidad.

\section{BIBLIOGRAFÍA}

ALAMEDA, D. y FERNÁNDEZ, E. La comunicación de las marcas territorio. Actas del IV Congreso Internacional Latina de Comunicación Social, 2012 [en línea]. Disponible en: $<$ http://www.revistalatinacs.org/12SLCS/2012_actas.html> [Consulta: 10 de marzo de 2016].

ANHOLT, S. Definitions of place branding - Working towards a resolution. Place Branding and Public Diplomacy, 2010, vol. 6, no 1, p. 1-10.

BALADRÓN-PAZOS, A.; CORREYERO-RUIZ, B. y MANCHADO PÉREZ, B. Tres décadas de investigación sobre publicidad en España. Análisis de las revistas científicas de comunicación (1980-2013). Communication and Society, 2014, vol. 27, no 4, p. 49-71.

BERELSON, B. Content Analysis in Communication Research. Glencoe: The Free Press, 1952.

BORGMAN, C.L. y FURNER, J. Scholarly communication and bibliometrics. Annual Review of Information Science and Technology, 2002, vol. 36, $\mathrm{n}^{\circ}$ 1, p. 2-72.

CANEL, M.J. y SANDERS, K. Para estudiar la comunicación de los gobiernos. Un análisis del estado de la cuestión. Comunicación y Sociedad, 2010, vol. 23, n⿳ 1, p. 7-48.

CASTILLO, A. y CARRETÓN, M.C. Investigación en Comunicación. Estudio bibliométrico de las revistas de Comunicación en España. Comunicación y Sociedad, 2010, vol. 13, nº 2, p. 289-327.

CASTILlO, A.; RUBIO, A. y ALMANSA, A. La investigación en Comunicación. Análisis bibliométrico de las revistas de mayor impacto del ISI. Revista Latina de Comunicación Social, 2012, vol. 67, p. 248-270. 
CASTILlO, A. y XIFRA, J. Investigación bibliométrica de las tesis doctorales españolas sobre relaciones públicas (1965-2005). Anàlisi, 2006, vol. 34, p. 141-161.

CUENCA-FONTBONA, J. La investigación estratégica preliminar. En MATILLA, K. (ed.), Cómo hacer un plan estratégico de Relaciones Públicas y Comunicación Corporativa, (Vol. III), Barcelona: UOC, 2016 (en imprenta).

DE BELLIS, N. Bibliometrics and Citation Analysis. From the Science Citation Index to Cybermetrics. Lanham, Maryland: The Scarecrow Press, 2009.

DE SAN EUGENIO, J. Teoría y métodos para marcas de territorio. Barcelona: UOC, 2012.

DE SAN EUGENIO, J. Del Estado-nación al Estado-marca. El rol de la diplomacia pública y la marca país en el nuevo escenario de las relaciones internacionales. Revista de Estudios Sociales, 2013, vol. 46, p. 145-157.

DE SAN EUGENIO, J.; FERNÁNDEZ-CAVIA, J.; NOGUÉ, J. y JIMÉNEZ-MORALES, M. Características y funciones para marcas de lugar a partir de un método Delphi. Revista Latina de Comunicación Social, 2013 , vol. 68, p. 656-675.

DE-FILIPPO, D. La producción científica española en Comunicación en WOS. Las revistas indexadas en SSCI (200712). Comunicar, 2013, vol. 21, no 41, p. 25-34.

DÍAZ CAMPOS, J. Análisis bibliométrico de las tesis doctorales sobre Ética de los Medios de Comunicación presentadas en España (1979-2013). Doxa Comunicación, 2014, vol. 20, p. 65-88.

DINNIE, K. Place Branding: Overview of an Emerging Literature. Place Branding and Public Diplomacy, 2004, vol. 1, p. 106-110.

FEELEY, T.H. A Bibliometric Analysis of Communication Journals from 2002 to 2005. Human Communication Research, 2008, vol. 34, p. 505-520.

FERNÁNDEZ-CAVIA, J. y HUERTAS, A. La gestión de las marcas de destino y de territorio desde la perspectiva de las relaciones públicas. Comunicació: Revista de Recerca y d'Anàlisi, 2014, vol. 31, nº 1, p. 9-26.

FERNÁNDEZ-QUIJADA, D. Dues dècades de comunicació científica: anàlisi bibliomètrica de les revistes de la Societat Catalana de Comunicació (1989-2009). Comunicació: Revista de Recerca i d'anàlisi, 2012, vol. 29, nº 1 , p. 126-151.

GOVERS, R. y GO, F. Place Branding. Glocal, Virtual and Physical Identities, Constructed, Imagined and Experienced. London, UK: Palgrave Macmillan, 2009.

GOVERS, R. From place marketing to place branding and back. Place Branding and Public Diplomacy, 2011, vol. 7, $n^{\circ} 4$, p. 227-231.

HANKINSON, G. Place branding research: A cross-disciplinary agenda and the views of practitioners. Place Branding and Public Diplomacy, 2010, vol. 6, n 4, p. 300-315.

HUERTAS, A. La comunicación de los territorios, los destinos y sus marcas: Guía práctica de aplicación desde las relaciones públicas. Barcelona: UOC, Colección Dircom, 2014.

KANEVA, N. Nation Branding: Toward an Agenda for Critical Research. International Journal of Communication, 2011, vol. 5, p. 117-141.

KAVARATZIS, M. y ASHWORTH, G.J. City branding: An effective assertion of identity or a transitory marketing trick? Tijdschrift voor Economische en Sociale Geografie, 2005, vol. 96, nº 5, p. 506-514.

KJÆRGAARD RASMUSSEN, R. y MERKELSEN, H. The new PR of states: How nation branding practices affect the security function of public diplomacy. Public Relations Review, 2012, vol. 38, nº 5, p. 810-818.

KRIPPENDORFF, K.H. Content Analysis: An introduction to its methodology. 3rd Edition. Thousand Oaks, CA: SAGE, 2013.

LA PORTE, M.T. La diplomacia pública americana. Lecciones para una comunicación internacional. Comunicación y Sociedad, 2007, vol. 20, no 2, p. 23-59.

LÓPEZ-MENESES, E.; VÁZQUEZ-CANO, E. y SARASOLA SÁNCHEZ-SERRANO, J.L. Estudio bibliométrico de Pixel-BIT: Revista de Medios y Educación (2000-2013). Pixel-BIT: Revista de Medios y Educación, 2015, $\mathrm{n}^{\circ}$ 46, $\mathrm{p}$. 65-85.

LÓPEZ NOGUERO, F. El análisis de contenido como método de investigación. Revista de Educación, 2002, vol. 4, p. 167-179.

LUCARELLI, A. y BERG, P. City branding: a state-of-the-art review of the research domain. Journal of Place Management and Development, 2011, vol. 4, n 1 , p. 9-27.

MANFREDI SÁNCHEZ, J.L. Hacia una teoría comunicativa de la diplomacia pública. Comunicación y Sociedad, 2011, vol. 24, nº 2, p. 199-225.

MARCA-FRANCÉS, J. La investigación estratégica de evaluación. En MATILLA, K. (ed.), Cómo hacer un plan estratégico de Relaciones Públicas y Comunicación Corporativa, (Vol. II). Barcelona: UOC, 2016 (en imprenta).

MARTÍNEZ-PECINO, R.; REIG, R. y MARTÍN-SÁNCHEZ, M. Una década del mensaje sobre la salud en las revistas de comunicación indexadas en IN-RECS (2000-2011). Estudios sobre el Mensaje Periodístico, 2013 , vol. 19, no 2, p. 1047-1059.

MELISSEN, J. The New Public Diplomacy. Soft Power in International Relations. London, UK: Palgrave Macmillan, 2005. 
MINISTERIO DE EDUCACIÓN, CULTURA Y DEPORTE DE ESPAÑA. Datos y cifras del sistema universitario español: Curso 2014-2015, 2015. Disponible en: <http://www.mecd.gob.es/dms/mecd/educacion-mecd/areaseducacion/universidades/estadisticas-informes/datos-cifras/Datos-y-Cifras-del-SUE-Curso-2014-2015.pdf> [Consulta: 8 de marzo de 2016)].

NARIN, F.; OLIVASTRO, D. y STEVENS, K.A. Bibliometrics/theory, practice and problems. Evaluation Review, 1994, vol. 18, nº 1, p. 65-76.

OLIVEIRA, A. Públicos y Stakeholders. En MATILlA, K. (ed.), Cómo hacer un plan estratégico de Relaciones Públicas y Comunicación Corporativa, (Vol. II). Barcelona: UOC, 2016 (en imprenta).

PASSOW, T.; FEHLMANN, R. y GRAHLOW, H. Country Reputation — From Measurement to Management: The Case of Liechtenstein. Corporate Reputation Review, 2005, vol. 7, no 4, p. 309-326.

PERES VENTI, N.A. Da bibliometria à webometria: uma exploração conceitual dos mecanismos utilizados para medir o registro da informação e a difusão do conhecimento. Brasilia, 2002, vol. 31, nº 2, p. 152-162.

REPISO, R.; TORRES, D. y DELGADO, E. Análisis bibliométrico y de redes sociales en tesis doctorales españolas sobre televisión (1976/2007). Comunicar, 2011a, vol. 37, p. 151-159.

REPISO, R.; TORRES, D. y DELGADO, E. Análisis de la investigación sobre radio en España: una aproximación a través del análisis bibliométrico y de redes sociales de las tesis doctorales defendidas en España entre 1976-2008. Estudios sobre el Mensaje Periodístico, 2011b, vol. 17, nº 2, p. 417-429.

REPISO, R. Aproximación bibliométrica del desarrollo e impacto de la investigación internacional en alfabetización audiovisual (1960-2011). ICONO 14, 2012, vol. 10, nº 3, p. 43-61.

REPISO, R.; TORRES, D. y DELGADO, E. La investigación científica sobre cine en España a partir de sus tesis doctorales: Análisis de redes sociales (1978-2007). ICONO 14, 2013, vol. 11, n 2, p. 385-404.

RODRÍGUEZ GÓMEZ, A. La comunicación como instrumento de la diplomacia pública. Estudios sobre el Mensaje Periodístico, 2013, vol. 19, no 1, p. 953-961.

SCHMOCH, U. y SCHUBERT, T. When and how to use bibliometrics as a screening tool for research performance. Science and Public Policy, 2009, vol. 36, $\mathrm{n}^{\circ}$ 10. p. 753-762.

SZONDI, G. Public diplomacy and nation branding: Conceptual similarities and differences. En DUTHOIT V. y HuIJGH, E. (eds.) Discussion Papers in Diplomacy. La Haya, Países Bajos: Clingendael Netherlands Institute of International Relations, 2008, p. 1-42.

THELWALL, M. Bibliometrics to webometrics. Journal of Information Science, 2008, vol. 34, no 4, p. 605-621.

VAN HAM, P. Place Branding: The State of the Art. The Annals of the American Academy of Political and Social Science, 2008, no 616, p. 126-149.

ZUGASTI AZAGRA, R. La investigación sobre Historia de la Comunicación en España: el caso de las revistas fuente de IN-RECS (2002-2012). Historia y Comunicación Social, 2013, vol. 18, p. 65-76.

\section{WEBGRAFÍA}

$<$ http://www.palgrave-journals.com/pb/index.html> 
ANEXOS

\begin{tabular}{|c|c|c|c|c|c|c|c|}
\hline $\begin{array}{l}\text { Título de } \\
\text { revista }\end{array}$ & $\begin{array}{l}\text { Editorial / } \\
\text { Asociación } \\
\text { Promotora }\end{array}$ & $\begin{array}{c}\text { Año de } \\
\text { Fundación } \\
\text { y Ciudad } \\
\text { de Edición }\end{array}$ & $\begin{array}{l}\text { Editor y/o } \\
\text { Director }\end{array}$ & ISSN & $\begin{array}{l}\text { Frecuenci } \\
\text { a publica- } \\
\text { ción }\end{array}$ & $\begin{array}{l}\text { Especialidad de la } \\
\text { revista }\end{array}$ & $\begin{array}{l}\text { Sitio web } \\
\text { oficial }\end{array}$ \\
\hline $\begin{array}{l}\text { 1. AdComunica: } \\
\text { Revista } \\
\text { científica de } \\
\text { estrategias, } \\
\text { tendencias e } \\
\text { innovación en } \\
\text { comunicación }\end{array}$ & $\begin{array}{l}\text { Universitat } \\
\text { Jaume I / } \\
\text { adComunica - } \\
\text { Asocación } \\
\text { para el } \\
\text { Desarrollo de } \\
\text { la Comuni- } \\
\text { cación }\end{array}$ & $\begin{array}{l}\text { 2011, } \\
\text { Castellón }\end{array}$ & $\begin{array}{c}\text { Javier } \\
\text { Marzal Felici } \\
\text { y Andreu } \\
\text { Casero } \\
\text { Ripollés }\end{array}$ & $\begin{array}{l}2174-0992 \\
\text { (impr.); } \\
2254-2728 \\
\text { (electr.) }\end{array}$ & Semestral & $\begin{array}{l}\text { Comunicación en } \\
\text { un sentido amplio, } \\
\text { principalmente } \\
\text { desde la } \\
\text { perspectiva de la } \\
\text { dirección } \\
\text { estratégica }\end{array}$ & $\begin{array}{l}\text { http://ww } \\
\text { w.adcomu } \\
\text { nicarevista } \\
\text {.com/ }\end{array}$ \\
\hline $\begin{array}{l}\text { 2. AdResearch } \\
\text { ESIC: Revista } \\
\text { Internacional de } \\
\text { Investigación en } \\
\text { Comunicación }\end{array}$ & $\begin{array}{l}\text { ESIC Business } \\
\text { \& Marketing } \\
\text { School }\end{array}$ & $\begin{array}{l}\text { 2010, } \\
\text { Madrid }\end{array}$ & $\begin{array}{c}\text { Teresa } \\
\text { Pintado } \\
\text { Blanco y } \\
\text { Julio Alard } \\
\text { Josemaría }\end{array}$ & & Semestral & $\begin{array}{l}\text { Aspectos generales } \\
\text { de la comunicación } \\
\text { comercial; } \\
\text { Publicidad; } \\
\text { Relaciones } \\
\text { Públicas; } \\
\text { Marketing directo; } \\
\text { Patrocinio/mecena } \\
\text { zgo; Promociones; } \\
\text { Comunicación en } \\
\text { el punto de venta; } \\
\text { Comunicación } \\
\text { especializada; } \\
\text { Nuevas tendencias } \\
\text { en comunicación }\end{array}$ & $\begin{array}{l}\text { http://adres } \\
\text { earch.esic. } \\
\text { edu/ }\end{array}$ \\
\hline $\begin{array}{l}\text { 3. Ámbitos. } \\
\text { Revista } \\
\text { Internacional de } \\
\text { Comunicación }\end{array}$ & $\begin{array}{l}\text { Universidad de } \\
\text { Sevilla / Dep. } \\
\text { de Periodismo }\end{array}$ & $\begin{array}{l}\text { 1998, } \\
\text { Sevilla }\end{array}$ & Ramón Reig & $\begin{array}{l}1139-1979 \\
\text { (impr.) } \\
1988-5733 \\
\text { (electr.) }\end{array}$ & Semestral & $\begin{array}{l}\text { Ciencias de la } \\
\text { comunicación, } \\
\text { Sociología }\end{array}$ & $\begin{array}{l}\text { http://ambi } \\
\text { toscomuni } \\
\text { cacion.co } \\
\mathrm{m} /\end{array}$ \\
\hline $\begin{array}{l}\text { 4. Anàlisi: } \\
\text { Quaderns de } \\
\text { Comunicació i } \\
\text { Cultura }\end{array}$ & $\begin{array}{l}\text { Ed. Oberta } \\
\text { Publishing / } \\
\text { Universitat } \\
\text { Autònoma de } \\
\text { Barcelona y } \\
\text { Universitat } \\
\text { Oberta de } \\
\text { Catalunya }\end{array}$ & $\begin{array}{c}\text { 1980, } \\
\text { Barcelona }\end{array}$ & $\begin{array}{l}\text { Daniel } \\
\text { Aranda y } \\
\text { Charo } \\
\text { Lacalle }\end{array}$ & $2340-5236$ & Semestral & $\begin{array}{l}\text { Estudios sobre la } \\
\text { comunicación en el } \\
\text { contexto digital; la } \\
\text { sociedad digital; } \\
\text { comunicación y } \\
\text { género; consumo } \\
\text { de canales y } \\
\text { medios } \\
\text { emergentes; } \\
\text { comunicación y } \\
\text { educación; hábitos } \\
\text { digitales en el } \\
\text { tiempo libre; } \\
\text { comunicación } \\
\text { política; nuevas } \\
\text { formas de } \\
\text { producción y } \\
\text { financiación; } \\
\text { transmedia } \\
\text { storytelling; } \\
\text { periodismo de } \\
\text { datos; retos de la } \\
\text { publicidad }\end{array}$ & $\begin{array}{l}\text { http://journ } \\
\text { als.uoc.edu } \\
\text { /index.php/ } \\
\text { analisi/abo } \\
\text { ut }\end{array}$ \\
\hline $\begin{array}{l}\text { 5. Anuarios } \\
\text { Thinkepi }\end{array}$ & Editorial UOC & $\begin{array}{c}2007, \\
\text { Barcelona }\end{array}$ & $\begin{array}{l}\text { Tomàs } \\
\text { Baiget }\end{array}$ & 1886-6344 & Anual & $\begin{array}{l}\text { Biblioteconomía, } \\
\text { documentación, } \\
\text { ciencias e } \\
\text { industrias de la }\end{array}$ & $\begin{array}{l}\text { http://ww } \\
\text { w.thinkepi. } \\
\text { net/anuario } \\
\text {-thinkepi }\end{array}$ \\
\hline
\end{tabular}




\begin{tabular}{|c|c|c|c|c|c|c|c|}
\hline & & & & & & $\begin{array}{l}\text { información y } \\
\text { comunicación }\end{array}$ & \\
\hline 6. Area Abierta & $\begin{array}{l}\text { Servicio de } \\
\text { Publicaciones } \\
\text { Universidad } \\
\text { Complutense } \\
\text { de Madrid / } \\
\text { Dep. de } \\
\text { Publicidad I }\end{array}$ & $\begin{array}{l}\text { 2001, } \\
\text { Madrid }\end{array}$ & $\begin{array}{l}\text { Norberto } \\
\text { Mínguez } \\
\text { Arranz }\end{array}$ & $1578-8393$ & $\begin{array}{l}\text { Cuatri- } \\
\text { mestral }\end{array}$ & $\begin{array}{c}\text { Comunicación } \\
\text { audiovisual y } \\
\text { publicidad }\end{array}$ & $\begin{array}{l}\text { https://revi } \\
\text { stas.ucm.e } \\
\text { s/index.ph } \\
\text { p/ARAB }\end{array}$ \\
\hline $\begin{array}{c}7 . \\
\text { Caleidoscopio: } \\
\text { Revista del } \\
\text { audiovisual }\end{array}$ & $\begin{array}{l}\text { Universidad } \\
\text { CEU Cardenal } \\
\text { Herrera / Dep. } \\
\text { de Comuni- } \\
\text { cación } \\
\text { Audiovisual }\end{array}$ & $\begin{array}{l}\text { Entre } 2000 \\
\text { y 2001, } \\
\text { Alfara del } \\
\text { Patriarca } \\
\text { (Valencia) }\end{array}$ & $\begin{array}{l}\text { Santiago } \\
\text { Maestro } \\
\text { Cano }\end{array}$ & $1695-7172$ & Irregular & $\begin{array}{l}\text { Comunicación } \\
\text { social, cine y } \\
\text { comunicación } \\
\text { audiovisual }\end{array}$ & No tiene \\
\hline $\begin{array}{c}\text { 8. Catalan } \\
\text { Social Sciences } \\
\text { Review }\end{array}$ & $\begin{array}{l}\text { Institut } \\
\text { d'Estudis } \\
\text { Catalans / } \\
\text { Sección de } \\
\text { Filosofía y } \\
\text { Ciencias } \\
\text { Sociales }\end{array}$ & $\begin{array}{c}2012, \\
\text { Barcelona }\end{array}$ & $\begin{array}{l}\text { Josep Maria } \\
\text { Casasús i } \\
\text { Guri }\end{array}$ & 2014-6035 & Anual & $\begin{array}{c}\text { Filosofía, } \\
\text { pedagogía, } \\
\text { sociología, } \\
\text { demografia, leyes, } \\
\text { economía, } \\
\text { antropología, } \\
\text { comunicación y } \\
\text { ciencias políticas }\end{array}$ & $\begin{array}{c}\text { http://revis } \\
\text { tes.iec.cat/i } \\
\text { ndex.php/ } \\
\text { CSSr/inde } \\
\text { x }\end{array}$ \\
\hline $\begin{array}{l}\text { 9. CIC. } \\
\text { Cuadernos de } \\
\text { Información y } \\
\text { Comunicación }\end{array}$ & $\begin{array}{l}\text { Servicio de } \\
\text { Publicaciones } \\
\text { Universidad } \\
\text { Complutense } \\
\text { de Madrid / } \\
\text { Dep. de } \\
\text { Periodismo III }\end{array}$ & $\begin{array}{l}\text { 1995, } \\
\text { Madrid }\end{array}$ & $\begin{array}{l}\text { Eva Aladro } \\
\text { Vico }\end{array}$ & $\begin{array}{l}1135-7991 \\
\text { (impr.), } \\
\text { 1988-4001 } \\
\text { (electr.) }\end{array}$ & Anual & $\begin{array}{l}\text { Comunicación e } \\
\text { información }\end{array}$ & $\begin{array}{l}\text { https://revi } \\
\text { stas.ucm.e } \\
\text { s/index.ph } \\
\text { p/CIYC }\end{array}$ \\
\hline $\begin{array}{l}\text { 10. Commons: } \\
\text { Revista de } \\
\text { Comunicación y } \\
\text { Ciudadanía } \\
\text { Digital }\end{array}$ & $\begin{array}{l}\text { Universidad de } \\
\text { Cádiz }\end{array}$ & $\begin{array}{l}\text { 2012, Jerez } \\
\text { de la } \\
\text { Frontera } \\
\text { (Cádiz) }\end{array}$ & $\begin{array}{c}\text { Victor } \\
\text { Manuel Mari } \\
\text { Saez }\end{array}$ & $2255-3401$ & Bianual & $\begin{array}{c}\text { La comunicación, } \\
\text { concebida como lo } \\
\text { común y lo } \\
\text { público, } \\
\text { incluyendo } \\
\text { Publicidad Social y } \\
\text { Tercer Sector } \\
\text { Audiovisual; } \\
\text { Comunicación para } \\
\text { el Desarrollo y el } \\
\text { Cambio Social }\end{array}$ & $\begin{array}{l}\text { http://reure } \\
\text { dc.uca.es/i } \\
\text { ndex.php/c } \\
\text { ayp }\end{array}$ \\
\hline $\begin{array}{c}11 . \\
\text { Communication } \\
\text { Papers: Medios } \\
\text { de alfabetización } \\
\text { y estudios de } \\
\text { género }\end{array}$ & $\begin{array}{c}\text { Universidad de } \\
\text { Girona / Grupo } \\
\text { de } \\
\text { investigación } \\
\text { ARPA }\end{array}$ & $\begin{array}{l}\text { 2012, } \\
\text { Girona }\end{array}$ & $\begin{array}{l}\text { Carmen } \\
\text { Echazarreta } \\
\text { Soler }\end{array}$ & $2014-6752$ & Semestral & $\begin{array}{l}\text { Periodismo, } \\
\text { Comunicación } \\
\text { Audiovisual y } \\
\text { Publicidad }\end{array}$ & $\begin{array}{l}\text { http://ww } \\
\text { w.commun } \\
\text { icationpap } \\
\text { ers.com/ }\end{array}$ \\
\hline $\begin{array}{c}12 . \\
\text { Comunicación y } \\
\text { Sociedad }{ }^{1}= \\
\text { Communication } \\
\& \text { Society }\end{array}$ & $\begin{array}{c}\text { Servicio de } \\
\text { Publicaciones } \\
\text { de la } \\
\text { Universidad de } \\
\text { Navarra / } \\
\text { Facultad de } \\
\text { Comunicación }\end{array}$ & $\begin{array}{l}\text { 1988-2014, } \\
\text { Pamplona }\end{array}$ & $\begin{array}{l}\text { Carlos } \\
\text { Barrera }\end{array}$ & $\begin{array}{l}0214-0039 \\
\text { (impr.); } \\
2174-0895 \\
\text { (electr.) }\end{array}$ & Trimestral & $\begin{array}{c}\text { Periodismo, } \\
\text { Publicidad, } \\
\text { Relaciones } \\
\text { Públicas, } \\
\text { Comunicación } \\
\text { Audiovisual, } \\
\text { Comunicación } \\
\text { Política, Ética, } \\
\text { Historia mediática, } \\
\text { Políticas de } \\
\text { comunicación, } \\
\text { economía política } \\
\text { y nuevos medios }\end{array}$ & $\begin{array}{l}\text { http://ww } \\
\text { w.unav.es/ } \\
\text { fcom/com } \\
\text { munication } \\
\text { - } \\
\text { society/en/ } \\
\text { index.php }\end{array}$ \\
\hline $\begin{array}{c}13 . \\
\text { Comunicació }^{2} \text {. } \\
\text { Revista de } \\
\text { investigación y } \\
\text { análisis }\end{array}$ & $\begin{array}{c}\text { Societat } \\
\text { Catalana de } \\
\text { Comunicació }\end{array}$ & $\begin{array}{l}\text { 1991-2010, } \\
\text { Barcelona }\end{array}$ & $\begin{array}{l}\text { Sergi } \\
\text { Cortiñas } \\
\text { Rovira, } \\
\text { Reinald } \\
\text { Besalú }\end{array}$ & $\begin{array}{l}\text { 2014-0304 } \\
\text { (impr.), } \\
\text { 2014-0444 } \\
\text { (electr.) }\end{array}$ & Semestral & $\begin{array}{l}\text { Comunicación } \\
\text { como ciencia } \\
\text { social }\end{array}$ & $\begin{array}{l}\text { http://revis } \\
\text { tes.iec.cat/i } \\
\text { ndex.php/ } \\
\text { TC/index }\end{array}$ \\
\hline
\end{tabular}




\begin{tabular}{|c|c|c|c|c|c|c|c|}
\hline $\begin{array}{c}14 . \\
\text { Comunicación. } \\
\text { Revista } \\
\text { Internacional de } \\
\text { Comunicación } \\
\text { Audiovisual, } \\
\text { Publicidad y } \\
\text { Estudios } \\
\text { Culturales }\end{array}$ & $\begin{array}{c}\text { Universidad de } \\
\text { Sevilla / Dep. } \\
\text { de } \\
\text { Comunicación } \\
\text { Audiovisual, } \\
\text { Publicidad y } \\
\text { Literatura }\end{array}$ & $\begin{array}{l}2002, \\
\text { Sevilla }\end{array}$ & $\begin{array}{l}\text { Juan Carlos } \\
\text { Rodríguez } \\
\text { Centeno }\end{array}$ & $\begin{array}{l}1989- \\
600 \mathrm{X}\end{array}$ & Anual & $\begin{array}{l}\text { Comunicación } \\
\text { Audiovisual, } \\
\text { Publicidad, } \\
\text { Relaciones } \\
\text { Públicas, } \\
\text { Propaganda, } \\
\text { Estudios } \\
\text { Culturales, Teoría } \\
\text { e Investigación en } \\
\text { Comunicación }\end{array}$ & $\begin{array}{l}\text { http://ww } \\
\text { w.revistac } \\
\text { omunicaci } \\
\text { on.org/ind } \\
\text { ex.htm }\end{array}$ \\
\hline $\begin{array}{c}15 . \\
\text { Comunicación y } \\
\text { Estudios } \\
\text { Universitarios }\end{array}$ & $\begin{array}{c}\text { CEU San } \\
\text { Pablo / Centro } \\
\text { Universitario } \\
\text { de Ciencias de } \\
\text { la Información }\end{array}$ & $\begin{array}{c}\text { 1990-2005, } \\
\text { Valencia }\end{array}$ & $\begin{array}{l}\text { Fundación } \\
\text { Universitaria } \\
\text { San Pablo } \\
\text { CEU }\end{array}$ & $\begin{array}{l}1132- \\
127 \mathrm{X}\end{array}$ & Anual & $\begin{array}{l}\text { Comunicación } \\
\text { Audiovisual y } \\
\text { Publicidad }\end{array}$ & No tiene \\
\hline $\begin{array}{c}16 . \\
\text { Comunicación y } \\
\text { Hombre. Revista } \\
\text { interdisciplinar } \\
\text { de Ciencias de la } \\
\text { Comunicación y } \\
\text { Humanidades }\end{array}$ & $\begin{array}{l}\text { Universidad } \\
\text { Francisco de } \\
\text { Vitoria / } \\
\text { Facultad de } \\
\text { Ciencias de la } \\
\text { Comunicación }\end{array}$ & $\begin{array}{l}2005, \\
\text { Pozuelo de } \\
\text { Alarcón } \\
\text { (Madrid) }\end{array}$ & $\begin{array}{l}\text { Elena } \\
\text { Pedreira } \\
\text { Souto }\end{array}$ & $\begin{array}{l}1885- \\
365 X\end{array}$ & Anual & $\begin{array}{l}\text { Disciplinas que } \\
\text { tienen relación } \\
\text { directa con la } \\
\text { comunicación } \\
\text { desde el punto de } \\
\text { vista humanístico }\end{array}$ & $\begin{array}{l}\text { http://ww } \\
\text { w.comunic } \\
\text { acionyhom } \\
\text { bre.com/ }\end{array}$ \\
\hline $\begin{array}{l}\text { 17. Comunicar. } \\
\text { Revista } \\
\text { Científica de } \\
\text { Comunicación y } \\
\text { Educación }\end{array}$ & $\begin{array}{c}\text { Grupo } \\
\text { Comunicar }\end{array}$ & $\begin{array}{c}\text { 1993, } \\
\text { Huelva }\end{array}$ & $\begin{array}{l}\text { Ignacio } \\
\text { Aguaded }\end{array}$ & $\begin{array}{l}1134-3478 \\
\text { (impr.), } \\
1988-3293 \\
\text { (electr.) }\end{array}$ & Trimestral & $\begin{array}{l}\text { Educomunicación, } \\
\text { comunicación y } \\
\text { educación, TIC, } \\
\text { audiencias, nuevos } \\
\text { lenguajes }\end{array}$ & $\begin{array}{c}\text { http://ww } \\
\text { w.revistac } \\
\text { omunicar.c } \\
\text { om/ }\end{array}$ \\
\hline $\begin{array}{l}\text { 18. Conexiones. } \\
\text { Revista } \\
\text { Iberoamericana } \\
\text { de } \\
\text { Comunicación }\end{array}$ & $\begin{array}{c}\text { Observatorio } \\
\text { Iberoamerican } \\
\text { o de la } \\
\text { Comunicación } \\
\text { de la Facultad } \\
\text { de Ciencias de } \\
\text { la } \\
\text { Comunicación } \\
\text { - Universidad } \\
\text { Autónoma de } \\
\text { Barcelona }\end{array}$ & $\begin{array}{c}2009 \\
\text { Salamanca }\end{array}$ & $\begin{array}{c}\text { Marcial } \\
\text { Murciano }\end{array}$ & $1697-3720$ & Irregular & $\begin{array}{l}\text { Comunicación, } \\
\text { Periodismo, } \\
\text { Estudios sobre los } \\
\text { medios }\end{array}$ & $\begin{array}{l}\text { http://com } \\
\text { unicacions } \\
\text { ocial.es/re } \\
\text { vista- } \\
\text { conexiones }\end{array}$ \\
\hline $\begin{array}{l}\text { 19. Derecom. } \\
\text { Revista } \\
\text { Internacional } \\
\text { Online de } \\
\text { Derecho de la } \\
\text { Comunicación }\end{array}$ & $\begin{array}{c}\text { Servicios de } \\
\text { Publicaciones } \\
\text { de la } \\
\text { Universidad } \\
\text { Complutense } \\
\text { de Madrid / } \\
\text { Facultad de } \\
\text { Ciencias de la } \\
\text { Información }\end{array}$ & $\begin{array}{l}\text { 2010, } \\
\text { Madrid }\end{array}$ & $\begin{array}{l}\text { María Pilar } \\
\text { Cousido } \\
\text { González }\end{array}$ & $1988-2629$ & Trimestral & $\begin{array}{l}\text { Derecho de la } \\
\text { Información }\end{array}$ & $\begin{array}{l}\text { http://ww } \\
\text { w.derecom } \\
\text {.com (no } \\
\text { ofrece } \\
\text { informa- } \\
\text { ción sobre } \\
\text { los } \\
\text { artículos } \\
\text { publica- } \\
\text { dos) }\end{array}$ \\
\hline $\begin{array}{l}\text { 20. Dígitos. } \\
\text { Revista de } \\
\text { Comunicación } \\
\text { Digital }\end{array}$ & $\begin{array}{l}\text { Universidad de } \\
\text { Valencia / } \\
\text { Dep. de Teoría } \\
\text { de los } \\
\text { Lenguajes y } \\
\text { Ciencias de la } \\
\text { Comunicación }\end{array}$ & $\begin{array}{c}2014, \\
\text { Valencia }\end{array}$ & $\begin{array}{c}\text { Guillermo } \\
\text { López García }\end{array}$ & 2444-0132 & Anual & $\begin{array}{c}\text { Comunicación } \\
\text { digital }\end{array}$ & $\begin{array}{l}\text { http://revis } \\
\text { tadigitos.c } \\
\text { om/index.p } \\
\text { hp/digitos }\end{array}$ \\
\hline $\begin{array}{c}\text { 21. Doxa. } \\
\text { Revista } \\
\text { Interdisciplinar } \\
\text { de Estudios de } \\
\text { Comunicación y } \\
\text { Ciencias } \\
\text { Sociales } \\
\end{array}$ & $\begin{array}{c}\text { CEU } \\
\text { Ediciones / } \\
\text { Universidad } \\
\text { CEU San } \\
\text { Pablo }\end{array}$ & $\begin{array}{l}\text { 2003, } \\
\text { Madrid }\end{array}$ & $\begin{array}{l}\text { Ignacio } \\
\text { Blanco } \\
\text { Alfonso }\end{array}$ & $\begin{array}{l}1696- \\
019 X\end{array}$ & Semestral & $\begin{array}{l}\text { Periodismo, } \\
\text { Opinión Pública, } \\
\text { Derecho de la } \\
\text { Información, } \\
\text { Publicidad y } \\
\text { Comunicación } \\
\text { Audiovisual }\end{array}$ & $\begin{array}{l}\text { http://ww } \\
\text { w.doxaco } \\
\text { municacio } \\
\text { n.es/ }\end{array}$ \\
\hline
\end{tabular}




\begin{tabular}{|c|c|c|c|c|c|c|c|}
\hline $\begin{array}{c}\text { 22. El } \\
\text { Profesional de la } \\
\text { Información }{ }^{3} \text {. } \\
\text { Revista } \\
\text { internacional de } \\
\text { Información y } \\
\text { Comunicación }\end{array}$ & $\begin{array}{l}\text { El Profesional } \\
\text { de la } \\
\text { Información }\end{array}$ & $\begin{array}{c}\text { 1992, } \\
\text { Barcelona }\end{array}$ & $\begin{array}{l}\text { Tomàs } \\
\text { Baiget }\end{array}$ & $\begin{array}{l}\text { 1386-6710 } \\
\text { (impr.), } \\
1699-2407 \\
\text { (electr.) }\end{array}$ & Bimestral & $\begin{array}{c}\text { Información, } \\
\text { bibliotecas y } \\
\text { nuevas tecnologías } \\
\text { de la información }\end{array}$ & $\begin{array}{l}\text { http://ww } \\
\text { w.elprofesi } \\
\text { onaldelainf } \\
\text { ormacion.c } \\
\text { om/index.h } \\
\text { tml }\end{array}$ \\
\hline $\begin{array}{l}\text { 23. Estudios } \\
\text { sobre el mensaje } \\
\text { periodístico }\end{array}$ & $\begin{array}{c}\text { Servicio de } \\
\text { Publicaciones } \\
\text { de la } \\
\text { Universidad } \\
\text { Complutense / } \\
\text { Dep. de } \\
\text { Periodismo I }\end{array}$ & $\begin{array}{l}\text { 1994, } \\
\text { Madrid }\end{array}$ & $\begin{array}{l}\text { María Jesús } \\
\text { Casals Carro }\end{array}$ & $\begin{array}{l}\text { 1134-1629 } \\
\text { (impr.), } \\
\text { 1988-2696 } \\
\text { (electr.) }\end{array}$ & $\begin{array}{l}\text { Semestral } \\
\text { (desde } \\
2011)\end{array}$ & Periodismo & $\begin{array}{l}\text { https://revi } \\
\text { stas.ucm.e } \\
\text { s/index.ph } \\
\text { p/ESMP }\end{array}$ \\
\hline 24.Etic@net & $\begin{array}{c}\text { Universidad de } \\
\text { Granada / } \\
\text { Grupo de } \\
\text { Investigación } \\
\text { TEIS } \\
\text { (Tecnología } \\
\text { Educativa e } \\
\text { Investigación } \\
\text { Social) }\end{array}$ & $\begin{array}{l}\text { 2002, } \\
\text { Granada }\end{array}$ & $\begin{array}{c}\text { José Antonio } \\
\text { Ortega } \\
\text { Carrillo }\end{array}$ & $\begin{array}{l}1695- \\
324 X\end{array}$ & Semestral & $\begin{array}{c}\text { Medios, Educación } \\
\text { y Comunicación en } \\
\text { la Sociedad del } \\
\text { Conocimiento, } \\
\text { Enseñanza a } \\
\text { distancia, Brecha } \\
\text { digital }\end{array}$ & $\begin{array}{l}\text { http://etica } \\
\text { net.org/rev } \\
\text { ista/ }\end{array}$ \\
\hline $\begin{array}{l}\text { 25. Eu-topías. } \\
\text { Revista de } \\
\text { interculturalidad, } \\
\text { comunicación y } \\
\text { estudios } \\
\text { europeos }\end{array}$ & $\begin{array}{c}\text { Universidad de } \\
\text { Valencia (Dep. } \\
\text { de Teoría de } \\
\text { los Lenguajes } \\
\text { y Ciencias de } \\
\text { la } \\
\text { Comunicación) } \\
\text { y The Global } \\
\text { Studies } \\
\text { Institute de } \\
\text { l'Université de } \\
\text { Genève }\end{array}$ & $\begin{array}{c}\text { 2011, } \\
\text { Valencia }\end{array}$ & $\begin{array}{l}\text { Jenaro } \\
\text { Talens }\end{array}$ & $\begin{array}{l}2174-8454 \\
\text { (impr.), } \\
2012-1206 \\
\text { (electr.) }\end{array}$ & Semestral & $\begin{array}{l}\text { Interculturalidad, } \\
\text { Mediación } \\
\text { interesada, } \\
\text { Estudios europeos }\end{array}$ & $\begin{array}{l}\text { http://eu- } \\
\text { topias.org/ }\end{array}$ \\
\hline $\begin{array}{l}\text { 26. Fonseca. } \\
\text { Journal of } \\
\text { Communication }\end{array}$ & $\begin{array}{c}\text { Ediciones } \\
\text { Universidad de } \\
\text { Salamanca / } \\
\text { Dep. de } \\
\text { Sociología y } \\
\text { Comunicación }\end{array}$ & $\begin{array}{c}2010, \\
\text { Salamanca }\end{array}$ & $\begin{array}{l}\text { Begoña } \\
\text { Gutiérrez } \\
\text { Miguel }\end{array}$ & $2172-9077$ & Semestral & $\begin{array}{l}\text { Cine, radio, } \mathrm{TV} \text {, } \\
\text { medios digitales }\end{array}$ & $\begin{array}{c}\text { http://revis } \\
\text { tas.usal.es/ } \\
\text { index.php/ } \\
\text { 2172- } \\
\text { 9077/index }\end{array}$ \\
\hline $\begin{array}{l}\text { 27. Formats. } \\
\text { Revista de } \\
\text { Comunicació } \\
\text { Audiovisual }\end{array}$ & $\begin{array}{l}\text { Universitat } \\
\text { Pompeu Fabra } \\
\text { / Grupos de } \\
\text { investigación } \\
\text { UNICA y } \\
\text { CINEMA }\end{array}$ & $\begin{array}{l}\text { 1997-2009, } \\
\text { Barce-lona }\end{array}$ & $\begin{array}{l}\text { Josep Gifreu } \\
\text { y Xavier } \\
\text { Pérez }\end{array}$ & $2385-3697$ & Irregular & $\begin{array}{l}\text { Cine, Televisión, } \\
\text { Teoría de la } \\
\text { Imagen, } \\
\text { Comunicación } \\
\text { Interactiva }\end{array}$ & $\begin{array}{l}\text { https://ww } \\
\text { w.upf.edu/ } \\
\text { materials/d } \\
\text { epeca/form } \\
\text { ats/si_flash } \\
\text { 2.htm }\end{array}$ \\
\hline 28. Grafica & $\begin{array}{c}\text { Universidad } \\
\text { Autónoma de } \\
\text { Barcelona / } \\
\text { Dep. de } \\
\text { Publicidad, RP } \\
\text { y CAV }\end{array}$ & $\begin{array}{c}2013, \\
\text { Bellaterra } \\
\text { (Barcelona) }\end{array}$ & $\begin{array}{c}\text { Ana Entenza } \\
\text { Rodríguez, } \\
\text { Daniel Tena } \\
\text { Parera }\end{array}$ & 2014-9298 & Semestral & $\begin{array}{l}\text { Diseño gráfico y } \\
\text { Comunicación }\end{array}$ & $\begin{array}{l}\text { http://revis } \\
\text { tes.uab.cat/ } \\
\text { grafica }\end{array}$ \\
\hline $\begin{array}{l}\text { 29. Historia y } \\
\text { comunicación } \\
\text { social }\end{array}$ & $\begin{array}{c}\text { Servicio de } \\
\text { Publicaciones } \\
\text { de la } \\
\text { Universidad } \\
\text { Complutense / } \\
\text { Dep. de } \\
\text { Historia de la } \\
\text { Comunicación } \\
\text { Social }\end{array}$ & $\begin{array}{c}\text { 1996, } \\
\text { Madrid }\end{array}$ & $\begin{array}{c}\text { Isabel } \\
\text { Tajahuerce } \\
\text { Ángel, Juan } \\
\text { José } \\
\text { Fernández } \\
\text { Sanz }\end{array}$ & $\begin{array}{l}\text { 1137-0734 } \\
\text { (impr.), } \\
\text { 1988-3056 } \\
\text { (electr.) }\end{array}$ & Anual & $\begin{array}{c}\text { Historia } \\
\text { Contemporánea, } \\
\text { Historia del } \\
\text { Pensamiento, } \\
\text { Historia de los } \\
\text { Medios de } \\
\text { Comunicación }\end{array}$ & $\begin{array}{l}\text { https://revi } \\
\text { stas.ucm.e } \\
\text { s/index.ph } \\
\text { p/HICS }\end{array}$ \\
\hline
\end{tabular}




\begin{tabular}{|c|c|c|c|c|c|c|c|}
\hline $\begin{array}{l}\text { 30. I-C. Revista } \\
\text { Científica de } \\
\text { Información y } \\
\text { Comunicación }\end{array}$ & $\begin{array}{c}\text { Secretariado } \\
\text { de } \\
\text { Publicaciones } \\
\text { de la } \\
\text { Universidad de } \\
\text { Sevilla / Dep. } \\
\text { de Periodismo } \\
\text { I }\end{array}$ & $\begin{array}{l}\text { 2003, } \\
\text { Sevilla }\end{array}$ & $\begin{array}{c}\text { María } \\
\text { Lamuedra } \\
\text { Graván }\end{array}$ & $\begin{array}{l}\text { 1696-2508 } \\
\text { (impr.); } \\
2173-1071 \\
\text { (electr.) }\end{array}$ & Anual & $\begin{array}{l}\text { Epistemología de } \\
\text { la Comunicación; } \\
\text { Teorías de la } \\
\text { Comunicación } \\
\text { orientadas al } \\
\text { cambio social; } \\
\text { Historia social de } \\
\text { la Comunicación; } \\
\text { Cultura popular } \\
\text { mediática; Cultura } \\
\text { de los medios } \\
\text { digitales }\end{array}$ & $\begin{array}{c}\text { http://ic- } \\
\text { journal.org } \\
/ /\end{array}$ \\
\hline $\begin{array}{l}\text { 31. ICONO } 14 . \\
\text { Revista } \\
\text { científica de } \\
\text { Comunicación y } \\
\text { Tecnologías } \\
\text { emergentes }\end{array}$ & $\begin{array}{c}\text { Asociación } \\
\text { Científica } \\
\text { ICONO14 / } \\
\text { Grupo } \\
\text { Ciberimaginario } \\
\text { Facultad de } \\
\text { Ciencias de la } \\
\text { Comunicación } \\
\text { Universidad } \\
\text { Rey Juan } \\
\text { Carlos }\end{array}$ & $\begin{array}{l}\text { 2003, } \\
\text { Madrid }\end{array}$ & $\begin{array}{c}\text { Francisco } \\
\text { García y } \\
\text { Manuel } \\
\text { Gertrudix }\end{array}$ & $\begin{array}{c}1697-8293 \\
\text { (electr.) }\end{array}$ & Semestral & $\begin{array}{l}\text { Tecnologías de la } \\
\text { Información y la } \\
\text { Comunicación y } \\
\text { cómo afectan al } \\
\text { fenómeno } \\
\text { comunicativo }\end{array}$ & $\begin{array}{l}\text { http://ww } \\
\text { w.icono14. } \\
\text { net/ojs/ind } \\
\text { ex.php/ico } \\
\text { no14 }\end{array}$ \\
\hline $\begin{array}{l}\text { 32. IDP. Revista } \\
\text { de Internet, } \\
\text { Derecho y } \\
\text { Política }\end{array}$ & $\begin{array}{c}\text { Oberta } \\
\text { Publishing / } \\
\text { Estudios de } \\
\text { Derecho y } \\
\text { Ciencia } \\
\text { Política - } \\
\text { Universitat } \\
\text { Oberta de } \\
\text { Catalunya }\end{array}$ & $\begin{array}{c}2005, \\
\text { Barcelona }\end{array}$ & $\begin{array}{l}\text { Ana María } \\
\text { Delgado }\end{array}$ & $1699-8154$ & Semestral & $\begin{array}{l}\text { Tecnologías de la } \\
\text { Información y la } \\
\text { Comunicación } \\
\text { aplicadas al } \\
\text { Derecho, la } \\
\text { Política y la } \\
\text { Administración } \\
\text { Pública }\end{array}$ & $\begin{array}{l}\text { http://journ } \\
\text { als.uoc.edu } \\
\text { /index.php/ } \\
\text { idp/ }\end{array}$ \\
\hline $\begin{array}{l}\text { 33. Index. } \\
\text { Comunicación }\end{array}$ & $\begin{array}{c}\text { Universidad } \\
\text { Rey Juan } \\
\text { Carlos / Dep. } \\
\text { de Ciencias de } \\
\text { la } \\
\text { Comunicación } \\
\text { I }\end{array}$ & $\begin{array}{l}2011, \\
\text { Fuenla- } \\
\text { brada }\end{array}$ & $\begin{array}{c}\text { Pedro Pérez } \\
\text { Cuadrado }\end{array}$ & 2174-1859 & Anual & $\begin{array}{l}\text { Ciencias de la } \\
\text { Comunicación }\end{array}$ & $\begin{array}{c}\text { http://journ } \\
\text { als.sfu.ca/i } \\
\text { ndexcomu } \\
\text { nicacion/in } \\
\text { dex.php/in } \\
\text { dexcomuni } \\
\text { cacion/abo } \\
\text { ut }\end{array}$ \\
\hline 34. Infoamérica & $\begin{array}{l}\text { Universidad de } \\
\text { Málaga, } \\
\text { Cátedra } \\
\text { UNESCO de } \\
\text { Comunicación }\end{array}$ & $\begin{array}{l}\text { 2009, } \\
\text { Málaga }\end{array}$ & $\begin{array}{l}\text { Bernardo } \\
\text { Díaz Nosty }\end{array}$ & $1889-6251$ & $\begin{array}{l}\text { Cuatri- } \\
\text { mestral }\end{array}$ & $\begin{array}{l}\text { Ciencias de la } \\
\text { Comunicación }\end{array}$ & $\begin{array}{l}\text { http://ww } \\
\text { w.infoame } \\
\text { rica.org/ }\end{array}$ \\
\hline $\begin{array}{c}\text { 35. La } \\
\text { Comunicación } \\
\text { empresarial y la } \\
\text { gestión de los } \\
\text { intangibles en } \\
\text { España y } \\
\text { Latinoamérica }\end{array}$ & $\begin{array}{c}\text { Gedisa } \\
\text { Editorial / } \\
\text { Villafañe y } \\
\text { Asociados }\end{array}$ & $\begin{array}{l}\text { 1999, } \\
\text { Madrid }\end{array}$ & $\begin{array}{c}\text { Justo } \\
\text { Villafañe }\end{array}$ & $2255-1980$ & Anual & $\begin{array}{l}\text { Ciencias de la } \\
\text { comunicación, } \\
\text { Economía de la } \\
\text { empresa }\end{array}$ & $\begin{array}{c}\text { http://ww } \\
\text { w.villafane } \\
\text {.com/publi } \\
\text { caciones }\end{array}$ \\
\hline 36. Lengcom & Lengcom & $\begin{array}{l}\text { 2014, } \\
\text { Huelva }\end{array}$ & $\begin{array}{c}\text { Ígor } \\
\text { Rodríguez } \\
\text { Iglesias }\end{array}$ & $2386-7477$ & $\begin{array}{c}\text { Continuad } \\
\text { a }\end{array}$ & $\begin{array}{l}\text { Ciencias sociales y } \\
\text { humanidades, } \\
\text { Lingüística, } \\
\text { Filología, Ciencias } \\
\text { de la comunicación }\end{array}$ & $\begin{array}{l}\text { http://ww } \\
\text { w.lengcom } \\
\text {.es/ }\end{array}$ \\
\hline $\begin{array}{l}\text { 37. Logo: } \\
\text { Revista de } \\
\text { Retórica y } \\
\text { Teoría de la } \\
\text { Comunicación }\end{array}$ & $\begin{array}{l}\text { Universidad de } \\
\text { Salamanca, } \\
\text { Facultad de } \\
\text { Filología / } \\
\text { Asociación } \\
\text { Española de } \\
\text { Estudios sobre } \\
\text { Lengua, }\end{array}$ & $\begin{array}{l}\text { 2001-2005, } \\
\text { Salamanca }\end{array}$ & $\begin{array}{l}\text { Antonio } \\
\text { López Eire }\end{array}$ & $\begin{array}{c}1578- \\
455 X \\
\text { (impr.); } \\
1577-5089 \\
\text { (electr.) }\end{array}$ & $\begin{array}{l}\text { Cuatri- } \\
\text { mestral }\end{array}$ & $\begin{array}{l}\text { Ciencias de la } \\
\text { Comunicación, } \\
\text { Lingüistica }\end{array}$ & $\begin{array}{c}\text { http://inter } \\
\text { classica.u } \\
\text { m.es/invest } \\
\text { igacion } / \text { he } \\
\text { meroteca/l/ } \\
\text { logo }\end{array}$ \\
\hline
\end{tabular}




\begin{tabular}{|c|c|c|c|c|c|c|c|}
\hline & $\begin{array}{c}\text { Pensamiento y } \\
\text { Cultura } \\
\text { Clásica }\end{array}$ & & & & & & \\
\hline $\begin{array}{l}\text { 38. Mediaciones } \\
\text { Sociales }\end{array}$ & $\begin{array}{c}\text { Universidad } \\
\text { Complutense } \\
\text { de Madrid / } \\
\text { Grupo de } \\
\text { Investigación } \\
\text { Identidades } \\
\text { Sociales y } \\
\text { Comunicación, } \\
\text { Dep. de } \\
\text { Sociología IV }\end{array}$ & $\begin{array}{l}\text { 2007, } \\
\text { Madrid }\end{array}$ & $\begin{array}{l}\text { Daniel } \\
\text { Franco } \\
\text { Romo }\end{array}$ & 1989-0494 & Semestral & $\begin{array}{l}\text { Sociología, } \\
\text { Ciencias de la } \\
\text { comunicación }\end{array}$ & $\begin{array}{l}\text { https://revi } \\
\text { stas.ucm.e } \\
\text { s/index.ph } \\
\text { p/MESO/ }\end{array}$ \\
\hline $\begin{array}{l}\text { 39. Mediatika. } \\
\text { Cuadernos de } \\
\text { Medios de } \\
\text { Comunicación }\end{array}$ & $\begin{array}{l}\text { Eusko } \\
\text { Ikaskuntza- } \\
\text { Sociedad de } \\
\text { Estudios } \\
\text { Vascos }\end{array}$ & $\begin{array}{l}\text { 1984, San } \\
\text { Sebastián }\end{array}$ & $\begin{array}{c}\text { Jose Ignacio } \\
\text { Aranes } \\
\text { Usandizaga }\end{array}$ & $1137-4462$ & Irregular & $\begin{array}{l}\text { Ciencias de la } \\
\text { Comunicación }\end{array}$ & $\begin{array}{l}\text { http://ww } \\
\text { w.eusko- } \\
\text { ikaskuntza. } \\
\text { org/es/med } \\
\text { iatika }\end{array}$ \\
\hline $\begin{array}{c}\text { 40. Miguel } \\
\text { Hernández } \\
\text { Communication } \\
\text { Journal }\end{array}$ & $\begin{array}{c}\text { Universidad } \\
\text { Miguel } \\
\text { Hernández }\end{array}$ & $\begin{array}{c}2010, \\
\text { Elche } \\
\text { (Alicante) }\end{array}$ & $\begin{array}{l}\text { Montserrat } \\
\text { Jurado } \\
\text { Martín, } \\
\text { Begoña Ivars } \\
\text { Nicolás }\end{array}$ & $1989-8681$ & Anual & $\begin{array}{c}\text { Comunicación en } \\
\text { sus distintas } \\
\text { vertientes: } \\
\text { periodística, } \\
\text { audiovisual y } \\
\text { persuasiva }\end{array}$ & $\begin{array}{l}\text { http://ww } \\
\text { w.mhjourn } \\
\text { al.org/ }\end{array}$ \\
\hline $\begin{array}{l}\text { 41.Obra } \\
\text { Digit@l }\end{array}$ & $\begin{array}{l}\text { Universidad de } \\
\text { Vic, Grupo de } \\
\text { Investigación } \\
\text { Inter-acciones } \\
\text { Digitales del } \\
\text { Dep. de } \\
\text { Comunicación }\end{array}$ & $\begin{array}{c}\text { 2011, } \\
\text { Barcelona }\end{array}$ & $\begin{array}{l}\text { Ruth S. } \\
\text { Contreras }\end{array}$ & 2014-5039 & Semestral & $\begin{array}{l}\text { Investigación de la } \\
\text { Comunicación y } \\
\text { áreas relacionadas: } \\
\text { Comunicación } \\
\text { digital, tendencias, } \\
\text { nuevos desarrollos, } \\
\text { comunicación y } \\
\text { educación, diseño, } \\
\text { marketing y } \\
\text { publicidad digital, } \\
\text { comunicación } \\
\text { móvil y } \\
\text { videojuegos }\end{array}$ & $\begin{array}{l}\text { http://ww } \\
\text { w.obradigi } \\
\text { tal.com/ }\end{array}$ \\
\hline $\begin{array}{l}\text { 42. Pangea (La } \\
\text { Laguna) }\end{array}$ & $\begin{array}{c}\text { Sociedad } \\
\text { Latina de } \\
\text { Comunicación, } \\
\text { Red } \\
\text { Académica } \\
\text { Iberoamerican } \\
\text { a de } \\
\text { Comunicación }\end{array}$ & $\begin{array}{l}2010, \mathrm{La} \\
\text { Laguna } \\
\text { (Tenerife) }\end{array}$ & $\begin{array}{l}\text { Alejandro } \\
\text { Álvarez } \\
\text { Nobell }\end{array}$ & $2172-3168$ & Anual & $\begin{array}{l}\text { Ciencias de la } \\
\text { Comunicación }\end{array}$ & $\begin{array}{c}\text { http://revis } \\
\text { tapangea.o } \\
\text { rg/ }\end{array}$ \\
\hline $\begin{array}{l}\text { 43. Pensar la } \\
\text { publicidad. } \\
\text { Revista } \\
\text { internacional de } \\
\text { investigaciones } \\
\text { publicitarias }\end{array}$ & $\begin{array}{c}\text { Servicios de } \\
\text { Publicaciones } \\
\text { de la } \\
\text { Universidad } \\
\text { Complutense } \\
\text { de Madrid / } \\
\text { Universidad de } \\
\text { Valladolid }\end{array}$ & $\begin{array}{l}\text { 2007, } \\
\text { Segovia }\end{array}$ & $\begin{array}{c}\text { Jesús } \\
\text { Bermejo } \\
\text { Berros y } \\
\text { Antonio } \\
\text { Caro Almela }\end{array}$ & $1887-8598$ & Semestral & $\begin{array}{l}\text { Ciencias de la } \\
\text { Comunicación }\end{array}$ & $\begin{array}{c}\text { https://revi } \\
\text { stas.ucm.e } \\
\text { s/index.ph } \\
\text { p/PEPU }\end{array}$ \\
\hline 44. Periodística & $\begin{array}{c}\text { Societat } \\
\text { Catalana de } \\
\text { Comunicació }\end{array}$ & $\begin{array}{c}1989, \\
\text { Barcelona }\end{array}$ & $\begin{array}{c}\text { Sergi } \\
\text { Cortiñas }\end{array}$ & $\begin{array}{c}1130- \\
183 X \\
\text { (impr.); } \\
2013-9985 \\
\text { (electr.) }\end{array}$ & Anual & $\begin{array}{l}\text { Ciencias de la } \\
\text { Comunicación }\end{array}$ & $\begin{array}{l}\text { http://ww } \\
\text { w.raco.cat/ } \\
\text { index.php/ } \\
\text { Periodistic } \\
\text { a/index }\end{array}$ \\
\hline
\end{tabular}




\begin{tabular}{|c|c|c|c|c|c|c|c|}
\hline $\begin{array}{l}\text { 45. Questiones } \\
\text { publicitarias. } \\
\text { Revista } \\
\text { internacional de } \\
\text { comunicación y } \\
\text { publicidad }\end{array}$ & $\begin{array}{c}\text { Secretariado } \\
\text { de } \\
\text { Publicaciones } \\
\text { de la } \\
\text { Universidad de } \\
\text { Sevilla }\end{array}$ & $\begin{array}{l}\text { 1993, } \\
\text { Sevilla }\end{array}$ & Juan Rey & $1988-8732$ & Anual & $\begin{array}{l}\text { Ciencias de la } \\
\text { comunicación, } \\
\text { Sociología }\end{array}$ & $\begin{array}{l}\text { http://ww } \\
\text { w.maecei.e } \\
\text { s/questione } \\
\text { s_publicita } \\
\text { rias.html }\end{array}$ \\
\hline $\begin{array}{l}\text { 46. Redes.com. } \\
\text { Revista de } \\
\text { Estudios para el } \\
\text { Desarrollo } \\
\text { Social de la } \\
\text { Comunicación }\end{array}$ & $\begin{array}{c}\text { Interdisci- } \\
\text { plinario de } \\
\text { Estudios de } \\
\text { Comunicación, } \\
\text { Política y } \\
\text { Cambio Social } \\
\text { (Compoliticas) } \\
\text { / Instituto } \\
\text { Europeo de } \\
\text { Comunicación } \\
\text { y Desarrollo }\end{array}$ & $\begin{array}{l}\text { 2003, } \\
\text { Sevilla }\end{array}$ & $\begin{array}{l}\text { Francisco } \\
\text { Sierra } \\
\text { Caballero }\end{array}$ & $\begin{array}{l}\text { 1696-2079 } \\
\text { (impr.); } \\
2255-5919 \\
\text { (electr.) }\end{array}$ & Bianual & $\begin{array}{c}\text { Ciencia política y } \\
\text { administración } \\
\text { pública, } \\
\text { Sociología, } \\
\text { Ciencias de la } \\
\text { información, } \\
\text { Ciencias de la } \\
\text { comunicación }\end{array}$ & $\begin{array}{l}\text { http://revis } \\
\text { ta- } \\
\text { redes.com/ }\end{array}$ \\
\hline $\begin{array}{l}\text { 47. Boletín de la } \\
\text { red nacional de } \\
I+D, \text { RedIRIS }\end{array}$ & $\begin{array}{c}\text { Centro de } \\
\text { Comunica- } \\
\text { ciones CSIC } \\
\text { RedIRIS / Red } \\
\text { Nacional de } \\
\text { I+D RedIRIS }\end{array}$ & $\begin{array}{c}\text { 1991-2011, } \\
\text { Madrid }\end{array}$ & $\begin{array}{l}\text { Cristina } \\
\text { Lorenzo }\end{array}$ & $\begin{array}{l}1139- \\
207 X\end{array}$ & $\begin{array}{l}\text { Cuatri- } \\
\text { mestral }\end{array}$ & $\begin{array}{l}\text { Bibliotecología, } \\
\text { Ciencias de la } \\
\text { comunicación, } \\
\text { Ciencias de la } \\
\text { información }\end{array}$ & $\begin{array}{l}\text { http://ww } \\
\text { w.rediris.e } \\
\text { s/difusion/ } \\
\text { publicacio } \\
\text { nes/boletin } \\
/\end{array}$ \\
\hline $\begin{array}{l}\text { 48. Revista de } \\
\text { Comunicación y } \\
\text { Salud }\end{array}$ & $\begin{array}{c}\text { Instituto } \\
\text { Internacional } \\
\text { de } \\
\text { Comunicación } \\
\text { y Salud }\end{array}$ & $\begin{array}{l}\text { 2011, } \\
\text { Madrid }\end{array}$ & $\begin{array}{l}\text { Ubaldo } \\
\text { Cuesta, } \\
\text { Sandra } \\
\text { Gaspar } \\
\text { Herrero }\end{array}$ & $2173-1675$ & Semestral & $\begin{array}{c}\text { Salud pública, } \\
\text { Medicina, Ciencias } \\
\text { de la comunicación }\end{array}$ & $\begin{array}{c}\text { http://ww } \\
\text { w.revistad } \\
\text { ecomunica } \\
\text { cionysalud } \\
\text {.org/index. } \\
\text { php/rcys }\end{array}$ \\
\hline $\begin{array}{l}\text { 49. Revista de la } \\
\text { Asociación } \\
\text { Española de } \\
\text { Investigación de } \\
\text { la } \\
\text { Comunicación: } \\
\text { RAEIC }\end{array}$ & $\begin{array}{c}\text { Asociación } \\
\text { Española de } \\
\text { Investigación } \\
\text { de la } \\
\text { Comunicación } \\
\text { / Universidad } \\
\text { de Santiago de } \\
\text { Compostela }\end{array}$ & $\begin{array}{l}2014, \text { A } \\
\text { Coruña }\end{array}$ & $\begin{array}{c}\text { José Pereira } \\
\text { Fariña, } \\
\text { Carlos } \\
\text { Toural Bran }\end{array}$ & $2341-2690$ & Semestral & $\begin{array}{l}\text { Comunicación } \\
\text { estratégica y } \\
\text { organizacional; } \\
\text { Comunicación y } \\
\text { cultura digital; } \\
\text { Estructura y } \\
\text { políticas de la } \\
\text { comunicación; } \\
\text { Producción y } \\
\text { circulación de } \\
\text { contenidos; } \\
\text { Estudios de } \\
\text { audiencia y } \\
\text { recepción; } \\
\text { Estudios sobre el } \\
\text { discurso: Teorías y } \\
\text { métodos de } \\
\text { investigación en } \\
\text { comunicación }\end{array}$ & $\begin{array}{l}\text { http://ww } \\
\text { w.revistaei } \\
\text { c.org/ }\end{array}$ \\
\hline $\begin{array}{l}\text { 50. Revista de la } \\
\text { SEECI }\end{array}$ & $\begin{array}{c}\text { Universidad } \\
\text { Complutense } \\
\text { de Madrid / } \\
\text { Sociedad } \\
\text { Española de } \\
\text { Estudios de la } \\
\text { Comunicación } \\
\text { Iberoamerican } \\
\text { a }\end{array}$ & $\begin{array}{l}\text { 1997, } \\
\text { Madrid }\end{array}$ & $\begin{array}{l}\text { María } \\
\text { Mendoza } \\
\text { Jorge }\end{array}$ & $1576-3420$ & $\begin{array}{l}\text { Cuatri- } \\
\text { mestral }\end{array}$ & $\begin{array}{l}\text { La sociología, la } \\
\text { comunicación, el } \\
\text { ámbito audiovisual } \\
\text { (cine, televisión, } \\
\text { radio) y las } \\
\text { tecnologías de la } \\
\text { información }\end{array}$ & $\begin{array}{c}\text { http://ww } \\
\text { w.seeci.net } \\
\text { /revista/ind } \\
\text { ex.php/see } \\
\text { ci }\end{array}$ \\
\hline $\begin{array}{l}\text { 51. Revista } \\
\text { Española de } \\
\text { Comunicación } \\
\text { en Salud }\end{array}$ & $\begin{array}{c}\text { Asociación } \\
\text { Española de } \\
\text { Comunicación } \\
\text { Sanitaria }\end{array}$ & $\begin{array}{l}\text { 2010, } \\
\text { Málaga }\end{array}$ & $\begin{array}{l}\text { Miguel } \\
\text { Muñoz- } \\
\text { Cruzado y } \\
\text { Barba }\end{array}$ & $1989-9882$ & Semestral & $\begin{array}{l}\text { Ciencias de la } \\
\text { comunicación, } \\
\text { Salud pública }\end{array}$ & $\begin{array}{l}\text { http://ww } \\
\text { w.aecs.es/r } \\
\text { evista_1_2 } \\
\text {.html }\end{array}$ \\
\hline
\end{tabular}




\begin{tabular}{|c|c|c|c|c|c|c|c|}
\hline $\begin{array}{c}\text { 52. Revista } \\
\text { Estudios } \\
\text { Institucionales }\end{array}$ & $\begin{array}{c}\text { Sociedad de } \\
\text { Estudios } \\
\text { Institucionales }\end{array}$ & $\begin{array}{l}\text { 2014, } \\
\text { Madrid }\end{array}$ & $\begin{array}{l}\text { Dolores del } \\
\text { Mar Sánchez } \\
\text { González }\end{array}$ & $2386-8694$ & Semestral & $\begin{array}{l}\text { Heráldica, } \\
\text { Historia, Derecho } \\
\text { y jurisprudencia, } \\
\text { Ciencias de la } \\
\text { comunicación }\end{array}$ & $\begin{array}{l}\text { http://revis } \\
\text { taeeii.eu/in } \\
\text { dex.php?jo } \\
\text { urnal=revi } \\
\text { staeeii\&pa } \\
\text { ge=index }\end{array}$ \\
\hline $\begin{array}{l}\text { 53. Revista } \\
\text { internacional de } \\
\text { comunicación y } \\
\text { desarrollo }\end{array}$ & $\begin{array}{c}\text { Servizo de } \\
\text { publicacións e } \\
\text { intercambio } \\
\text { científico da } \\
\text { Universidade } \\
\text { de Santiago de } \\
\text { Compostela }\end{array}$ & $\begin{array}{c}2015, \\
\text { Santiago } \\
\text { de } \\
\text { Compostel } \\
\text { a }\end{array}$ & $\begin{array}{l}\text { Marcelo } \\
\text { Antonio } \\
\text { Martínez } \\
\text { Hermida }\end{array}$ & $2386-3730$ & Semestral & $\begin{array}{l}\text { Ciencias sociales y } \\
\text { humanidades, } \\
\text { Ciencias de la } \\
\text { comunicación }\end{array}$ & $\begin{array}{l}\text { http://ww } \\
\text { w.usc.es/re } \\
\text { vistas/inde } \\
\text { x.php/ricd/ } \\
\text { index }\end{array}$ \\
\hline $\begin{array}{l}\text { 54. Revista } \\
\text { Internacional de } \\
\text { Historia de la } \\
\text { Comunicación }\end{array}$ & $\begin{array}{c}\text { Asociación de } \\
\text { Historiadores } \\
\text { de la } \\
\text { Comunicación }\end{array}$ & $\begin{array}{l}\text { 2013, } \\
\text { Sevilla }\end{array}$ & $\begin{array}{l}\text { Antonio } \\
\text { Checa }\end{array}$ & $2255-5129$ & Semestral & $\begin{array}{c}\text { Historia, Ciencias } \\
\text { de la Información, } \\
\text { Ciencias de la } \\
\text { Comunicación }\end{array}$ & $\begin{array}{c}\text { http://revis } \\
\text { tainternaci } \\
\text { onaldehist } \\
\text { oriadelaco } \\
\text { municacio } \\
\text { n.org/ }\end{array}$ \\
\hline $\begin{array}{c}\text { 55. Revista } \\
\text { internacional del } \\
\text { libro, } \\
\text { digitalización y } \\
\text { bibliotecas }\end{array}$ & $\begin{array}{l}\text { Common } \\
\text { Ground } \\
\text { Publisher }\end{array}$ & $\begin{array}{l}\text { 2013-2014, } \\
\text { Madrid }\end{array}$ & $\begin{array}{c}\text { Karim Javier } \\
\text { Gherab } \\
\text { Martín }\end{array}$ & $2255-2871$ & Semestral & $\begin{array}{l}\text { Estudios sobre el } \\
\text { libro y la } \\
\text { influencia de los } \\
\text { nuevos medios } \\
\text { digitales }\end{array}$ & $\begin{array}{l}\text { http://revis } \\
\text { tas.commo } \\
\text { nground- } \\
\text { es.com/ind } \\
\text { ex.php/libr } \\
\text { odigital }\end{array}$ \\
\hline $\begin{array}{l}\text { 56. Revista } \\
\text { Internacional de } \\
\text { Relaciones } \\
\text { Públicas }\end{array}$ & $\begin{array}{c}\text { Instituto de } \\
\text { Investigación } \\
\text { en Relaciones } \\
\text { Públicas }\end{array}$ & $\begin{array}{l}\text { 2011, } \\
\text { Málaga }\end{array}$ & $\begin{array}{l}\text { Ana } \\
\text { Almansa- } \\
\text { Martínez, } \\
\text { Isabel Ruiz- } \\
\text { Mora }\end{array}$ & $2174-3681$ & Semestral & $\begin{array}{l}\text { Comunicación } \\
\text { política, gabinetes } \\
\text { de comunicación, } \\
\text { comunicación } \\
\text { organizacional, } \\
\text { comunicación y } \\
\text { nuevas } \\
\text { tecnologías, } \\
\text { investigación y } \\
\text { evaluación, } \\
\text { responsabilidad } \\
\text { social, } \\
\text { comunicación } \\
\text { turística, gestión } \\
\text { proactiva de } \\
\text { conflictos, } \\
\text { relaciones públicas } \\
\text { internacionales }\end{array}$ & $\begin{array}{c}\text { http://ww } \\
\text { w.revistad } \\
\text { erelaciones } \\
\text { publicas.co } \\
\text { m/ }\end{array}$ \\
\hline $\begin{array}{l}\text { 57. Revista } \\
\text { Latina de } \\
\text { Comunicación } \\
\text { Social }\end{array}$ & $\begin{array}{l}\text { Universidad de } \\
\text { La Laguna }\end{array}$ & $\begin{array}{l}\text { 1998, } \\
\text { Tenerife }\end{array}$ & $\begin{array}{c}\text { José Manuel } \\
\text { de Pablos } \\
\text { Coello }\end{array}$ & $1138-5820$ & $\begin{array}{l}\text { Anual } \\
\text { (desde } \\
2008 \text { ) }\end{array}$ & $\begin{array}{c}\text { Comunicación, } \\
\text { Comunicación } \\
\text { Social }\end{array}$ & $\begin{array}{l}\text { http://ww } \\
\text { w.revistala } \\
\text { tinacs.org/ }\end{array}$ \\
\hline $\begin{array}{l}\text { 58. Revista } \\
\text { Mediterránea de } \\
\text { Comunicación }\end{array}$ & $\begin{array}{l}\text { Universidad de } \\
\text { Alicante }\end{array}$ & $\begin{array}{c}\text { 2010, } \\
\text { Alicante }\end{array}$ & $\begin{array}{l}\text { Victoria Tur } \\
\text { Viñes }\end{array}$ & $\begin{array}{l}1989- \\
872 X\end{array}$ & Semestral & $\begin{array}{l}\text { Comunicación } \\
\text { comercial, } \\
\text { persuasiva, } \\
\text { periodística o } \\
\text { audiovisual }\end{array}$ & $\begin{array}{l}\text { http://ww } \\
\text { w.mediterr } \\
\text { anea- } \\
\text { comunicac } \\
\text { ion.org/Me } \\
\text { diterranea }\end{array}$ \\
\hline $\begin{array}{l}\text { 59. Sphera } \\
\text { Pública }\end{array}$ & $\begin{array}{l}\text { Universidad } \\
\text { Católica San } \\
\text { Antonio de } \\
\text { Murcia } \\
\text { (UCAM) }\end{array}$ & $\begin{array}{l}2000, \\
\text { Murcia }\end{array}$ & $\begin{array}{l}\text { Pablo Blesa } \\
\text { Aledo }\end{array}$ & $1576-4192$ & Irregular & $\begin{array}{l}\text { Ciencias de la } \\
\text { Comunicación }\end{array}$ & $\begin{array}{l}\text { http://sphe } \\
\text { ra.ucam.ed } \\
\text { u/ }\end{array}$ \\
\hline $\begin{array}{l}\text { 60. Teknokul- } \\
\text { tura. Revista de } \\
\text { Cultura Digital y } \\
\text { Movimientos } \\
\text { Sociales }\end{array}$ & $\begin{array}{l}\text { Universidad } \\
\text { Complutense } \\
\text { de Madrid }\end{array}$ & $\begin{array}{l}\text { 2011, } \\
\text { Madrid }\end{array}$ & $\begin{array}{l}\text { Javier de } \\
\text { Rivera, } \\
\text { Sergio } \\
\text { D’Antonio } \\
\text { Maceiras }\end{array}$ & $1549-2230$ & $\begin{array}{l}\text { Cuatri- } \\
\text { mestral }\end{array}$ & $\begin{array}{c}\text { Estudios sociales } \\
\text { de la tecnología y } \\
\text { la cibercultura }\end{array}$ & $\begin{array}{c}\text { http://revis } \\
\text { tas.ucm.es/ } \\
\text { index.php/ } \\
\text { TEKN/abo } \\
\text { ut/ }\end{array}$ \\
\hline
\end{tabular}




\begin{tabular}{|c|c|c|c|c|c|c|c|}
\hline 61. Telos & $\begin{array}{l}\text { Fundación } \\
\text { Telefónica }\end{array}$ & $\begin{array}{l}\text { 1985, } \\
\text { Madrid }\end{array}$ & $\begin{array}{c}\text { Alejandro } \\
\text { Díaz-Garreta }\end{array}$ & $\begin{array}{l}0213- \\
084 X\end{array}$ & $\begin{array}{l}\text { Cuatri- } \\
\text { mestral }\end{array}$ & $\begin{array}{c}\text { Comunicación, } \\
\text { tecnología y } \\
\text { sociedad }\end{array}$ & $\begin{array}{l}\text { https://telo } \\
\text { s.fundacio } \\
\text { ntelefonica } \\
\text {.com }\end{array}$ \\
\hline $\begin{array}{l}\text { 62. Textual \& } \\
\text { Visual Media }\end{array}$ & $\begin{array}{c}\text { Spanish } \\
\text { Journalistic } \\
\text { Society } \\
\text { Journal / } \\
\text { Sociedad } \\
\text { Española de } \\
\text { Periodismo } \\
\text { (SEP) }\end{array}$ & $\begin{array}{l}\text { 2008, } \\
\text { Madrid }\end{array}$ & Concha Edo & $\begin{array}{l}1889-2515 \\
\text { (impr.); } \\
2341-0981 \\
\text { (electr.) }\end{array}$ & Anual & $\begin{array}{l}\text { Estudio del } \\
\text { periodismo en sus } \\
\text { formatos impreso, } \\
\text { audiovisual y } \\
\text { digital }\end{array}$ & $\begin{array}{l}\text { http://textu } \\
\text { alvisualme } \\
\text { dia.com/ }\end{array}$ \\
\hline 63. Trípodos & $\begin{array}{l}\text { Universitat } \\
\text { Ramon Llull }\end{array}$ & $\begin{array}{c}\text { 1996, } \\
\text { Barcelona }\end{array}$ & $\begin{array}{c}\text { Josep María } \\
\text { Carbonell }\end{array}$ & $\begin{array}{c}1138-3305 \\
\text { (impr.), } 23 \\
40-5007 \\
\text { (electr.) }\end{array}$ & Semestral & $\begin{array}{l}\text { Periodismo, cine, } \\
\text { televisión, radio, } \\
\text { publicidad, } \\
\text { relaciones } \\
\text { públicas, internet, } \\
\text { etc. }\end{array}$ & $\begin{array}{c}\text { http://ww } \\
\text { w.tripodos. } \\
\text { com/ }\end{array}$ \\
\hline $\begin{array}{l}\text { 64. Vivat } \\
\text { Academia }\end{array}$ & $\begin{array}{l}\text { FÓRUM XXI } \\
\text { (Asociación } \\
\text { Cultural } \\
\text { Fórum } \\
\text { Internacional } \\
\text { de } \\
\text { Comunicación } \\
\text { y Relaciones } \\
\text { Públicas) }\end{array}$ & $\begin{array}{l}\text { 1998, } \\
\text { Madrid }\end{array}$ & $\begin{array}{l}\text { Luis Solano } \\
\text { Fleta }\end{array}$ & $1575-2844$ & Trimestral & $\begin{array}{l}\text { Comunicación, } \\
\text { Sociología, } \\
\text { Tecnologías de la } \\
\text { Información y } \\
\text { Audiovisuales } \\
\text { (cine, televisión, } \\
\text { radio) }\end{array}$ & $\begin{array}{l}\text { http://ww } \\
\text { w.vivataca } \\
\text { demia.net/ }\end{array}$ \\
\hline $\begin{array}{l}\text { 65. ZER. Revista } \\
\text { de estudios de } \\
\text { comunicación }\end{array}$ & $\begin{array}{c}\text { Universidad } \\
\text { del País Vasco, } \\
\text { Facultad de } \\
\text { Ciencias } \\
\text { Sociales y de } \\
\text { la } \\
\text { Comunicación }\end{array}$ & $\begin{array}{l}\text { 1996, } \\
\text { Bilbao }\end{array}$ & $\begin{array}{c}\text { María } \\
\text { Begoña } \\
\text { Zalbidea } \\
\text { Bengoa }\end{array}$ & $1137-1102$ & Semestral & $\begin{array}{l}\text { Ciencias de la } \\
\text { Comunicación y } \\
\text { Sociología }\end{array}$ & $\begin{array}{c}\text { http://ww } \\
\text { w.ehu.eus/ } \\
\text { zer/ }\end{array}$ \\
\hline
\end{tabular}

Tabla I. Revistas analizadas pertenecientes al Directorio de Latindex, limitadas a la especialidad Comunicación y ámbito geográfico España. Fuente: Elaboración propia a partir de datos de Latindex y de las webs corporativas de las revistas.

\begin{tabular}{|c|c|c|c|c|}
\hline Título de revista & $\begin{array}{l}\text { Número total de } \\
\text { volúmenes publicados } \\
\text { desde su fundación }\end{array}$ & $\begin{array}{l}\text { Número total de } \\
\text { artículos publicados } \\
\text { desde fundación }\end{array}$ & $\begin{array}{l}\text { Número de } \\
\text { artículos que } \\
\text { cumplían los } \\
\text { parámetros de } \\
\text { búsqueda }\end{array}$ & $\begin{array}{l}\text { Año en que se } \\
\text { publica el primer } \\
\text { artículo que } \\
\text { cumplía los } \\
\text { parámetros de } \\
\text { búsqueda }\end{array}$ \\
\hline $\begin{array}{l}\text { 1. AdComunica: Revista } \\
\text { científica de estrategias, } \\
\text { tendencias e innovación en } \\
\text { comunicación }\end{array}$ & 11 & 184 & 2 & 2013 \\
\hline $\begin{array}{l}\text { 2. AdResearch ESIC: Revista } \\
\text { Internacional de Investigación en } \\
\text { Comunicación }\end{array}$ & 12 & 63 & 2 & 2010 \\
\hline $\begin{array}{c}\text { 3. Ambitos. Revista } \\
\text { Internacional de Comunicación }\end{array}$ & 30 & 450 & 2 & 2014 \\
\hline $\begin{array}{l}\text { 4. Anàlisi: Quaderns de } \\
\text { Comunicació i Cultura }\end{array}$ & 53 & 506 & 3 & 1987 \\
\hline 5. Anuarios Thinkepi & 9 & 431 & 0 & \\
\hline 6. Area Abierta & $\begin{array}{c}\text { Hasta el año } 2011 \\
\text { tiene } 30 \text { "Números". A } \\
\text { partir de entonces cambia } \\
\text { a "Volúmenes" (empieza } \\
\text { en el } 12 \text { y ahora van por el } \\
16 \text { ) }\end{array}$ & 223 & 3 & 2006 \\
\hline
\end{tabular}


7. Caleidoscopio: Revista del Audiovisual

8. Catalan Social Sciences Review

9. CIC Cuadernos de Información y Comunicación

10. Commons: Revista de Comunicación y Ciudadanía Digital

11. Communication Papers: Medios de alfabetización y estudios de género

12. Comunicación y Sociedad $=$ Communication $\&$ Society

13. Comunicació. Revista de investigación y análisis

14. Comunicación. Revista Internacional de Comunicación Audiovisual, Publicidad y

Estudios Culturales

15. Comunicación y Estudios Universitarios

16. Comunicación y Hombre.

Revista interdisciplinar de

Ciencias de la Comunicación y Humanidades

17. Comunicar. Revista

Científica de Comunicación y Educación

18. Conexiones. Revista Iberoamericana de Comunicación

19. Derecom. Revista Internacional Online de Derecho de la Comunicación

20. Dígitos. Revista de

Comunicación Digital

21. Doxa. Revista Interdisciplinar de Estudios de Comunicación y Ciencias Sociales

22. El Profesional de la Información. Revista internacional de Información y Comunicación

23. Estudios sobre el mensaje periodistico

24.Etic@net
No se encuentra ninguna base de datos online que incluya sus publicaciones, por lo que no puede efectuarse la búsqueda

\begin{tabular}{|c|c|c|c|}
\hline \multicolumn{4}{|l|}{ busqueda } \\
\hline 5 & 27 & 1 & 2012 \\
\hline 20 & 295 & 2 & 1996 \\
\hline 4 & 40 & 0 & \\
\hline 4 & 62 & 0 & \\
\hline 29 & $\begin{array}{c}483^{*} \\
\text { (consultados en } \\
\text { Dialnet, puesto que } \\
\text { en la web corporativa } \\
\text { no hay información } \\
\text { sobre los artículos } \\
\text { publicados) }\end{array}$ & 8 & 1989 \\
\hline 32 & 411 & 2 & 1998 \\
\hline 13 & 293 & 5 & 2002 \\
\hline 13 & 208 & 3 & 1990 \\
\hline 11 & 127 & 2 & 2009 \\
\hline 24 vol., 46 núm. & 1382 & 5 & 1999 \\
\hline ( & $\begin{array}{l}47 * \text { (consultados } \\
\text { en Dialnet, puesto } \\
\text { que en la web } \\
\text { corporativa no hay } \\
\text { información sobre los } \\
\text { artículos publicados) }\end{array}$ & 0 & \\
\hline $\begin{array}{l}19 * \text { (Dialnet empieza } \\
\text { a contabilizar desde el } \\
\text { Número } 7 \text { ) }\end{array}$ & $\begin{array}{c}125^{*} \text { (sólo los } \\
\text { disponibles en } \\
\text { Dialnet) }\end{array}$ & 1 & 2012 \\
\hline 1 & 11 & 0 & \\
\hline 21 & 2008 & 1 & 2010 \\
\hline 25 & 1.279 & 0 & \\
\hline 21 & 872 & 5 & 2006 \\
\hline 15 & 220 & 0 & \\
\hline
\end{tabular}


25. Eu-topías. Revista de interculturalidad, comunicación y estudios europeos 26. Fonseca. Journal of Communication

27. Formats. Revista de Comunicació Audiovisual

\section{Grafica}

29. Historia y comunicación social

30. I-C. Revista Científica de Información y Comunicación

31. ICONO 14. Revista científica de Comunicación y

Tecnologías emergentes

32. IDP. Revista d'Internet, Dret i Política

33. Index. Comunicación 34. Infoamérica

35. La Comunicación empresarial y la gestión de los intangibles en España y

Latinoamérica

36. Lengcom

37. Logo: Revista de Retórica y Teoría de la

Comunicación

38. Mediaciones Sociales

39. Mediatika. Cuadernos de Medios de Comunicación 40. Miguel Hernández

Communication Journal 41.ObraDigit@l

42. Pangea (La Laguna)

43. Pensar la publicidad. Revista internacional de investigaciones publicitarias 44. Periodística

45. Questiones publicitarias Revista internacional de comunicación y publicidad 46. Redes.com. Revista de Estudios para el Desarrollo Social de la Comunicación 47. Boletín de la red nacional de I+D, RedIRIS

Comunicación y Salud

49. Revista de la Asociación Española de Investigación de la Comunicación: RAEIC

\begin{tabular}{|c|c|c|c|}
\hline 10 & 169 & 0 & \\
\hline 11 & 110 & 3 & 2010 \\
\hline 5 & $\begin{array}{l}67 * \text { (consultados } \\
\text { en Dialnet, puesto } \\
\text { que en la web } \\
\text { corporativa no hay } \\
\text { información sobre los } \\
\text { artículos publicados) }\end{array}$ & 0 & \\
\hline 4 & 32 & 1 & 2014 \\
\hline 20 & 709 & 16 & 1996 \\
\hline 12 & 148 & 4 & 2007 \\
\hline 14 & 460 & 3 & 2009 \\
\hline 21 & 151 & 0 & \\
\hline 9 & 65 & 0 & \\
\hline 9 & 91 & 0 & \\
\hline 17 & $\begin{array}{l}30 *(\text { La web } \\
\text { ofrece únicamente los } \\
\text { resúmenes de } 2013 \text {, } \\
2014 \text { y 2015) }\end{array}$ & 1 & 2014 \\
\hline 11 & $\begin{array}{l}61 * \text { (No se puede } \\
\text { acceder al último } \\
\text { número) }\end{array}$ & 0 & \\
\hline 8 & 117 & 0 & \\
\hline 14 & 135 & 1 & 2009 \\
\hline 14 & 149 & 0 & \\
\hline 7 & 71 & 1 & 2012 \\
\hline 9 & 48 & 0 & \\
\hline 8 & 83 & 0 & \\
\hline 17 & 201 & 5 & 2010 \\
\hline 15 & 125 & 0 & \\
\hline 19 & 298 & 5 & 2007 \\
\hline 11 & 190 & 0 & \\
\hline 90 & $\begin{array}{c}348^{*} \\
\text { (Disponibles desde el } \\
\text { Boletín } \mathrm{n}^{\circ} 35 \text { de } \\
1996)\end{array}$ & 0 & \\
\hline 8 & 22 & 0 & \\
\hline 5 & $\begin{array}{l}20 * \text { (Se consideró } \\
\text { únicamente el cuadro } \\
\text { central })\end{array}$ & 0 & \\
\hline
\end{tabular}




\begin{tabular}{|c|c|c|c|c|}
\hline 50. Revista de la SEECI & 40 & 269 & 6 & 2008 \\
\hline $\begin{array}{l}\text { 51. Revista Española de } \\
\text { Comunicación en Salud }\end{array}$ & 12 & 41 & 0 & \\
\hline $\begin{array}{l}\text { 52. Revista Estudios } \\
\text { institucionales }\end{array}$ & 3 & 20 & 0 & \\
\hline $\begin{array}{l}\text { 53. Revista internacional de } \\
\text { comunicación y desarrollo }\end{array}$ & 5 & 53 & 0 & \\
\hline $\begin{array}{l}\text { 54. Revista Internacional de } \\
\text { Historia de la Comunicación }\end{array}$ & 4 & $\begin{array}{c}28 *(\mathrm{Se} \\
\text { consideraron } \\
\text { únicamente aquellos } \\
\text { en la sección de } \\
\text { Dossier })\end{array}$ & 0 & \\
\hline $\begin{array}{l}\text { 55. Revista internacional del } \\
\text { libro, digitalización y bibliotecas }\end{array}$ & 2 & 25 & 0 & \\
\hline $\begin{array}{l}\text { 56. Revista Internacional de } \\
\text { Relaciones Públicas }\end{array}$ & 10 & $\begin{array}{c}96 *(\mathrm{Se} \\
\text { consideraron } \\
\text { únicamente los que } \\
\text { están en la sección de } \\
\text { Artículos) }\end{array}$ & 5 & 2012 \\
\hline $\begin{array}{l}\text { 57. Revista Latina de } \\
\text { Comunicación Social }\end{array}$ & 71 & $\begin{array}{c}1.154 * \text { (Se } \\
\text { consideró el número } \\
\text { de } 2016 \text { aún estando } \\
\text { en estado de pre- } \\
\text { publicación) }\end{array}$ & 7 & 1998 \\
\hline $\begin{array}{l}\text { 58. Revista Mediterránea de } \\
\text { Comunicación }\end{array}$ & 11 & 107 & 2 & 2011 \\
\hline 59. Sphera Pública & 15 & 206 & 3 & 2013 \\
\hline $\begin{array}{l}\text { 60. Teknokultura. Revista de } \\
\text { Cultura Digital y Movimientos } \\
\text { Sociales }\end{array}$ & 13 & 174 & 0 & 0 \\
\hline 61. Telos & 101 & $\begin{array}{c}647^{*}(\mathrm{Se} \\
\text { consideraron } \\
\text { únicamente los } \\
\text { artículos dentro de la } \\
\text { sección Dossier } \\
\text { Central })\end{array}$ & 4 & 1990 \\
\hline 62. Textual \& Visual Media & 8 & 73 & 2 & 2010 \\
\hline 63. Trípodos & 36 & $\begin{array}{l}\text { 294* (Desde el } \\
\text { Núm. } 18 \text { de } 2006)\end{array}$ & 4 & 2004 \\
\hline 64. Vivat Academia & 133 & 422 & 7 & 2004 \\
\hline $\begin{array}{l}\text { 65. ZER. Revista de estudios } \\
\text { de comunicación }\end{array}$ & 39 & 504 & 6 & 1997 \\
\hline
\end{tabular}

Tabla II. Resultados de la búsqueda de artículos que cumplían con los parámetros de búsqueda. Fuente: Elaboración propia a partir de los datos de las webs corporativas de las revistas. Cuando éstas no ofrecieron suficiente información, también se usaron bases de datos en línea de referencia, como Dialnet.

\begin{tabular}{|c|c|c|c|c|c|c|c|c|}
\hline $\begin{array}{c}\text { Título de la } \\
\text { revista }\end{array}$ & $\begin{array}{l}\text { Título del } \\
\text { artículo }\end{array}$ & Vol. & Año & $\begin{array}{l}\text { Nombre de } \\
\text { los autores }\end{array}$ & $\begin{array}{l}\text { Autores } \\
\text { Masc. }\end{array}$ & $\begin{array}{l}\text { Autores } \\
\text { Fem. }\end{array}$ & $\begin{array}{c}\text { Afiliación de los } \\
\text { autores }\end{array}$ & Idioma \\
\hline $\begin{array}{l}\text { 1. AdResearch } \\
\text { ESIC: Revista } \\
\text { Internacional de } \\
\text { Investigación en } \\
\text { Comunicación }\end{array}$ & $\begin{array}{c}\text { Estrategia de } \\
\text { creación de un } \\
\text { sello de calidad: } \\
\text { Canarias Destino } \\
\text { Familias }\end{array}$ & 1 & 2010 & $\begin{array}{c}\text { Blanca } \\
\text { García } \\
\text { Henche; } \\
\text { Arancha } \\
\text { Mielgo } \\
\text { Álvarez; Eva } \\
\text { Marina } \\
\text { Reinares } \\
\text { Lara; } \\
\text { Manuela } \\
\text { Saco } \\
\text { Vázquez }\end{array}$ & 0 & 4 & $\begin{array}{l}\text { Universidad CEU } \\
\text { San Pablo (3); } \\
\text { Universidad de } \\
\text { Alcalá; } \\
\text { Universidad Rey } \\
\text { Juan Carlos }\end{array}$ & Cast. \\
\hline
\end{tabular}




\begin{tabular}{|c|c|c|c|c|c|c|c|c|}
\hline & $\begin{array}{l}\text { Ciclo de vida de } \\
\text { los destinos } \\
\text { turísticos y } \\
\text { estrategias de } \\
\text { comunicación: los } \\
\text { casos de España y } \\
\text { Chile }\end{array}$ & 7 & 2012 & $\begin{array}{c}\text { Blanca } \\
\text { García } \\
\text { Henche; Eva } \\
\text { Reinares } \\
\text { Lara; } \\
\text { Guillermo } \\
\text { Armelini }\end{array}$ & 1 & 2 & $\begin{array}{l}\text { Universidad de } \\
\text { Alcalá; } \\
\text { Universidad Rey } \\
\text { Juan Carlos; } \\
\text { Universidad de los } \\
\text { Andes }\end{array}$ & Cast. \\
\hline \multirow[t]{2}{*}{$\begin{array}{l}\text { 2. AdComunica: } \\
\text { Revista } \\
\text { científica de } \\
\text { estrategias, } \\
\text { tendencias e } \\
\text { innovación en } \\
\text { comunicación }\end{array}$} & $\begin{array}{l}\text { La fotografía en } \\
\text { la prensa: análisis } \\
\text { comparativo del } \\
\text { tratamiento de las } \\
\text { imágenes de los } \\
\text { terremotos de } \\
\text { Haití (2010) y de } \\
\text { Japón (2011) en } \\
\text { la prensa } \\
\text { española }\end{array}$ & 6 & 2013 & $\begin{array}{l}\text { Jessica } \\
\text { Fernández } \\
\text { Vázquez }\end{array}$ & 0 & 1 & $\begin{array}{c}\text { Universidad de } \\
\text { Vigo }\end{array}$ & Cast. \\
\hline & $\begin{array}{c}\text { Comunicación y } \\
\text { turismo } \\
\text { sostenible. La } \\
\text { emergencia de la } \\
\text { innovación } \\
\text { durante la tarea } \\
\text { de diseño }\end{array}$ & 9 & 2015 & $\begin{array}{l}\text { Arlette } \\
\text { Bouzon; } \\
\text { Jesús } \\
\text { Bermejo } \\
\text { Berros }\end{array}$ & 1 & 1 & $\begin{array}{l}\text { Universidad de } \\
\text { Toulousse III; } \\
\text { Universidad de } \\
\text { Valladolid }\end{array}$ & Cast. \\
\hline \multirow[t]{2}{*}{$\begin{array}{l}\text { 3. Ambitos. } \\
\text { Revista } \\
\text { Internacional de } \\
\text { Comunicación }\end{array}$} & $\begin{array}{l}\text { Publicidad y } \\
\text { Turismo: La } \\
\text { industria del } \\
\text { forastero en la } \\
\text { Exposición } \\
\text { Regional de } \\
\text { Valencia de } 1909\end{array}$ & 19 & 2010 & $\begin{array}{l}\text { Francesc- } \\
\text { Andreu } \\
\text { Martínez } \\
\text { Gallego }\end{array}$ & 1 & 0 & $\begin{array}{l}\text { Universidad de } \\
\text { Valencia }\end{array}$ & Cast. \\
\hline & $\begin{array}{c}\text { Reinventar la } \\
\text { Marca España en } \\
\text { tiempos de crisis: } \\
\text { un análisis } \\
\text { comunicativo de } \\
\text { la campaña } \\
\text { española de } \\
\text { nation branding }\end{array}$ & 24 & 2014 & $\begin{array}{l}\text { Lieve } \\
\text { Vange- } \\
\text { huchten, } \\
\text { Manuela } \\
\text { Crespo }\end{array}$ & 0 & 2 & $\begin{array}{c}\text { Universidad de } \\
\text { Amberes, Bélgica } \\
\text { (2) }\end{array}$ & Cast. \\
\hline \multirow[t]{3}{*}{$\begin{array}{l}\text { 4. Anàlisi: } \\
\text { Quaderns de } \\
\text { Comunicació i } \\
\text { Cultura }\end{array}$} & $\begin{array}{l}\text { La diplomacia de } \\
\text { la dominación } \\
\text { cultural y la libre } \\
\text { circulación de la } \\
\text { información }\end{array}$ & 10 & 1987 & $\begin{array}{l}\text { Herbert I. } \\
\text { Schiller }\end{array}$ & 1 & 0 & No lo especifica & Cast. \\
\hline & $\begin{array}{l}\text { Documental y } \\
\text { nación.com. } \\
\text { Políticas públicas } \\
\text { e identidad: } \\
\text { Québec-Canadá }\end{array}$ & 27 & 2001 & $\begin{array}{l}\text { Margarita } \\
\text { Ledo Andión }\end{array}$ & 0 & 1 & $\begin{array}{l}\text { Universidad de } \\
\text { Santiago de } \\
\text { Compostela }\end{array}$ & Cast. \\
\hline & $\begin{array}{l}\text { Imagen pública } \\
\text { de Cataluña y de } \\
\text { Juan Carlos I en } \\
\text { su primer viaje } \\
\text { como rey en } \\
\text { febrero de } 1976\end{array}$ & 30 & 2003 & $\begin{array}{l}\text { Carlos } \\
\text { Barrera, } \\
\text { Ricardo } \\
\text { Zugasti }\end{array}$ & 2 & 0 & $\begin{array}{l}\text { Universidad de } \\
\text { Navarra (2) }\end{array}$ & Cast. \\
\hline 5. Área Abierta & $\begin{array}{l}\text { El turismo no es } \\
\text { un gran invento: } \\
\text { aperturismo y } \\
\text { recepción del } \\
\text { ocio y consumo a } \\
\text { través del cine } \\
\text { español de los } 60\end{array}$ & 15 & 2006 & $\begin{array}{l}\text { Rafael } \\
\text { Gómez } \\
\text { Alonso }\end{array}$ & 1 & 0 & $\begin{array}{l}\text { Universidad Rey } \\
\text { Juan Carlos }\end{array}$ & Cast. \\
\hline
\end{tabular}




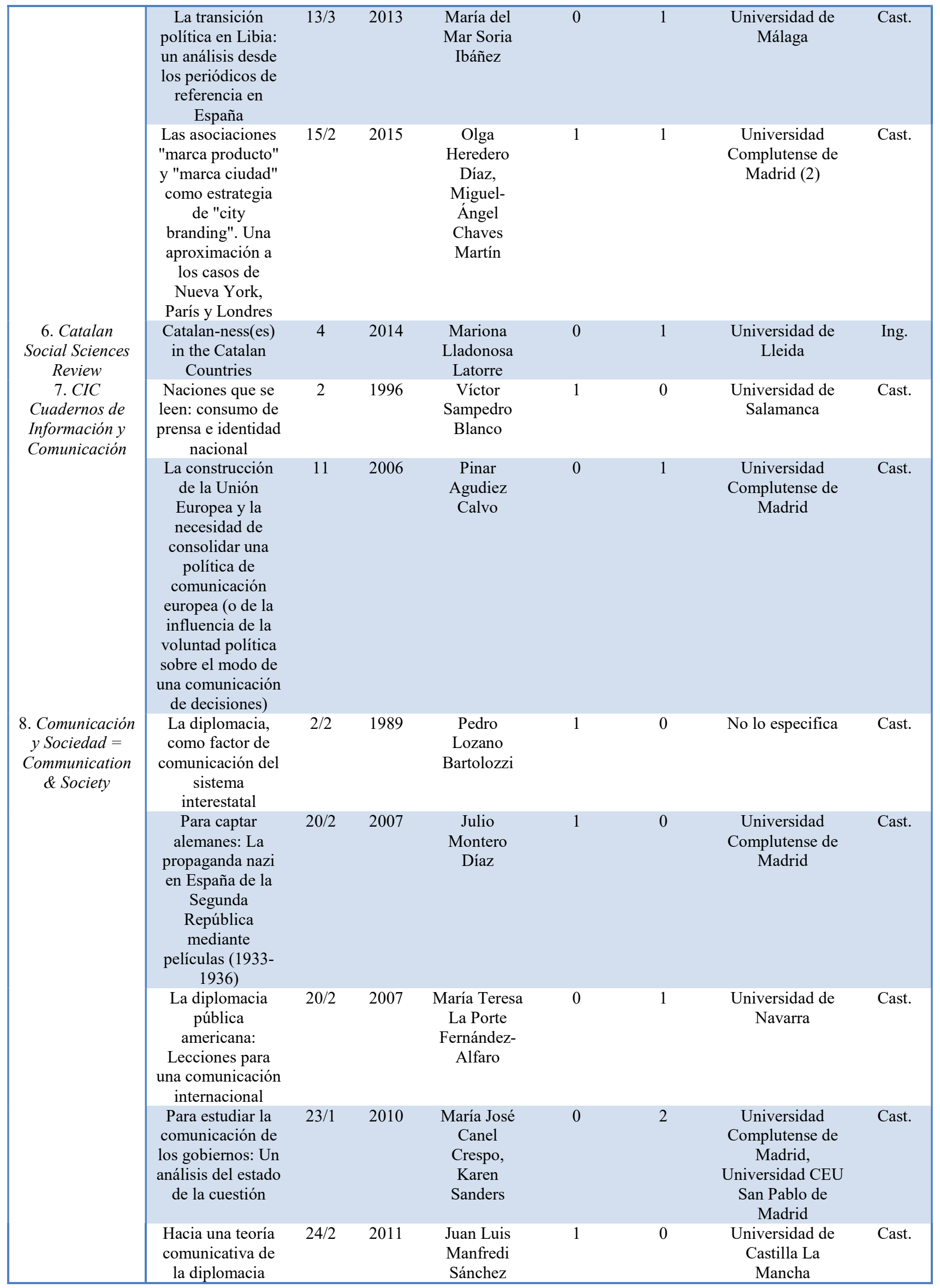




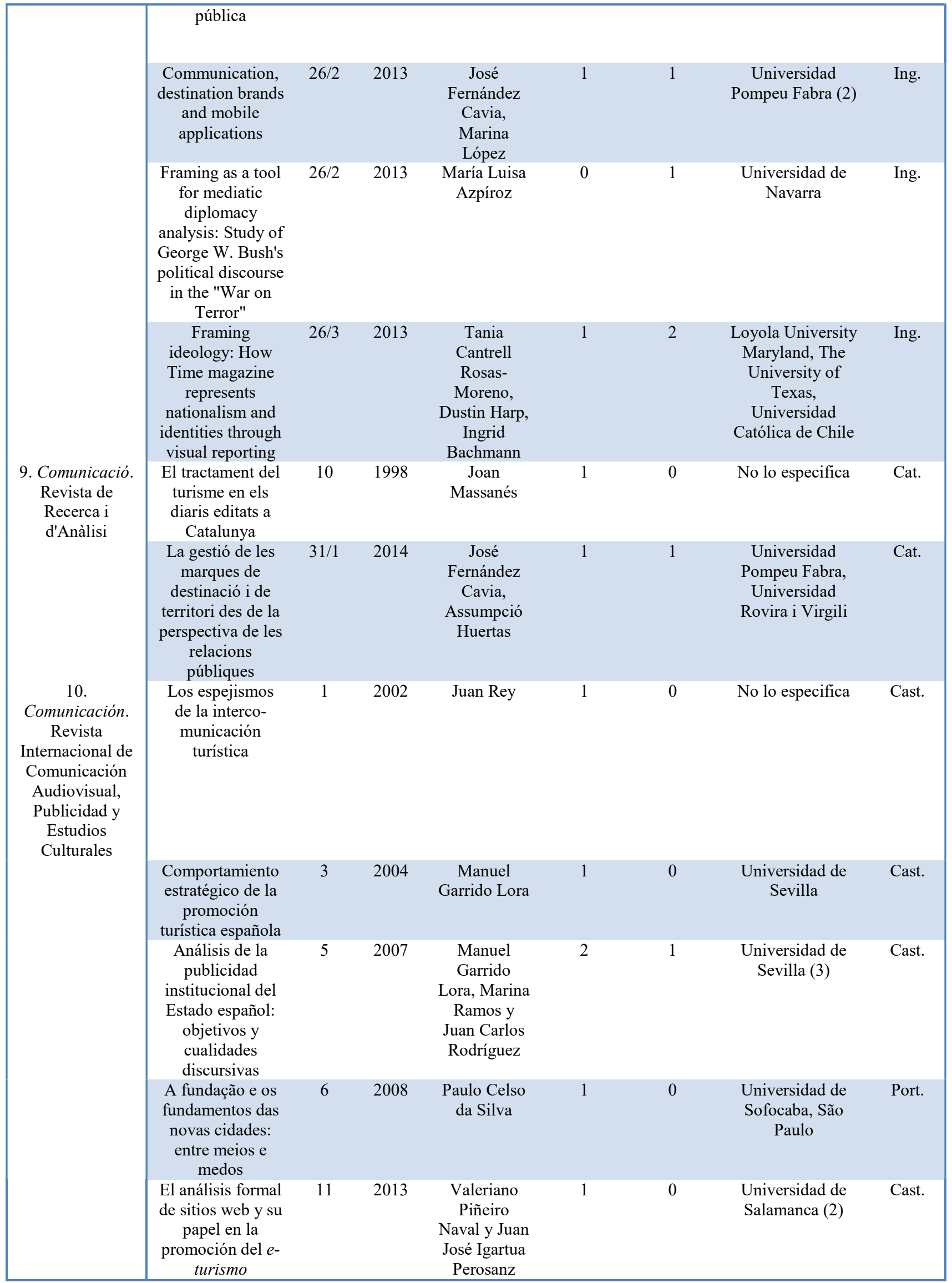




\begin{tabular}{|c|c|c|c|c|c|c|c|c|}
\hline $\begin{array}{c}11 . \\
\text { Comunicación y } \\
\text { Estudios }\end{array}$ & $\begin{array}{l}\text { Islam i món àrab } \\
\text { a l'escola i als } \\
\text { mitjans }\end{array}$ & 8 & 1998 & $\begin{array}{l}\text { Rafael } \\
\text { Miralles } \\
\text { Lucena }\end{array}$ & 1 & 0 & No lo especifica & Cat. \\
\hline & $\begin{array}{c}\text { Diplomacia, } \\
\text { marketing } \\
\text { político y opinión } \\
\text { pública en el viaje } \\
\text { de los reyes a los } \\
\text { Estados Unidos } \\
\text { en junio de } 1976\end{array}$ & 9 & 1999 & $\begin{array}{c}\text { Silvia } \\
\text { Pellicer, } \\
\text { Carlos } \\
\text { Barrera del } \\
\text { Barrio, } \\
\text { María Teresa } \\
\text { La Porte } \\
\text { Fernández- } \\
\text { Alfaro }\end{array}$ & 1 & 2 & $\begin{array}{l}\text { No lo especifica } \\
\text { (3) }\end{array}$ & Cast. \\
\hline & $\begin{array}{l}\text { Nativos y } \\
\text { forasteros: Una } \\
\text { aproximación } \\
\text { antropológica al } \\
\text { turismo de masas }\end{array}$ & 13 & $\begin{array}{l}2004- \\
2005\end{array}$ & $\begin{array}{l}\text { Fernando } \\
\text { Ros Galiana }\end{array}$ & 1 & 0 & No lo especifica & Cast. \\
\hline $\begin{array}{c}12 . \\
\text { Comunicación y } \\
\text { Hombre. Revista } \\
\text { interdisciplinar } \\
\text { de Ciencias de la } \\
\text { Comunicación y } \\
\text { Humanidades }\end{array}$ & $\begin{array}{l}\text { Los contenidos } \\
\text { informativos } \\
\text { territoriales en las } \\
\text { cadenas } \\
\text { generalistas de } \\
\text { radio: la imagen } \\
\text { de Andalucía en } \\
\text { el contexto } \\
\text { informativo } \\
\text { radiofónico } \\
\text { español }\end{array}$ & 5 & 2009 & $\begin{array}{l}\text { Miguel } \\
\text { Ángel Ortiz } \\
\text { Sobrino, } \\
\text { Juan Cuesta } \\
\text { Rico }\end{array}$ & 2 & 0 & $\begin{array}{c}\text { Universidad } \\
\text { Francisco de } \\
\text { Vitoria (2) }\end{array}$ & Cast. \\
\hline & $\begin{array}{l}\text { La diplomacia del } \\
\text { presente: universo } \\
2.0 \text { al alcance de } \\
\text { la mano }\end{array}$ & 9 & 2013 & $\begin{array}{l}\text { Elena Borau } \\
\text { Boira, } \\
\text { Francisco } \\
\text { García } \\
\text { García, } \\
\text { Alfredo } \\
\text { Rodríguez } \\
\text { Gómez }\end{array}$ & 2 & 1 & $\begin{array}{c}\text { Universidad } \\
\text { Complutense de } \\
\text { Madrid (2), } \\
\text { Universidad } \\
\text { Camilo José Cela }\end{array}$ & Cast. \\
\hline $\begin{array}{l}\text { 13. Comunicar. } \\
\text { Revista } \\
\text { Científica de } \\
\text { Comunicación y }\end{array}$ & $\begin{array}{l}\text { La construcción } \\
\text { de estereotipos } \\
\text { andaluces por los } \\
\text { medios }\end{array}$ & 6 & 1999 & $\begin{array}{l}\text { Rafael } \\
\text { González } \\
\text { Galiana }\end{array}$ & 1 & 0 & $\begin{array}{l}\text { Universidad de } \\
\text { Sevilla }\end{array}$ & Cast. \\
\hline & $\begin{array}{l}\text { La doble mirada } \\
\text { sobre Andalucía }\end{array}$ & 6 & 1999 & $\begin{array}{l}\text { Juan José } \\
\text { Fernández } \\
\text { Trevijano }\end{array}$ & 1 & 0 & $\begin{array}{c}\text { Universidad de } \\
\text { Sevilla }\end{array}$ & Cast. \\
\hline & $\begin{array}{l}\text { La ciudad es el } \\
\text { medio, el } \\
\text { territorio es el } \\
\text { mensaje }\end{array}$ & 6 & 1999 & $\begin{array}{l}\text { Josep Lluis } \\
\text { Gómez } \\
\text { Mompart }\end{array}$ & 1 & 0 & $\begin{array}{c}\text { Universidad } \\
\text { Autónoma de } \\
\text { Barcelona }\end{array}$ & Cast. \\
\hline & $\begin{array}{l}\text { La cultura } \\
\text { andaluza en los } \\
\text { libros de texto }\end{array}$ & 7 & 2000 & $\begin{array}{c}\text { Manuel } \\
\text { Hijano del } \\
\text { Río }\end{array}$ & 1 & 0 & $\begin{array}{l}\text { Universidad de } \\
\text { Málaga }\end{array}$ & Cast. \\
\hline & $\begin{array}{l}\text { Andaluces en la } \\
\text { telerrealidad: la } \\
\text { audiencia a través } \\
\text { del estereotipo } \\
\text { del andaluz } \\
\text { anónimo en } \\
\text { televisión }\end{array}$ & 13 & 2005 & $\begin{array}{l}\text { Laura Teruel } \\
\text { Rodríguez, } \\
\text { Florencio } \\
\text { Fernández- } \\
\text { Delgado }\end{array}$ & 1 & 1 & $\begin{array}{l}\text { Universidad de } \\
\text { Málaga (2) }\end{array}$ & Cast. \\
\hline $\begin{array}{l}\text { 14. Derecom. } \\
\text { Revista } \\
\text { Internacional } \\
\text { Online de } \\
\text { Derecho de la } \\
\text { Comunicación }\end{array}$ & $\begin{array}{l}\text { La marca de } \\
\text { destino. El valor } \\
\text { intangible de un } \\
\text { destino y su } \\
\text { protección } \\
\text { jurídica }\end{array}$ & 8 & 2012 & $\begin{array}{l}\text { Mariana } \\
\text { Alba }\end{array}$ & 0 & 1 & No lo especifica & Cast. \\
\hline
\end{tabular}




\begin{tabular}{|c|c|c|c|c|c|c|c|c|}
\hline $\begin{array}{c}\text { 15. Doxa. } \\
\text { Revista } \\
\text { Interdisciplinar } \\
\text { de Estudios de } \\
\text { Comunicación y } \\
\text { Ciencias } \\
\text { Sociales }\end{array}$ & $\begin{array}{c}\text { Teoría de la } \\
\text { comunicación y } \\
\text { paisaje. Las } \\
\text { geografías del } \\
\text { sujeto y la } \\
\text { perspectiva } \\
\text { interpretativa de } \\
\text { la comunicación }\end{array}$ & 10 & 2010 & $\begin{array}{l}\text { Joan Nogué, } \\
\text { Jordi de San } \\
\text { Eugenio }\end{array}$ & 2 & 0 & $\begin{array}{l}\text { Universidad de } \\
\text { Girona, } \\
\text { Universidad de } \\
\text { Vic }\end{array}$ & Cast. \\
\hline \multirow[t]{5}{*}{$\begin{array}{l}\text { 16. Estudios } \\
\text { sobre el mensaje } \\
\text { periodístico }\end{array}$} & $\begin{array}{l}\text { La comunicación } \\
\text { institucional y de } \\
\text { servicios. Las } \\
\text { páginas web } \\
\text { municipales de } \\
\text { las capitales de } \\
\text { provincia } \\
\text { españolas }\end{array}$ & 12 & 2006 & $\begin{array}{c}\text { María del } \\
\text { Mar } \\
\text { Rodríguez } \\
\text { González, } \\
\text { Íñigo } \\
\text { Marauri } \\
\text { Castillo, } \\
\text { Jesús Ángel } \\
\text { Pérez da } \\
\text { Silva }\end{array}$ & 2 & 1 & $\begin{array}{l}\text { Universidad del } \\
\text { País Vasco (3) }\end{array}$ & Cast. \\
\hline & $\begin{array}{c}\text { Las redes sociales } \\
\text { en las marcas } \\
\text { turísticas de la } \\
\text { Comunidad } \\
\text { Valenciana }\end{array}$ & 18 & 2012 & $\begin{array}{l}\text { Mar Iglesias } \\
\text { García, } \\
\text { María } \\
\text { Dolores } \\
\text { Fernández } \\
\text { Poyatos }\end{array}$ & 0 & 2 & $\begin{array}{l}\text { Universidad de } \\
\text { Alicante (2) }\end{array}$ & Cast. \\
\hline & $\begin{array}{c}\text { La comunicación } \\
\text { como instrumento } \\
\text { de la diplomacia } \\
\text { pública }\end{array}$ & 19 & 2013 & $\begin{array}{l}\text { Alfredo A. } \\
\text { Rodríguez } \\
\text { Gómez }\end{array}$ & 1 & 0 & $\begin{array}{c}\text { Universidad } \\
\text { Camilo José Cela }\end{array}$ & Cast. \\
\hline & $\begin{array}{c}\text { La construcción } \\
\text { de la marca } \\
\text { 'Qatar' a partir } \\
\text { del deporte: } \\
\text { 'sports place } \\
\text { branding' y } \\
\text { prensa deportiva } \\
\text { catalana }\end{array}$ & 19 & 2013 & $\begin{array}{l}\text { Jordi de San } \\
\text { Eugenio } \\
\text { Vela, Xavier } \\
\text { Ginesta } \\
\text { Portet }\end{array}$ & 2 & 0 & $\begin{array}{l}\text { Universidad de } \\
\text { Vic (2) }\end{array}$ & Cast. \\
\hline & $\begin{array}{c}\text { Medios de } \\
\text { comunicación y } \\
\text { marcas turísticas: } \\
\text { la labor de las } \\
\text { oficinas } \\
\text { extranjeras de } \\
\text { turismo en } \\
\text { España }\end{array}$ & 20 & 2014 & $\begin{array}{c}\text { Beatriz } \\
\text { González } \\
\text { Santos, José } \\
\text { Fernández } \\
\text { Cavia, } \\
\text { Daniel Tena } \\
\text { Parera }\end{array}$ & 2 & 1 & $\begin{array}{c}\text { Universidad } \\
\text { Pompeu Fabra (2), } \\
\text { Universidad } \\
\text { Autónoma de } \\
\text { Barcelona }\end{array}$ & Cast. \\
\hline \multirow[t]{3}{*}{$\begin{array}{l}\text { 17. Fonseca. } \\
\text { Journal of } \\
\text { Communication }\end{array}$} & $\begin{array}{l}\text { La imagen de la } \\
\text { Unión Europea y } \\
\text { de sus países } \\
\text { miembros en la } \\
\text { prensa oficial } \\
\text { china Xinhua } \\
\text { online: Un } \\
\text { estudio empírico }\end{array}$ & 1 & 2010 & $\begin{array}{l}\text { Lifen Cheng, } \\
\text { Potseng } \\
\text { Chen, } \\
\text { Shiany } \\
\text { Pérez-Cheng }\end{array}$ & 0 & 3 & $\begin{array}{l}\text { No lo especifica } \\
\text { (3) }\end{array}$ & Cast. \\
\hline & $\begin{array}{c}\text { El estereotipo } \\
\text { como mecanismo } \\
\text { de desintegración } \\
\text { de la identidad } \\
\text { nacional. El caso } \\
\text { de Mi gran boda } \\
\text { griega }\end{array}$ & 2 & 2011 & $\begin{array}{l}\text { José Félix } \\
\text { González } \\
\text { Sánchez }\end{array}$ & 1 & 0 & No lo especifica & Cast. \\
\hline & $\begin{array}{l}\text { El nacionalismo } \\
\text { polaco a través de } \\
\text { la película Kanal }\end{array}$ & 4 & 2014 & VVAA & $?$ & $?$ & $\begin{array}{l}\text { Universidad de } \\
\text { Salamanca (?), } \\
\text { Universidad de } \\
\text { Valladolid (?) }\end{array}$ & Cast. \\
\hline 18. Grafica & $\begin{array}{l}\text { La catalanitat a } \\
\text { les marques de }\end{array}$ & 2 & 2014 & $\begin{array}{c}\text { Berta Cantó } \\
\text { Gargallo }\end{array}$ & 0 & 1 & No lo especifica & Cat. \\
\hline
\end{tabular}




\begin{tabular}{|c|c|c|c|c|c|c|c|c|}
\hline \multirow{11}{*}{$\begin{array}{l}\text { 19. Historia y } \\
\text { comunicación } \\
\text { social }\end{array}$} & \multicolumn{8}{|l|}{ begudes catalanes } \\
\hline & $\begin{array}{l}\text { Las relaciones } \\
\text { diplomáticas } \\
\text { entre España y } \\
\text { México a través } \\
\text { del cónsul } \\
\text { Agustín de } \\
\text { Letamendi (1839- } \\
1842)\end{array}$ & 1 & 1996 & $\begin{array}{l}\text { María } \\
\text { Antonia } \\
\text { Fernández } \\
\text { Jiménez }\end{array}$ & 0 & 1 & No lo especifica & Cast. \\
\hline & $\begin{array}{l}\text { 1898: Apuntes } \\
\text { sobre la } \\
\text { diplomacia } \\
\text { internacional y la } \\
\text { opinión pública }\end{array}$ & 3 & 1998 & $\begin{array}{c}\text { Ingrid } \\
\text { Schulze } \\
\text { Scheneider }\end{array}$ & 0 & 1 & $\begin{array}{l}\text { Universidad } \\
\text { Complutense de } \\
\text { Madrid }\end{array}$ & Cast. \\
\hline & $\begin{array}{c}\text { Intervención } \\
\text { extranjera y } \\
\text { propaganda. La } \\
\text { propaganda } \\
\text { exterior de las dos } \\
\text { Españas }\end{array}$ & 6 & 2001 & $\begin{array}{l}\text { Alejandro } \\
\text { Pizarroso } \\
\text { Quintero }\end{array}$ & 1 & 0 & No lo especifica & Cast. \\
\hline & $\begin{array}{l}\text { Las rutas de } \\
\text { guerra y los } \\
\text { periodistas } \\
\text { portugueses }\end{array}$ & 6 & 2001 & $\begin{array}{l}\text { Beatriz } \\
\text { Correyero } \\
\text { Ruiz }\end{array}$ & 0 & 1 & No lo especifica & Cast. \\
\hline & $\begin{array}{l}\text { Propaganda } \\
\text { turística y estatal } \\
\text { en España a } \\
\text { través de sellos y } \\
\text { billetes }\end{array}$ & 7 & 2002 & $\begin{array}{l}\text { Beatriz } \\
\text { Correyero } \\
\text { Ruiz }\end{array}$ & 0 & 1 & No lo especifica & Cast. \\
\hline & $\begin{array}{l}\text { Proyecto para un } \\
\text { Nuevo Siglo } \\
\text { Americano y la } \\
\text { ideologización de } \\
\text { la Diplomacia } \\
\text { estadounidense }\end{array}$ & 10 & 2005 & $\begin{array}{c}\text { María } \\
\text { Paulina } \\
\text { Correa } \\
\text { Burrows }\end{array}$ & 0 & 1 & $\begin{array}{l}\text { Universidad } \\
\text { Nacional de } \\
\text { Educación a } \\
\text { Distancia }\end{array}$ & Cast. \\
\hline & $\begin{array}{c}\text { Relaciones } \\
\text { internacionales y } \\
\text { estrategias de } \\
\text { comunicación de } \\
\text { la España de } \\
\text { Franco ante la } \\
\text { coyuntura de } \\
1956\end{array}$ & 12 & 2007 & $\begin{array}{l}\text { Matilde } \\
\text { Eiroa San } \\
\text { Francisco }\end{array}$ & 0 & 1 & $\begin{array}{l}\text { Universidad } \\
\text { Carlos III de } \\
\text { Madrid }\end{array}$ & Cast. \\
\hline & $\begin{array}{c}\text { Una } \\
\text { aproximación a la } \\
\text { imagen cultural } \\
\text { de España a } \\
\text { través de sus } \\
\text { tópicos históricos } \\
\text { y literarios más } \\
\text { significativos }\end{array}$ & 14 & 2009 & $\begin{array}{c}\text { Gema Cano } \\
\text { Jiménez }\end{array}$ & 0 & 1 & $\begin{array}{l}\text { Universidad } \\
\text { Carlos III de } \\
\text { Madrid }\end{array}$ & Cast. \\
\hline & $\begin{array}{c}\text { Deporte e } \\
\text { identidad, o sobre } \\
\text { cómo definirnos }\end{array}$ & 17 & 2012 & $\begin{array}{l}\text { Francisco } \\
\text { Javier } \\
\text { Caspistegui }\end{array}$ & 1 & 0 & $\begin{array}{l}\text { Universidad de } \\
\text { Navarra }\end{array}$ & Cast. \\
\hline & $\begin{array}{l}\text { De la propaganda } \\
\text { franquista a la } \\
\text { Marca España: } 70 \\
\text { años de Radio } \\
\text { Exterior de } \\
\text { España }\end{array}$ & 18 & 2013 & $\begin{array}{l}\text { Miguel } \\
\text { Ángel Ortiz } \\
\text { Sobrino }\end{array}$ & 1 & 0 & $\begin{array}{l}\text { Universidad } \\
\text { Complutense de } \\
\text { Madrid }\end{array}$ & Cast. \\
\hline
\end{tabular}




\begin{tabular}{|c|c|c|c|c|c|c|c|c|}
\hline & $\begin{array}{l}\text { Comunicación e } \\
\text { historia al } \\
\text { servicio de la } \\
\text { proyección } \\
\text { territorial: la } \\
\text { imagen oriental } \\
\text { de la ciudad de } \\
\text { Granada }\end{array}$ & 18 & 2013 & $\begin{array}{c}\text { Estela } \\
\text { Bernad } \\
\text { Monferrer, } \\
\text { Zeynep } \\
\text { Arda, César } \\
\text { Fernández } \\
\text { Fernández }\end{array}$ & 1 & 2 & $\begin{array}{l}\text { Universidad } \\
\text { Jaume I (2), Izmir } \\
\text { University of } \\
\text { Economics } \\
\text { (Turkey) }\end{array}$ & Cast. \\
\hline & $\begin{array}{l}\text { La imagen de la } \\
\text { Marca España en } \\
\text { las redes a través } \\
\text { de su campaña "I } \\
\text { need Spain"" }\end{array}$ & 19 & 2014 & $\begin{array}{l}\text { Juan Manuel } \\
\text { Corbacho } \\
\text { Valencia, } \\
\text { Mónica } \\
\text { Valderrama } \\
\text { Santomé, } \\
\text { Silvia García } \\
\text { Mirón }\end{array}$ & 1 & 2 & $\begin{array}{c}\text { Universidad de } \\
\text { Vigo (3) }\end{array}$ & Cast. \\
\hline & $\begin{array}{l}\text { Publicidad y } \\
\text { relaciones } \\
\text { públicas en la } \\
\text { promoción } \\
\text { turística del } \\
\text { Patronato Costa } \\
\text { Blanca. } 2008- \\
2010\end{array}$ & 19 & 2014 & $\begin{array}{c}\text { María } \\
\text { Dolores } \\
\text { Fernández } \\
\text { Poyatos, } \\
\text { Ainhoa } \\
\text { Aguirre- } \\
\text { goitia } \\
\text { Martínez }\end{array}$ & 0 & 2 & $\begin{array}{l}\text { Universidad de } \\
\text { Alicante (2) }\end{array}$ & Cast. \\
\hline & $\begin{array}{c}\text { De la marca } \\
\text { comercial a la } \\
\text { marca de } \\
\text { territorio. Los } \\
\text { casos de la DOC } \\
\text { Priorat y DO } \\
\text { Montsant }\end{array}$ & 19 & 2014 & $\begin{array}{l}\text { Jordi de San } \\
\text { Eugenio } \\
\text { Vela, Xavier } \\
\text { Ginesta } \\
\text { Portet, } \\
\text { Salvador } \\
\text { Simó Algado }\end{array}$ & 3 & 0 & $\begin{array}{c}\text { Universidad de } \\
\text { Vic (3) }\end{array}$ & Cast. \\
\hline & $\begin{array}{l}\text { El orgullo patrio } \\
\text { como estrategia } \\
\text { comunicativa en } \\
\text { tiempos de crisis }\end{array}$ & 19 & 2014 & $\begin{array}{l}\text { Francisco } \\
\text { Cabezuelo- } \\
\text { Lorenzo }\end{array}$ & 1 & 0 & $\begin{array}{l}\text { Universidad de } \\
\text { Valladolid } \\
\text { (Campus de } \\
\text { Segovia) }\end{array}$ & Cast. \\
\hline & $\begin{array}{l}\text { Taxonomía de la } \\
\text { diplomacia digital } \\
\text { en la agenda de } \\
\text { las nuevas } \\
\text { relaciones } \\
\text { internacionales }\end{array}$ & 19 & 2014 & $\begin{array}{l}\text { Juan Luis } \\
\text { Manfredi } \\
\text { Sánchez }\end{array}$ & 1 & 0 & $\begin{array}{l}\text { Universidad de } \\
\text { Castilla La } \\
\text { Mancha }\end{array}$ & Cast. \\
\hline \multirow[t]{4}{*}{$\begin{array}{l}\text { 20. I-C. Revista } \\
\text { Científica de } \\
\text { Información y } \\
\text { Comunicación }\end{array}$} & $\begin{array}{l}\text { La percepción de } \\
\text { la realidad } \\
\text { española en el } \\
\text { imaginario } \\
\text { colectivo del } \\
\text { inmigrante }\end{array}$ & 4 & 2007 & $\begin{array}{l}\text { María } \\
\text { Eugenia } \\
\text { González } \\
\text { Cortés }\end{array}$ & 0 & 1 & $\begin{array}{c}\text { Universidad de } \\
\text { Málaga }\end{array}$ & Cast. \\
\hline & $\begin{array}{c}\text { La prensa, la } \\
\text { ventana hacia } \\
\text { mundos exóticos. } \\
\text { Imaginarios } \\
\text { visuales pasados } \\
\text { y presentes sobre } \\
\text { las otras culturas }\end{array}$ & 4 & 2007 & $\begin{array}{c}\text { Estela } \\
\text { Rodríguez }\end{array}$ & 0 & 1 & $\begin{array}{l}\text { Universidad } \\
\text { Autónoma de } \\
\text { Barcelona }\end{array}$ & Cast. \\
\hline & $\begin{array}{c}\text { Internet e } \\
\text { identidad } \\
\text { nacional: Estado, } \\
\text { dominios y } \\
\text { comunidades } \\
\text { virtuales }\end{array}$ & 7 & 2010 & Alvar Peris & 1 & 0 & $\begin{array}{c}\text { Universidad de } \\
\text { Valencia }\end{array}$ & Cast. \\
\hline & $\begin{array}{c}\text { Sobre a } \\
\text { identidade } \\
\text { brasileira }\end{array}$ & 7 & 2010 & Muniz Sodré & 1 & 0 & $\begin{array}{c}\text { Universidad } \\
\text { Federal de Rio de } \\
\text { Janeiro }\end{array}$ & Port. \\
\hline
\end{tabular}




\begin{tabular}{|c|c|c|c|c|c|c|c|c|}
\hline \multirow[t]{3}{*}{$\begin{array}{l}\text { 21. ICONO } 14 . \\
\text { Revista } \\
\text { científica de } \\
\text { Comunicación y } \\
\text { Tecnologías } \\
\text { emergentes }\end{array}$} & $\begin{array}{l}\text { El Tercer Mundo } \\
\text { representado: La } \\
\text { imagen como } \\
\text { nido de } \\
\text { estereotipos }\end{array}$ & $7 / 2$ & 2009 & $\begin{array}{c}\text { Rebeca } \\
\text { Martín Nieto }\end{array}$ & 0 & 1 & $\begin{array}{l}\text { Universidad Rey } \\
\text { Juan Carlos }\end{array}$ & Cast. \\
\hline & $\begin{array}{l}\text { Notoriedad de la } \\
\text { comunicación } \\
\text { institucional a } \\
\text { través de la } \\
\text { diplomacia }\end{array}$ & $8 / 2$ & 2010 & $\begin{array}{l}\text { Ricardo Ruíz } \\
\text { de la Serna }\end{array}$ & 1 & 0 & $\begin{array}{c}\text { Universidad CEU } \\
\text { San Pablo }\end{array}$ & Cast. \\
\hline & $\begin{array}{l}\text { El viaje y sus } \\
\text { relatos. Una } \\
\text { aproximación a la } \\
\text { construcción de la } \\
\text { imagen de la } \\
\text { ciudad histórica }\end{array}$ & $10 / 2$ & 2012 & $\begin{array}{c}\text { Miguel } \\
\text { Ángel } \\
\text { Chaves } \\
\text { Martín }\end{array}$ & 1 & 0 & $\begin{array}{l}\text { Universidad } \\
\text { Complutense de } \\
\text { Madrid }\end{array}$ & Cast. \\
\hline $\begin{array}{c}\text { 22. La } \\
\text { Comunicación } \\
\text { empresarial y la } \\
\text { gestión de los } \\
\text { intangibles en } \\
\text { España y } \\
\text { Latino-américa }\end{array}$ & $\begin{array}{l}\text { La marca España } \\
\text { desde la teoría de } \\
\text { la reputación }\end{array}$ & 16 & 2014 & $\begin{array}{c}\text { Justo } \\
\text { Villafañe }\end{array}$ & 1 & 0 & $\begin{array}{l}\text { Universidad } \\
\text { Complutense de } \\
\text { Madrid }\end{array}$ & Cast. \\
\hline $\begin{array}{l}\text { 23. Mediaciones } \\
\text { Sociales }\end{array}$ & $\begin{array}{l}\text { La construcción } \\
\text { de la imagen } \\
\text { exterior de } \\
\text { España desde su } \\
\text { política cultural }\end{array}$ & 4 & 2009 & $\begin{array}{l}\text { Gema Cano } \\
\text { Jiménez }\end{array}$ & 0 & 1 & $\begin{array}{c}\text { Universidad } \\
\text { Carlos III de } \\
\text { Madrid }\end{array}$ & Cast. \\
\hline \multirow{5}{*}{$\begin{array}{l}\text { 24. Miguel } \\
\text { Hernández } \\
\text { Communication } \\
\text { Journal } \\
\text { 25. Pensar la } \\
\text { publicidad. } \\
\text { Revista } \\
\text { internacional de } \\
\text { investigaciones } \\
\text { publicitarias }\end{array}$} & $\begin{array}{l}\text { Marketing del } \\
\text { enoturismo en la } \\
\text { web } 2.0\end{array}$ & 3 & 2012 & $\begin{array}{l}\text { Mónica } \\
\text { Matellanes } \\
\text { Lazo }\end{array}$ & 0 & 1 & $\begin{array}{c}\text { Universidad } \\
\text { Europea Miguel } \\
\text { de Cervantes de } \\
\text { Valladolid }\end{array}$ & Cast. \\
\hline & $\begin{array}{c}\text { Reposiciona- } \\
\text { miento de la } \\
\text { imagen turística } \\
\text { de Brujas a través } \\
\text { del cine: de } \\
\text { ciudad de cuento } \\
\text { a ciudad de } \\
\text { thriller }\end{array}$ & $4 / 1$ & 2010 & $\begin{array}{l}\text { Salvador } \\
\text { Martínez } \\
\text { Puche }\end{array}$ & 1 & 0 & $\begin{array}{c}\text { Universidad San } \\
\text { Jorge }\end{array}$ & Cast. \\
\hline & $\begin{array}{l}\text { Marketing para } \\
\text { ciudades: las } \\
\text { ciudades también } \\
\text { se venden, las } \\
\text { ciudades también } \\
\text { son productos }\end{array}$ & $4 / 1$ & 2010 & $\begin{array}{l}\text { José Sixto } \\
\text { García }\end{array}$ & 1 & 0 & $\begin{array}{l}\text { Universidad de } \\
\text { Santiago de } \\
\text { Compostela }\end{array}$ & Cast. \\
\hline & $\begin{array}{l}\text { La marca } \\
\text { territorio como } \\
\text { elemento de la } \\
\text { comunicación: } \\
\text { Factor estratégico } \\
\text { del desarrollo } \\
\text { turístico en } \\
\text { Cuenca }\end{array}$ & $7 / 1$ & 2013 & $\begin{array}{l}\text { Cristina } \\
\text { González } \\
\text { Oñate, Sonia } \\
\text { Martínez } \\
\text { Bueno }\end{array}$ & 0 & 2 & $\begin{array}{c}\text { Universidad } \\
\text { Jaume I de } \\
\text { Castellón, } \\
\text { Fundación de } \\
\text { Cultura Ciudad de } \\
\text { Cuenca }\end{array}$ & Cast. \\
\hline & $\begin{array}{c}\text { Estrategias de } \\
\text { «city placement» } \\
\text { (emplazamiento } \\
\text { de ciudades en el } \\
\text { cine) en la } \\
\text { promoción del } \\
\text { turismo español. } \\
\text { El caso de } \\
\text { Zindagi Na } \\
\text { Milegi Dobara }\end{array}$ & $8 / 2$ & 2014 & $\begin{array}{l}\text { Alfonso } \\
\text { Méndiz } \\
\text { Noguerol }\end{array}$ & 1 & 0 & $\begin{array}{c}\text { Universitat } \\
\text { Internacional de } \\
\text { Catalunya }\end{array}$ & Cast. \\
\hline
\end{tabular}




\begin{tabular}{|c|c|c|c|c|c|c|c|c|}
\hline \multirow{3}{*}{$\begin{array}{l} \\
\text { 26. Questiones } \\
\text { publicitarias. } \\
\text { Revista } \\
\text { internacional de } \\
\text { comunicación y } \\
\text { publicidad }\end{array}$} & \multicolumn{8}{|l|}{$\begin{array}{l}\text { (Sólo se vive una } \\
\text { vez, 2011) }\end{array}$} \\
\hline & $\begin{array}{l}\text { Análisis jurídico } \\
\text { de la publicidad } \\
\text { institucional: } \\
\text { estudio de los } \\
\text { bienes propuestos } \\
\text { en la campaña } \\
\text { Marca Perú }\end{array}$ & $8 / 2$ & 2014 & $\begin{array}{c}\text { Claudia Solís } \\
\text { Hoyos, } \\
\text { Tomás } \\
\text { Ricardo } \\
\text { Atarama } \\
\text { Rojas }\end{array}$ & 1 & 1 & $\begin{array}{l}\text { Universidad de } \\
\text { Piura (2) }\end{array}$ & Cast. \\
\hline & $\begin{array}{l}\text { La construcción } \\
\text { de la imagen } \\
\text { turística de un } \\
\text { territorio a } \\
\text { través de la } \\
\text { publicidad }\end{array}$ & $12 / 1$ & 2007 & $\begin{array}{l}\text { Carmen } \\
\text { María } \\
\text { Alonso } \\
\text { Fernández }\end{array}$ & 0 & 1 & $\begin{array}{l}\text { Universidad } \\
\text { Pontificia de } \\
\text { Salamanca }\end{array}$ & Cast. \\
\hline & $\begin{array}{l}\text { Eficacia de las } \\
\text { campañas } \\
\text { publicitarias: El } \\
\text { caso de las } \\
\text { campañas de } \\
\text { turismo del } \\
\text { Gobierno Vasco }\end{array}$ & $14 / 1$ & 2009 & $\begin{array}{l}\text { Elena } \\
\text { Olabarri } \\
\text { Fernández, } \\
\text { Miguel } \\
\text { Angel } \\
\text { Quintana }\end{array}$ & 1 & 1 & $\begin{array}{l}\text { Universidad del } \\
\text { País Vasco (2) }\end{array}$ & Cast. \\
\hline & $\begin{array}{l}\text { Cuestiones sobre } \\
\text { la representación } \\
\text { audiovisual de la } \\
\text { nueva Andalucía. } \\
\text { De la amistad al } \\
\text { amor: Campaña } \\
\text { Andalucía te } \\
\text { quiere (2008) }\end{array}$ & $14 / 1$ & 2009 & $\begin{array}{l}\text { Virginia } \\
\text { Guarinos }\end{array}$ & 0 & 1 & $\begin{array}{l}\text { Universidad de } \\
\text { Sevilla }\end{array}$ & Cast. \\
\hline & $\begin{array}{c}\text { Hacia la } \\
\text { globalización del } \\
\text { tópico andaluz: } \\
\text { Andalucía te } \\
\text { quiere }\end{array}$ & $17 / 1$ & 2012 & $\begin{array}{l}\text { Cinta M. } \\
\text { Cano } \\
\text { Figueroa }\end{array}$ & 0 & 1 & $\begin{array}{l}\text { Universidad de } \\
\text { Sevilla }\end{array}$ & Cast. \\
\hline & $\begin{array}{l}\text { La web como } \\
\text { herramienta de } \\
\text { comunicación y } \\
\text { distribución de } \\
\text { destinos } \\
\text { turísticos. } \\
\text { Análisis y } \\
\text { modelos }\end{array}$ & $18 / 1$ & 2013 & $\begin{array}{l}\text { Pablo Díaz- } \\
\text { Luque, } \\
\text { Gloria } \\
\text { Jiménez } \\
\text { Marín }\end{array}$ & 1 & 1 & $\begin{array}{c}\text { Universidad Pablo } \\
\text { de Olavide, } \\
\text { Universidad de } \\
\text { Sevilla }\end{array}$ & Cast. \\
\hline \multirow[t]{4}{*}{$\begin{array}{l}\text { 27. Revista de la } \\
\text { SEECI }\end{array}$} & $\begin{array}{l}\text { Social Media en } \\
\text { el sector del } \\
\text { enoturismo }\end{array}$ & 34 & 2014 & $\begin{array}{l}\text { Mónica } \\
\text { Matellanes } \\
\text { Lazo }\end{array}$ & 0 & 1 & $\begin{array}{c}\text { Universidad } \\
\text { Europea Miguel } \\
\text { de Cervantes de } \\
\text { Valladolid }\end{array}$ & Cast. \\
\hline & $\begin{array}{l}\text { Micro-cluster y } \\
\text { nuevo turista }\end{array}$ & 23 & 2010 & $\begin{array}{l}\text { Amélie } \\
\text { Fiorello }\end{array}$ & 0 & 1 & $\begin{array}{c}\text { Universidad Nice } \\
\text { Sophia-Antipolis. } \\
\text { Niza }\end{array}$ & Fran. \\
\hline & $\begin{array}{l}\text { Clusters y redes } \\
\text { empresariales en } \\
\text { el contexto del } \\
\text { turismo rural: la } \\
\text { experiencia } \\
\text { griega }\end{array}$ & 23 & 2010 & $\begin{array}{l}\text { Marios } \\
\text { Soteriades }\end{array}$ & 1 & 0 & $\begin{array}{l}\text { TEI de Creta, } \\
\text { Heraklion, Creta }\end{array}$ & Fran. \\
\hline & $\begin{array}{l}\text { Dinámica de } \\
\text { competencias y } \\
\text { creación de un } \\
\text { clusters de } \\
\text { turismo } \\
\text { sostenible: el caso } \\
\text { de cinco tierras }\end{array}$ & 22 & 2010 & $\begin{array}{c}\text { Corinne Van } \\
\text { der Yeugh }\end{array}$ & 0 & 1 & $\begin{array}{l}\text { Université du Sud } \\
\text { Toulon-Var } \\
\text { (Francia) }\end{array}$ & Fran. \\
\hline
\end{tabular}




\begin{tabular}{|c|c|c|c|c|c|c|c|c|}
\hline \multirow[t]{5}{*}{$\begin{array}{l}\text { 28. Revista } \\
\text { Internacional de } \\
\text { Relaciones } \\
\text { Públicas }\end{array}$} & $\begin{array}{c}\text { Relaciones } \\
\text { Públicas 2.0. El } \\
\text { uso de los medios } \\
\text { sociales en la } \\
\text { estrategia de } \\
\text { comunicación } \\
\text { online de marcas } \\
\text { ciudad }\end{array}$ & 3 & 2012 & $\begin{array}{c}\text { María José } \\
\text { Ramos Ostio }\end{array}$ & 0 & 1 & $\begin{array}{l}\text { Universidad de } \\
\text { Málaga }\end{array}$ & Cast. \\
\hline & $\begin{array}{c}\text { La información } \\
\text { publicada en la } \\
\text { prensa } \\
\text { internacional } \\
\text { como elemento } \\
\text { configurador de } \\
\text { la imagen de los } \\
\text { países }\end{array}$ & 5 & 2013 & $\begin{array}{l}\text { María } \\
\text { Antonia } \\
\text { Strauck } \\
\text { Franco }\end{array}$ & 0 & 1 & $\begin{array}{l}\text { Universidad } \\
\text { Peruana de } \\
\text { Ciencias } \\
\text { Aplicadas, Perú }\end{array}$ & Cast. \\
\hline & $\begin{array}{l}\text { Nuevos desafíos } \\
\text { en relaciones } \\
\text { públicas } 2.0 . \mathrm{La} \\
\text { creciente } \\
\text { influencia de las } \\
\text { plataformas de } \\
\text { online review en } \\
\text { turismo }\end{array}$ & 7 & 2014 & $\begin{array}{l}\text { Susana } \\
\text { Wichels }\end{array}$ & 0 & 1 & $\begin{array}{l}\text { Universidad de } \\
\text { Coimbra, Portugal }\end{array}$ & Cast. \\
\hline & $\begin{array}{l}\text { Estrategia de } \\
\text { medios y place } \\
\text { branding en la } \\
\text { región } \\
\text { transnacional } \\
\text { europea de } \\
\text { Öresund }\end{array}$ & 8 & 2014 & $\begin{array}{c}\text { Jasper } \\
\text { Falkheimer }\end{array}$ & 1 & 0 & $\begin{array}{l}\text { Lun University, } \\
\text { Sweden }\end{array}$ & Cast. \\
\hline & $\begin{array}{c}\text { El comienzo del } \\
\text { turismo español. } \\
\text { Una } \\
\text { aproximación a } \\
\text { los precedentes } \\
\text { de las relaciones } \\
\text { públicas } \\
\text { institucionales } \\
(1900-1950)\end{array}$ & 10 & 2015 & $\begin{array}{l}\text { Natalia } \\
\text { Rodríguez } \\
\text { Salcedo }\end{array}$ & 0 & 1 & $\begin{array}{l}\text { Universidad de } \\
\text { Navarra }\end{array}$ & Cast. \\
\hline \multirow[t]{4}{*}{$\begin{array}{l}\text { 29. Revista } \\
\text { Latina de } \\
\text { Comunicación } \\
\text { Social }\end{array}$} & $\begin{array}{c}\text { Promoción } \\
\text { turística a través } \\
\text { del sector } \\
\text { audiovisual. El } \\
\text { caso de Canarias }\end{array}$ & 9 & 1998 & $\begin{array}{c}\text { María Teresa } \\
\text { Sandoval } \\
\text { Martín }\end{array}$ & 0 & 1 & $\begin{array}{c}\text { Universidad de La } \\
\text { Laguna }\end{array}$ & Cast. \\
\hline & $\begin{array}{l}\text { Una promoción } \\
\text { turística y un } \\
\text { gabinete de } \\
\text { comunicación que } \\
\text { falla }\end{array}$ & 49 & 2002 & $\begin{array}{c}\text { María A. } \\
\text { Gabino } \\
\text { Campos }\end{array}$ & 0 & 1 & $\begin{array}{c}\text { Universidad de La } \\
\text { Laguna }\end{array}$ & Cast. \\
\hline & $\begin{array}{c}\text { Hacia un } \\
\text { producto integral: } \\
\text { campaña } \\
\text { promocional de } \\
\text { Canarias durante } \\
\text { los JJ.OO. de } \\
1996\end{array}$ & 50 & 2002 & $\begin{array}{c}\text { María A. } \\
\text { Gabino } \\
\text { Campos }\end{array}$ & 0 & 1 & $\begin{array}{c}\text { Universidad de La } \\
\text { Laguna }\end{array}$ & Cast. \\
\hline & $\begin{array}{l}\text { La estrategia } \\
\text { creativa en la } \\
\text { publicidad } \\
\text { turística. El caso } \\
\text { de Castilla y León }\end{array}$ & 63 & 2008 & $\begin{array}{l}\text { Alonso } \\
\text { González, } \\
\text { Carmen } \\
\text { María }\end{array}$ & 1 & 1 & $\begin{array}{l}\text { Universidad de La } \\
\text { Laguna (2) }\end{array}$ & Cast. \\
\hline
\end{tabular}




\begin{tabular}{|c|c|c|c|c|c|c|c|c|}
\hline & $\begin{array}{l}\text { Características y } \\
\text { funciones para } \\
\text { marcas de lugar a } \\
\text { partir de un } \\
\text { método Delphi }\end{array}$ & 68 & 2013 & $\begin{array}{l}\text { Jordi de San } \\
\text { Eugenio } \\
\text { Vela, José } \\
\text { Fernández- } \\
\text { Cavia, Joan } \\
\text { Nogué, } \\
\text { Monika } \\
\text { Jiménez- } \\
\text { Morales }\end{array}$ & 3 & 1 & $\begin{array}{c}\text { Universidad de } \\
\text { Vic, Universidad } \\
\text { Pompeu Fabra (2), } \\
\text { Universidad de } \\
\text { Girona }\end{array}$ & Cast. \\
\hline & $\begin{array}{l}\text { Marcas de destino } \\
\text { y evaluación de } \\
\text { sitios web: una } \\
\text { metodología de } \\
\text { investigación }\end{array}$ & 68 & 2013 & $\begin{array}{c}\text { José } \\
\text { Fernández- } \\
\text { Cavia, Pablo } \\
\text { Díaz-Luque, } \\
\text { Assumpció } \\
\text { Huertas, } \\
\text { Cristòfol } \\
\text { Rovira, } \\
\text { Rafael } \\
\text { Pedraza- } \\
\text { Jimenez, } \\
\text { María } \\
\text { Sicilia, } \\
\text { Lorena } \\
\text { Gómez, M.a } \\
\text { Isabel } \\
\text { Míguez }\end{array}$ & 4 & 4 & $\begin{array}{c}\text { Universidad } \\
\text { Pompeu Fabra (4), } \\
\text { Universidad Pablo } \\
\text { de Olavide (1), } \\
\text { Universidad } \\
\text { Rovira i Virgili } \\
\text { (1), Universidad } \\
\text { de Murcia (1), } \\
\text { Universidad de } \\
\text { Vigo (1) }\end{array}$ & Cast. \\
\hline & $\begin{array}{l}\text { La televisión y la } \\
\text { creación de una } \\
\text { nueva identidad } \\
\text { española en la } \\
\text { Transición } \\
(1976-1979)\end{array}$ & 71 & 2016 & $\begin{array}{l}\text { Virginia } \\
\text { Martín } \\
\text { Jiménez, } \\
\text { Itziar } \\
\text { Reguero } \\
\text { Sanz, José } \\
\text { Vidal Pelaz } \\
\text { López }\end{array}$ & 1 & 2 & $\begin{array}{l}\text { Universidad de } \\
\text { Valladolid (3) }\end{array}$ & Cast. \\
\hline \multirow[t]{2}{*}{$\begin{array}{l}\text { 30. Sphera } \\
\text { Pública }\end{array}$} & $\begin{array}{c}\text { Percepción } \\
\text { Interna y Externa } \\
\text { de la Imagen de } \\
\text { la Marca de } \\
\text { España: Análisis } \\
\text { de Métodos de } \\
\text { Evaluación }\end{array}$ & $\begin{array}{l}\mathrm{N}^{\mathrm{o}} \\
\text { Esp. }\end{array}$ & 2014 & $\begin{array}{l}\text { Juan Manuel } \\
\text { Corbacho } \\
\text { Valencia, } \\
\text { María Isabel } \\
\text { Míguez } \\
\text { González, } \\
\text { Mónica } \\
\text { Valderrama } \\
\text { Santomé }\end{array}$ & 1 & 2 & $\begin{array}{l}\text { Universidad de } \\
\text { Vigo (3) }\end{array}$ & Cast. \\
\hline & $\begin{array}{c}\text { Uso y Utilidades } \\
\text { De Las } \\
\text { Herramientas De } \\
\text { Análisis Online } \\
\text { Para La } \\
\text { Evaluación De La } \\
\text { Comunicación De } \\
\text { Las Marcas De } \\
\text { Destino A Través } \\
\text { De Los Social } \\
\text { Media }\end{array}$ & $\begin{array}{l}\mathrm{N}^{\mathrm{o}} \\
\text { Esp. }\end{array}$ & 2014 & $\begin{array}{l}\text { Assumpció } \\
\text { Huertas } \\
\text { Roig, Estela } \\
\text { Mariné Roig }\end{array}$ & 0 & 2 & $\begin{array}{c}\text { Universidad } \\
\text { Rovira i Virgili } \\
\text { (2) }\end{array}$ & Cast. \\
\hline \multirow[t]{3}{*}{ 31. Telos } & $\begin{array}{l}\text { Los MOOC como } \\
\text { herramientas de } \\
\text { diplomacia } \\
\text { pública }\end{array}$ & 101 & 2015 & $\begin{array}{l}\text { Juan Luis } \\
\text { Manfredi- } \\
\text { Sánchez y } \\
\text { Francisco } \\
\text { Cabezuelo- } \\
\text { Lorenzo }\end{array}$ & 2 & 0 & $\begin{array}{l}\text { IE University, } \\
\text { Universidad de } \\
\text { Valladolid }\end{array}$ & Cast. \\
\hline & $\begin{array}{l}\text { El podcast como } \\
\text { guía turística }\end{array}$ & 93 & 2012 & $\begin{array}{l}\text { Israel V. } \\
\text { Márquez }\end{array}$ & 2 & 1 & $\begin{array}{l}\text { Universidad } \\
\text { Complutense de } \\
\text { Madrid (3) }\end{array}$ & Cast. \\
\hline & Identidad europea & 23 & 1990 & Philip & 1 & 0 & Universidad de & Cast. \\
\hline
\end{tabular}




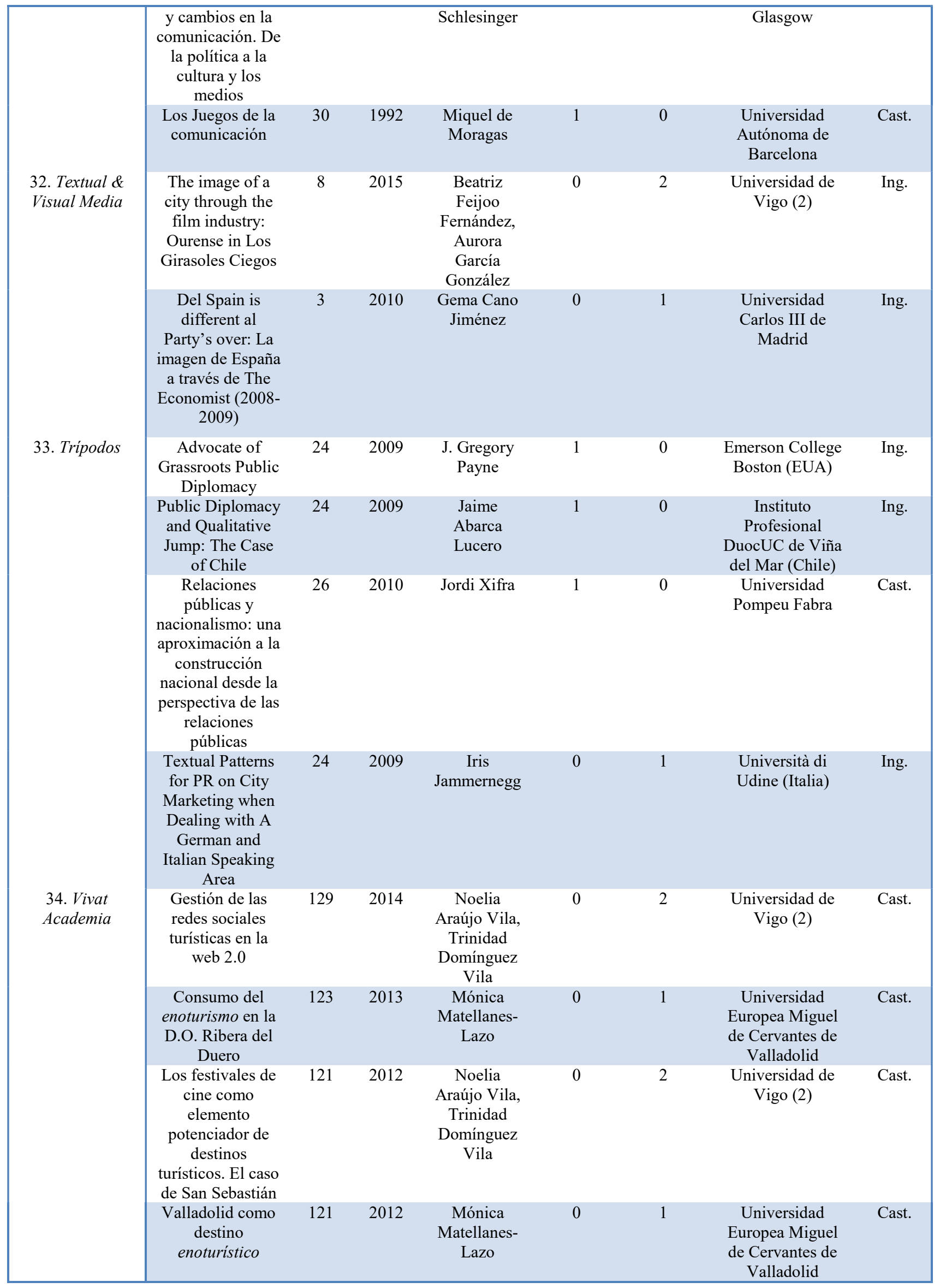




\begin{tabular}{|c|c|c|c|c|c|c|c|c|}
\hline \multirow{4}{*}{$\begin{array}{l}\text { 35. ZER. Revista } \\
\text { de estudios de } \\
\text { comunicación }\end{array}$} & $\begin{array}{l}\text { Comparativa de } \\
\text { contenidos } \\
\text { enoturísticos en } \\
\text { la web } 2.0\end{array}$ & 120 & 2012 & $\begin{array}{l}\text { Mónica } \\
\text { Matellanes- } \\
\text { Lazo }\end{array}$ & 0 & 1 & $\begin{array}{c}\text { Universidad } \\
\text { Europea Miguel } \\
\text { de Cervantes de } \\
\text { Valladolid }\end{array}$ & Cast. \\
\hline & $\begin{array}{l}\text { El laberíntico } \\
\text { caso del Fauno. A } \\
\text { propósito de la } \\
\text { identidad } \\
\text { nacional de las } \\
\text { películas }\end{array}$ & 34 & 2013 & $\begin{array}{l}\text { Imanol } \\
\text { Zumalde }\end{array}$ & 1 & 0 & $\begin{array}{l}\text { Universidad del } \\
\text { País Vasco }\end{array}$ & Cast. \\
\hline & $\begin{array}{l}\text { Las ferias } \\
\text { profesionales en } \\
\text { Galicia: eventos } \\
\text { de relaciones } \\
\text { públicas como } \\
\text { ejemplos de } \\
\text { acciones de } \\
\text { comunicación } \\
\text { below the line }\end{array}$ & 29 & 2010 & $\begin{array}{l}\text { Ana Belén } \\
\text { Fernández } \\
\text { Souto, } \\
\text { Montse } \\
\text { Vázquez } \\
\text { Gestal }\end{array}$ & 0 & 2 & $\begin{array}{l}\text { Universidad de } \\
\text { Vigo (2) }\end{array}$ & Cast. \\
\hline & $\begin{array}{c}\text { Identidad } \\
\text { territorial y } \\
\text { promoción } \\
\text { turística: la } \\
\text { organización de } \\
\text { eventos como } \\
\text { estrategia de } \\
\text { creación, } \\
\text { consolidación y } \\
\text { difusión de la } \\
\text { imagen de marca } \\
\text { del territorio }\end{array}$ & 26 & 2009 & $\begin{array}{l}\text { Mónika } \\
\text { Jiménez } \\
\text { Morales, } \\
\text { Jordi de San } \\
\text { Eugenio } \\
\text { Vela }\end{array}$ & 1 & 1 & $\begin{array}{c}\text { Universitat } \\
\text { Pompeu Fabra, } \\
\text { Universidad de } \\
\text { Vic }\end{array}$ & Cast. \\
\hline
\end{tabular}

Tabla III. Relación de las revistas con los artículos seleccionados, volumen y año en que se publicaron, nombre y sexo de los autores, su afiliación institucional e idioma del texto. Fuente: Elaboración propia.

\begin{tabular}{|c|c|c|c|c|c|}
\hline Título del artículo & $\begin{array}{l}\text { Tema central } \\
\text { del artículo }\end{array}$ & $\begin{array}{l}\text { Metodología } \\
\text { empleada }\end{array}$ & $\begin{array}{c}\text { Tipo de muestra } \\
\text { empleada }\end{array}$ & $\begin{array}{l}\text { Territorio } \\
\text { objeto de } \\
\text { estudio }\end{array}$ & Palabras clave \\
\hline $\begin{array}{c}\text { Estrategia de creación } \\
\text { de un sello de calidad: } \\
\text { Canarias Destino } \\
\text { Familias }\end{array}$ & $\begin{array}{l}\text { Estrategias de } \\
\text { creación de } \\
\text { sellos turísticos }\end{array}$ & $\begin{array}{l}\text { Encuesta personal } \\
\text { con cuestionario } \\
\text { estructurado }\end{array}$ & $\begin{array}{c}\text { Unidades } \\
\text { familiares de } \\
\text { turistas en Canarias }\end{array}$ & $\begin{array}{l}\text { Islas } \\
\text { Canarias } \\
\text { (España) }\end{array}$ & $\begin{array}{l}\text { Sello de calidad, } \\
\text { Marcas de garantía, } \\
\text { Segmentación turística, } \\
\text { Turismo familiar, } \\
\text { Diferenciación turística }\end{array}$ \\
\hline $\begin{array}{l}\text { Ciclo de vida de los } \\
\text { destinos turísticos y } \\
\text { estrategias de } \\
\text { comunicación: los } \\
\text { casos de España y } \\
\text { Chile }\end{array}$ & $\begin{array}{l}\text { Ciclo de vida de } \\
\text { los destinos } \\
\text { turísticos }\end{array}$ & Estudio de caso & $\begin{array}{l}\text { Destino turístico en } \\
\text { cuestión }\end{array}$ & $\begin{array}{l}\text { España y } \\
\text { Chile }\end{array}$ & $\begin{array}{l}\text { Ciclo de vida del } \\
\text { destino turístico, } \\
\text { estrategias de } \\
\text { comunicación del } \\
\text { destino turístico, } \\
\text { estrategias de } \\
\text { posicionamiento del } \\
\text { destino turístico }\end{array}$ \\
\hline $\begin{array}{l}\text { La fotografía en la } \\
\text { prensa: análisis } \\
\text { comparativo del } \\
\text { tratamiento de las } \\
\text { imágenes de los } \\
\text { terremotos de Haití } \\
\text { (2010) y de Japón } \\
\text { (2011) en la prensa } \\
\text { española }\end{array}$ & $\begin{array}{l}\text { Tratamiento y } \\
\text { cobertura } \\
\text { mediática de los } \\
\text { países }\end{array}$ & $\begin{array}{l}\text { Análisis formal y } \\
\text { de contenido }\end{array}$ & $\begin{array}{l}\text { Fotografias de los } \\
\text { periódicos } \\
\text { españoles }(A B C, E l \\
\text { Mundo y El País) }\end{array}$ & Haití y Japón & $\begin{array}{l}\text { Análisis fotográfico, } \\
\text { terremoto Haití, } \\
\text { tsunami Japón, ética } \\
\text { informativa, fotografía } \\
\text { en prensa, fotonoticia }\end{array}$ \\
\hline
\end{tabular}




\begin{tabular}{|c|c|c|c|c|c|}
\hline $\begin{array}{l}\text { Comunicación y } \\
\text { turismo sostenible. La } \\
\text { emergencia de la } \\
\text { innovación durante la } \\
\text { tarea de diseño }\end{array}$ & $\begin{array}{c}\text { La } \\
\text { comunicación } \\
\text { en la innovación } \\
\text { del diseño } \\
\text { turístico }\end{array}$ & $\begin{array}{l}\text { Observación } \\
\text { participante }\end{array}$ & $\begin{array}{c}\text { Empresas del } \\
\text { sector turístico (2 } \\
\text { PYMES } \\
\text { independientes y } 2 \\
\text { agencias de viajes) }\end{array}$ & Francia & $\begin{array}{l}\text { Innovación, diseño, } \\
\text { turismo, emergencia, } \\
\text { decisión en situación, } \\
\text { comunicación }\end{array}$ \\
\hline $\begin{array}{l}\text { Publicidad y Turismo: } \\
\text { La industria del } \\
\text { forastero en la } \\
\text { Exposición Regional de } \\
\text { Valencia de } 1909\end{array}$ & $\begin{array}{l}\text { Promoción } \\
\text { turística a } \\
\text { principios del } \\
\text { siglo XX }\end{array}$ & Estudio histórico & Datos secundarios & $\begin{array}{l}\text { Valencia } \\
\text { (España) }\end{array}$ & $\begin{array}{c}\text { Turismo, propaganda, } \\
\text { publicidad, } \\
\text { comunicación } \\
\text { corporativa, } \\
\text { exposiciones }\end{array}$ \\
\hline $\begin{array}{l}\text { Reinventar la Marca } \\
\text { España en tiempos de } \\
\text { crisis: un análisis } \\
\text { comunicativo de la } \\
\text { campaña española de } \\
\text { nation branding }\end{array}$ & $\begin{array}{l}\text { Análisis del } \\
\text { impacto de } \\
\text { imágenes } \\
\text { negativas en } \\
\text { nation branding }\end{array}$ & $\begin{array}{l}\text { Análisis de } \\
\text { contenido }\end{array}$ & Marca España & España & $\begin{array}{c}\text { Marca España, imagen } \\
\text { de España, identidad } \\
\text { competitiva, nation } \\
\text { branding, } \\
\text { comunicación } \\
\text { mercadotécnica }\end{array}$ \\
\hline $\begin{array}{l}\text { La diplomacia de la } \\
\text { dominación cultural y } \\
\text { la libre circulación de } \\
\text { la información }\end{array}$ & $\begin{array}{l}\text { La diplomacia } \\
\text { pública }\end{array}$ & $\begin{array}{c}\text { Revisión } \\
\text { bibliográfica }\end{array}$ & Datos secundarios & $\begin{array}{l}\text { Estados } \\
\text { Unidos de } \\
\text { América }\end{array}$ & No hay \\
\hline $\begin{array}{c}\text { Documental y } \\
\text { nación.com. Políticas } \\
\text { públicas e identidad: } \\
\text { Québec-Canadá }\end{array}$ & $\begin{array}{c}\text { Imagen } \\
\text { documental de } \\
\text { país }\end{array}$ & $\begin{array}{l}\text { Revisión } \\
\text { bibliográfica y } \\
\text { documental }\end{array}$ & $\begin{array}{l}\text { Documentos } \\
\text { visuales, } \\
\text { hemerográficos y } \\
\text { bibliográficos de la } \\
\text { Cinemathèque } \\
\text { Québécoise }\end{array}$ & $\begin{array}{l}\text { Québec } \\
\text { (Canadá) }\end{array}$ & $\begin{array}{l}\text { Documental, nación, } \\
\text { cinéma verité, } \\
\text { subjetividad }\end{array}$ \\
\hline $\begin{array}{l}\text { Imagen pública de } \\
\text { Cataluña y de Juan } \\
\text { Carlos I en su primer } \\
\text { viaje como rey en } \\
\text { febrero de } 1976\end{array}$ & $\begin{array}{l}\text { Imagen pública } \\
\text { de un territorio }\end{array}$ & $\begin{array}{l}\text { Análisis de } \\
\text { contenido }\end{array}$ & $\begin{array}{c}\text { Periódicos } \\
\text { españoles (5 } \\
\text { editados en Madrid } \\
\text { y } 5 \text { en Barcelona) }\end{array}$ & $\begin{array}{l}\text { Cataluña } \\
\text { (España) }\end{array}$ & $\begin{array}{l}\text { Historia de la } \\
\text { comunicación, } \\
\text { transición política, } \\
\text { Cataluña, España, } \\
\text { monarquía }\end{array}$ \\
\hline $\begin{array}{l}\text { El turismo no es un } \\
\text { gran invento: } \\
\text { aperturismo y } \\
\text { recepción del ocio y } \\
\text { consumo a través del } \\
\text { cine español de los } 60\end{array}$ & $\begin{array}{l}\text { Imagen del } \\
\text { turista en los } \\
\text { medios }\end{array}$ & $\begin{array}{l}\text { Análisis de } \\
\text { contenido }\end{array}$ & $\begin{array}{c}\text { Turistas que } \\
\text { aparecen en las } \\
\text { películas españolas } \\
\text { de los años '60 }\end{array}$ & España & $\begin{array}{l}\text { Cine, Turismo, } \\
\text { Representación } \\
\text { Audiovisual }\end{array}$ \\
\hline $\begin{array}{l}\text { La transición política } \\
\text { en Libia: un análisis } \\
\text { desde los periódicos de } \\
\text { referencia en España }\end{array}$ & $\begin{array}{l}\text { Tratamiento y } \\
\text { cobertura } \\
\text { mediática de los } \\
\text { países }\end{array}$ & $\begin{array}{c}\text { Teoría del } \\
\text { enfoque y análisis } \\
\text { de contenido }\end{array}$ & $\begin{array}{c}\text { Periódicos } \\
\text { españoles (El País, } \\
\text { El Mundo, La } \\
\text { Vanguardia, El } \\
\text { Periódico de } \\
\text { Cataluña y ABC) }\end{array}$ & Libia & $\begin{array}{c}\text { Libia, tratamiento } \\
\text { mediático, prensa } \\
\text { española, comunidad } \\
\text { internacional, Derechos } \\
\text { Humanos }\end{array}$ \\
\hline $\begin{array}{l}\text { Las asociaciones } \\
\text { "marca producto" y } \\
\text { "marca ciudad" como } \\
\text { estrategia de "city } \\
\text { branding". Una } \\
\text { aproximación a los } \\
\text { casos de Nueva York, } \\
\text { París y Londres }\end{array}$ & $\begin{array}{l}\text { Efecto "made } \\
\text { in" }\end{array}$ & Estudio de caso & Marcas de ciudad & $\begin{array}{c}\text { Nueva York, } \\
\text { París y } \\
\text { Londres }\end{array}$ & $\begin{array}{c}\text { Marca ciudad, city } \\
\text { marketing, city } \\
\text { branding, cobranding, } \\
\text { alianza de marca, } \\
\text { brandificación, efecto } \\
\text { "made in" }\end{array}$ \\
\hline $\begin{array}{l}\text { Catalan-ness(es) in the } \\
\text { Catalan Countries }\end{array}$ & $\begin{array}{l}\text { Representacione } \\
\text { s de la identidad } \\
\text { nacional }\end{array}$ & $\begin{array}{c}\text { Revisión } \\
\text { bibliográfica / } \\
\text { Ensayo }\end{array}$ & $\begin{array}{c}\text { Discursos, } \\
\text { prácticas, cambios } \\
\text { y continuidades } \\
\text { sobre la idea de } \\
\text { catalanidad }\end{array}$ & $\begin{array}{c}\text { Países } \\
\text { Catalanes } \\
\text { (Cataluña, } \\
\text { Valencia, } \\
\text { Baleares y } \\
\text { Cataluña } \\
\text { Norte - } \\
\text { España y } \\
\text { Francia) }\end{array}$ & $\begin{array}{l}\text { 1960s, globalisation, } \\
\text { identity, Catalan-ness, } \\
\text { Catalan Countries }\end{array}$ \\
\hline
\end{tabular}




\begin{tabular}{|c|c|c|c|c|c|}
\hline $\begin{array}{l}\text { Naciones que se leen: } \\
\text { consumo de prensa e } \\
\text { identidad nacional }\end{array}$ & $\begin{array}{l}\text { Construcción de } \\
\text { identidades } \\
\text { nacionales a } \\
\text { través de los } \\
\text { medios }\end{array}$ & $\begin{array}{l}\text { Observación } \\
\text { participante, } \\
\text { estudios piloto y } \\
\text { entrevistas en } \\
\text { profundidad }\end{array}$ & $\begin{array}{l}\text { Estudiantes de } \\
\text { culturas y países } \\
\text { muy diversos }\end{array}$ & $\begin{array}{l}\text { Mundo en } \\
\text { general }\end{array}$ & No hay \\
\hline $\begin{array}{l}\text { La construcción de la } \\
\text { Unión Europea y la } \\
\text { necesidad de consolidar } \\
\text { una política de } \\
\text { comunicación europea } \\
\text { (o de la influencia de la } \\
\text { voluntad política sobre } \\
\text { el modo de una } \\
\text { comunicación de } \\
\text { decisiones) }\end{array}$ & $\begin{array}{l}\text { Políticas de } \\
\text { comunicación } \\
\text { para la } \\
\text { construcción de } \\
\text { identidades } \\
\text { supranacionales }\end{array}$ & $\begin{array}{l}\text { Revisión } \\
\text { documental }\end{array}$ & $\begin{array}{l}\text { Libro Blanco sobre } \\
\text { una Política de } \\
\text { Comunicación } \\
\text { Europea }\end{array}$ & $\begin{array}{l}\text { Unión } \\
\text { Europea }\end{array}$ & $\begin{array}{c}\text { Construcción europea, } \\
\text { demos europeo, } \\
\text { Política de } \\
\text { Comunicación } \\
\text { Europea, } \\
\text { supranacionalidad, } \\
\text { participación, } \\
\text { transparencia, esfera } \\
\text { pública europea }\end{array}$ \\
\hline $\begin{array}{l}\text { La diplomacia, como } \\
\text { factor de comunicación } \\
\text { del sistema inter-estatal }\end{array}$ & $\begin{array}{l}\text { Historia de la } \\
\text { diplomacia } \\
\text { pública }\end{array}$ & $\begin{array}{c}\text { Revisión } \\
\text { bibliográfica }\end{array}$ & Datos secundarios & $\begin{array}{l}\text { Mundo en } \\
\text { general }\end{array}$ & $\begin{array}{c}\text { Diplomacia, inter- } \\
\text { estatal }\end{array}$ \\
\hline $\begin{array}{l}\text { Para captar alemanes: } \\
\text { La propaganda nazi en } \\
\text { España de la Segunda } \\
\text { República mediante } \\
\text { películas (1933-1936) }\end{array}$ & $\begin{array}{l}\text { Propaganda } \\
\text { nacional en el } \\
\text { cine }\end{array}$ & $\begin{array}{l}\text { Revisión } \\
\text { documental }\end{array}$ & $\begin{array}{c}\text { Correspondencia } \\
\text { entre la Embajada } \\
\text { Alemana en España } \\
\text { y el Ministerio } \\
\text { Alemán de Asuntos } \\
\text { Exteriores (1935- } \\
1945)\end{array}$ & $\begin{array}{l}\text { España y } \\
\text { Alemania }\end{array}$ & $\begin{array}{l}\text { Propaganda, películas } \\
\text { documentales, } \\
\text { proyecciones en salas }\end{array}$ \\
\hline $\begin{array}{l}\text { La diplomacia pública } \\
\text { americana: Lecciones } \\
\text { para una comunicación } \\
\text { internacional }\end{array}$ & $\begin{array}{l}\text { Estrategias de } \\
\text { diplomacia } \\
\text { pública }\end{array}$ & Entrevistas & $\begin{array}{l}\text { Funcionarios del } \\
\text { Departamento de } \\
\text { Estado en } \\
\text { Washington DC }\end{array}$ & $\begin{array}{l}\text { Estados } \\
\text { Unidos de } \\
\text { América }\end{array}$ & $\begin{array}{c}\text { Diplomacia pública, } \\
\text { Soft power-hard power, } \\
\text { Batalla por las mentes y } \\
\text { transformational } \\
\text { diplomacy, Estrategias } \\
\text { de comunicación } \\
\text { política internacional, } \\
\text { Política exterior de } \\
\text { Bush }\end{array}$ \\
\hline $\begin{array}{l}\text { Para estudiar la } \\
\text { comunicación de los } \\
\text { gobiernos: Un análisis } \\
\text { del estado de la } \\
\text { cuestión }\end{array}$ & $\begin{array}{l}\text { Singularidades } \\
\text { de la } \\
\text { comunicación } \\
\text { de los gobiernos } \\
\text { (incluyendo la } \\
\text { diplomacia } \\
\text { pública) }\end{array}$ & $\begin{array}{c}\text { Revisión } \\
\text { bibliográfica }\end{array}$ & Datos secundarios & $\begin{array}{l}\text { Mundo en } \\
\text { general }\end{array}$ & $\begin{array}{l}\text { Comunicación de } \\
\text { gobierno, } \\
\text { comunicación de la } \\
\text { gestión pública }\end{array}$ \\
\hline $\begin{array}{l}\text { Hacia una teoría } \\
\text { comunicativa de la } \\
\text { diplomacia pública }\end{array}$ & $\begin{array}{l}\text { Estrategias de } \\
\text { comunicación } \\
\text { en diplomacia } \\
\text { pública }\end{array}$ & $\begin{array}{c}\text { Revisión } \\
\text { bibliográfica }\end{array}$ & Datos secundarios & $\begin{array}{l}\text { Mundo en } \\
\text { general }\end{array}$ & $\begin{array}{l}\text { Diplomacia pública, } \\
\text { Estrategias de } \\
\text { comunicación, } \\
\text { Relaciones } \\
\text { Internacionales, } \\
\text { Televisión } \\
\text { internacional, Redes } \\
\text { Sociales }\end{array}$ \\
\hline $\begin{array}{l}\text { Communication, } \\
\text { destination brands and } \\
\text { mobile applications }\end{array}$ & $\begin{array}{l}\text { Comunicación } \\
\text { de marcas de } \\
\text { destino } \\
\text { mediante } \\
\text { aplicaciones } \\
\text { móviles }\end{array}$ & $\begin{array}{l}\text { Análisis } \\
\text { comparativo }\end{array}$ & $\begin{array}{l}\text { Aplicaciones } \\
\text { móviles }\end{array}$ & $\begin{array}{c}\text { Andalucía, } \\
\text { Barcelona, } \\
\text { Comunidad } \\
\text { Valenciana, } \\
\text { Madrid, } \\
\text { Santiago de } \\
\text { Compostela, } \\
\text { Tenerife } \\
\text { (España), } \\
\text { Dublín, } \\
\text { Tailandia y } \\
\text { Toronto }\end{array}$ & $\begin{array}{l}\text { Tourist communication, } \\
\text { Destination brand, } \\
\text { Destination branding, } \\
\text { Mobile application, } \\
\text { Place branding, Marca } \\
\text { de destino, } \\
\text { Comunicación turística, } \\
\text { Aplicación móvil }\end{array}$ \\
\hline
\end{tabular}




\begin{tabular}{|c|c|c|c|c|c|}
\hline $\begin{array}{l}\text { Framing as a tool for } \\
\text { mediatic diplomacy } \\
\text { analysis: Study of } \\
\text { George W. Bush's } \\
\text { political discourse in } \\
\text { the "War on Terror" }\end{array}$ & $\begin{array}{l}\text { Diplomacia } \\
\text { mediática como } \\
\text { variante de la } \\
\text { diplomacia } \\
\text { pública }\end{array}$ & $\begin{array}{l}\text { Teoría del framing } \\
\text { en estudio de caso }\end{array}$ & $\begin{array}{c}\text { Discursos de } \\
\text { George W. Bush }\end{array}$ & $\begin{array}{l}\text { Estados } \\
\text { Unidos de } \\
\text { América }\end{array}$ & $\begin{array}{l}\text { Bush, Diplomacia } \\
\text { pública, Nueva } \\
\text { diplomacia pública, } \\
\text { Diplomacia mediática, } \\
\text { Discurso político, } \\
\text { Guerra contra el Terror }\end{array}$ \\
\hline $\begin{array}{l}\text { Framing ideology: How } \\
\text { Time magazine } \\
\text { represents nationalism } \\
\text { and identities through } \\
\text { visual reporting }\end{array}$ & $\begin{array}{l}\text { Ideologías de } \\
\text { identidad en los } \\
\text { medios }\end{array}$ & $\begin{array}{l}\text { Teoría del framing } \\
\text { en estudio de caso }\end{array}$ & $\begin{array}{l}\text { Portadas de la } \\
\text { revista Time }\end{array}$ & $\begin{array}{l}\text { Estados } \\
\text { Unidos de } \\
\text { América }\end{array}$ & $\begin{array}{c}\text { Análisis del encuadre } \\
\text { visual, Guerra de Irak, } \\
\text { Ideologías de identidad, } \\
\text { Nacionalismo, Revista } \\
\text { Time }\end{array}$ \\
\hline $\begin{array}{l}\text { El tractament del } \\
\text { turisme en els diaris } \\
\text { editats a Catalunya }\end{array}$ & $\begin{array}{l}\text { Tratamiento } \\
\text { mediático del } \\
\text { turismo }\end{array}$ & $\begin{array}{l}\text { Análisis del } \\
\text { contenido }\end{array}$ & $\begin{array}{c}\text { Periódicos } \\
\text { españoles (Avui, El } \\
\text { Periódico, El País, } \\
\text { La Vanguardia, El } \\
\text { Diari de } \\
\text { Barcelona, El Punt } \\
\text { de Girona) }\end{array}$ & $\begin{array}{l}\text { Cataluña } \\
\text { (España) }\end{array}$ & No hay \\
\hline $\begin{array}{l}\text { La gestió de les } \\
\text { marques de destinació i } \\
\text { de territori des de la } \\
\text { perspectiva de les } \\
\text { relaciones públiques }\end{array}$ & $\begin{array}{l}\text { Gestión de las } \\
\text { marcas de } \\
\text { destino y de } \\
\text { territorio }\end{array}$ & Encuesta en línea & $\begin{array}{l}\text { Gestores y } \\
\text { profesionales } \\
\text { responsables de } \\
\text { comunicación de } \\
\text { las principales } \\
\text { marcas de destino } \\
\text { españolas }\end{array}$ & España & $\begin{array}{l}\text { Relaciones públicas, } \\
\text { marcas de destino, } \\
\text { marcas de territorio, } \\
\text { marketing, reputación, } \\
\text { turismo }\end{array}$ \\
\hline $\begin{array}{l}\text { Los espejismos de la } \\
\text { intercomunicación } \\
\text { turística }\end{array}$ & $\begin{array}{l}\text { Comunicación } \\
\text { turística e } \\
\text { interculturalidad }\end{array}$ & $\begin{array}{l}\text { Revisión } \\
\text { bibliográfica / } \\
\text { Ensayo }\end{array}$ & Datos secundarios & $\begin{array}{l}\text { Andalucía } \\
\text { (España), } \\
\text { España y } \\
\text { Mundo }\end{array}$ & No hay \\
\hline $\begin{array}{l}\text { Comportamiento } \\
\text { estratégico de la } \\
\text { promoción turística } \\
\text { española }\end{array}$ & $\begin{array}{l}\text { Publicidad } \\
\text { turística de un } \\
\text { país }\end{array}$ & $\begin{array}{l}\text { Revisión } \\
\text { bibliográfica / } \\
\text { Ensayo }\end{array}$ & Datos secundarios & España & $\begin{array}{l}\text { Publicidad, turismo, } \\
\text { marketing estratégico, } \\
\text { imagen }\end{array}$ \\
\hline $\begin{array}{c}\text { Análisis de la } \\
\text { publicidad institucional } \\
\text { del Estado español: } \\
\text { objetivos y cualidades } \\
\text { discursivas }\end{array}$ & $\begin{array}{c}\text { Publicidad } \\
\text { institucional de } \\
\text { un país }\end{array}$ & $\begin{array}{c}\text { Análisis } \\
\text { fundamentado en } \\
\text { la Teoría de la } \\
\text { Enunciación }\end{array}$ & $\begin{array}{l}\text { Anuncios de } \\
\text { televisión (75) }\end{array}$ & España & $\begin{array}{c}\text { Comunicación política, } \\
\text { publicidad, } \\
\text { enunciación, retórica }\end{array}$ \\
\hline $\begin{array}{l}\text { A fundação e os } \\
\text { fundamentos das novas } \\
\text { cidades: entre meios e } \\
\text { medos }\end{array}$ & $\begin{array}{l}\text { Comunicación } \\
\text { de las ciudades }\end{array}$ & $\begin{array}{l}\text { Revisión } \\
\text { bibliográfica / } \\
\text { Ensayo }\end{array}$ & Datos secundarios & Brasil & $\begin{array}{l}\text { Ciudades del siglo } \\
\text { XXI, comunicación e } \\
\text { ciudad, sociedad de la } \\
\text { información }\end{array}$ \\
\hline $\begin{array}{l}\text { El análisis formal de } \\
\text { sitios web y su papel en } \\
\text { la promoción del } e \text { - } \\
\text { turismo }\end{array}$ & $\begin{array}{l}\text { Promoción del } \\
\text { turismo en } \\
\text { internet }\end{array}$ & $\begin{array}{l}\text { Análisis de } \\
\text { contenido }\end{array}$ & $\begin{array}{l}\text { Sitios web de } \\
\text { municipios }\end{array}$ & $\begin{array}{l}\text { Castilla y } \\
\text { León } \\
\text { (España) }\end{array}$ & $\begin{array}{l}\text { Internet, diseño web, } \\
\text { análisis formal, } e- \\
\text { turismo }\end{array}$ \\
\hline $\begin{array}{l}\text { Islam i món àrab a } \\
\text { l'escola i als mitjans }\end{array}$ & $\begin{array}{l}\text { Imágenes de } \\
\text { países y } \\
\text { religiones en la } \\
\text { escuela y en los } \\
\text { medios }\end{array}$ & $\begin{array}{c}\text { Revisión } \\
\text { bibliográfica }\end{array}$ & Datos secundarios & $\begin{array}{l}\text { Mundo árabe } \\
\text { e islámico }\end{array}$ & No hay \\
\hline $\begin{array}{l}\text { Diplomacia, marketing } \\
\text { político y opinión } \\
\text { pública en el viaje de } \\
\text { los reyes a los Estados } \\
\text { Unidos en junio de } \\
1976\end{array}$ & $\begin{array}{l}\text { Diplomacia, } \\
\text { marketing } \\
\text { político y } \\
\text { opinión pública } \\
\text { en los viajes de } \\
\text { jefes de estado }\end{array}$ & $\begin{array}{l}\text { Desconocido - No } \\
\text { ha podido } \\
\text { accederse ni al } \\
\text { resumen ni al } \\
\text { texto completo }\end{array}$ & $\begin{array}{l}\text { Desconocido - No } \\
\text { ha podido } \\
\text { accederse ni al } \\
\text { resumen ni al texto } \\
\text { completo }\end{array}$ & $\begin{array}{l}\text { España y } \\
\text { Estados } \\
\text { Unidos }\end{array}$ & No hay \\
\hline $\begin{array}{l}\text { Nativos y forasteros: } \\
\text { Una aproximación } \\
\text { antropológica al } \\
\text { turismo de masas }\end{array}$ & $\begin{array}{l}\text { Relaciones entre } \\
\text { residentes y } \\
\text { turistas en } \\
\text { turismo de } \\
\text { masas }\end{array}$ & $\begin{array}{l}\text { Desconocido - No } \\
\text { ha podido } \\
\text { accederse ni al } \\
\text { resumen ni al } \\
\text { texto completo }\end{array}$ & $\begin{array}{l}\text { Desconocido - No } \\
\text { ha podido } \\
\text { accederse ni al } \\
\text { resumen ni al texto } \\
\text { completo }\end{array}$ & Desconocido & No hay \\
\hline
\end{tabular}




\begin{tabular}{|c|c|c|c|c|c|}
\hline $\begin{array}{c}\text { Los contenidos } \\
\text { informativos } \\
\text { territoriales en las } \\
\text { cadenas generalistas de } \\
\text { radio: la imagen de } \\
\text { Andalucía en el } \\
\text { contexto informativo } \\
\text { radiofónico español }\end{array}$ & $\begin{array}{l}\text { Imagen de las } \\
\text { regiones en los } \\
\text { medios } \\
\text { nacionales }\end{array}$ & $\begin{array}{l}\text { Análisis de } \\
\text { contenido }\end{array}$ & $\begin{array}{l}\text { Cadenas de radio } \\
\text { españolas de } \\
\text { ámbito nacional } \\
\text { (SER, COPE, } \\
\text { RNE, ONDA } \\
\text { CERO y PUNTO } \\
\text { RADIO) }\end{array}$ & $\begin{array}{l}\text { Andalucía } \\
\text { (España) }\end{array}$ & $\begin{array}{l}\text { Noticia, imagen, } \\
\text { opinión, entrevista e } \\
\text { información }\end{array}$ \\
\hline $\begin{array}{c}\text { La diplomacia del } \\
\text { presente: universo } 2.0 \\
\text { al alcance de la mano }\end{array}$ & $\begin{array}{c}\text { Diplomacia } \\
\text { pública en redes } \\
\text { sociales }\end{array}$ & $\begin{array}{l}\text { Revisión } \\
\text { bibliográfica }\end{array}$ & Datos secundarios & $\begin{array}{l}\text { Mundo en } \\
\text { general }\end{array}$ & $\begin{array}{l}\text { Diplomacia tradicional, } \\
\text { diplomacia multilateral, } \\
\text { diplomacia pública, } \\
\text { diplomacia } 2.0 \text {, redes } \\
\text { sociales, conflicto, } \\
\text { relaciones } \\
\text { internacionales }\end{array}$ \\
\hline $\begin{array}{l}\text { La construcción de } \\
\text { estereotipos andaluces } \\
\text { por los medios }\end{array}$ & $\begin{array}{l}\text { Imagen de las } \\
\text { regiones en los } \\
\text { medios } \\
\text { nacionales }\end{array}$ & Ensayo & Medios nacionales & $\begin{array}{l}\text { Andalucía } \\
\text { (España) }\end{array}$ & No hay \\
\hline $\begin{array}{c}\text { La doble mirada sobre } \\
\text { Andalucía }\end{array}$ & $\begin{array}{l}\text { Imagen de las } \\
\text { regiones en los } \\
\text { medios } \\
\text { nacionales }\end{array}$ & Ensayo & Medios nacionales & $\begin{array}{l}\text { Andalucía } \\
\text { (España) }\end{array}$ & No hay \\
\hline $\begin{array}{c}\text { La ciudad es el medio, } \\
\text { el territorio es el } \\
\text { mensaje }\end{array}$ & $\begin{array}{l}\text { Comunicación } \\
\text { de las ciudades }\end{array}$ & Ensayo & Datos secundarios & $\begin{array}{l}\text { Mundo en } \\
\text { general }\end{array}$ & No hay \\
\hline $\begin{array}{l}\text { La cultura andaluza en } \\
\text { los libros de texto }\end{array}$ & $\begin{array}{l}\text { Imagen de las } \\
\text { regiones en la } \\
\text { educación }\end{array}$ & $\begin{array}{l}\text { Análisis de } \\
\text { contenido }\end{array}$ & Libros de texto & $\begin{array}{l}\text { Andalucía } \\
\text { (España) }\end{array}$ & No hay \\
\hline $\begin{array}{l}\text { Andaluces en la } \\
\text { telerrealidad: la } \\
\text { audiencia a través del } \\
\text { estereotipo del andaluz } \\
\text { anónimo en televisión }\end{array}$ & $\begin{array}{l}\text { Imagen de las } \\
\text { regiones en los } \\
\text { medios } \\
\text { nacionales }\end{array}$ & $\begin{array}{l}\text { Análisis de } \\
\text { contenido }\end{array}$ & $\begin{array}{l}\text { Programas de } \\
\text { telerrealidad } \\
\text { españoles }\end{array}$ & $\begin{array}{l}\text { Andalucía } \\
\text { (España) }\end{array}$ & $\begin{array}{c}\text { Reality show, andaluz, } \\
\text { estereotipo, audiencia, } \\
\text { televisión }\end{array}$ \\
\hline $\begin{array}{l}\text { La marca de destino. El } \\
\text { valor intangible de un } \\
\text { destino y su protección } \\
\text { jurídica }\end{array}$ & $\begin{array}{c}\text { Marcas de } \\
\text { destino desde la } \\
\text { perspectiva } \\
\text { jurídica }\end{array}$ & $\begin{array}{c}\text { Revisión } \\
\text { bibliográfica / } \\
\text { Ensayo }\end{array}$ & Datos secundarios & $\begin{array}{l}\text { Mundo en } \\
\text { general }\end{array}$ & $\begin{array}{c}\text { Marca, marca país, } \\
\text { destino geográfico, } \\
\text { identidad, } \\
\text { posicionamiento, activo } \\
\text { intangible }\end{array}$ \\
\hline $\begin{array}{c}\text { Teoría de la } \\
\text { comunicación y } \\
\text { paisaje. Las geografías } \\
\text { del sujeto y la } \\
\text { perspectiva } \\
\text { interpretativa de la } \\
\text { comunicación }\end{array}$ & $\begin{array}{l}\text { Comunicación } \\
\text { del paisaje }\end{array}$ & $\begin{array}{c}\text { Revisión } \\
\text { bibliográfica / } \\
\text { Ensayo }\end{array}$ & Datos secundarios & $\begin{array}{l}\text { Mundo en } \\
\text { general }\end{array}$ & $\begin{array}{l}\text { Paisaje, comunicación, } \\
\text { identidad, territorio }\end{array}$ \\
\hline $\begin{array}{c}\text { La comunicación } \\
\text { institucional y de } \\
\text { servicios. Las páginas } \\
\text { web municipales de las } \\
\text { capitales de provincia } \\
\text { españolas }\end{array}$ & $\begin{array}{l}\text { Comunicación } \\
\text { de la e- } \\
\text { Administración } \\
\text { local con sus } \\
\text { públicos }\end{array}$ & $\begin{array}{l}\text { Análisis de la } \\
\text { oferta informativa, } \\
\text { la facilidad de uso } \\
\text { y la capacidad de } \\
\text { respuesta del } \\
\text { usuario }\end{array}$ & $\begin{array}{c}\text { Páginas web } \\
\text { municipales de las } \\
52 \text { capitales de } \\
\text { provincia españolas }\end{array}$ & España & $\begin{array}{c}\text { Comunicación } \\
\text { institucional, } \\
\text { administración } \\
\text { electrónica, webs } \\
\text { municipales, nuevas } \\
\text { tecnologías, } \\
\text { ayuntamientos }\end{array}$ \\
\hline $\begin{array}{c}\text { Las redes sociales en } \\
\text { las marcas turísticas de } \\
\text { la Comunidad } \\
\text { Valenciana }\end{array}$ & $\begin{array}{c}\text { Marcas de } \\
\text { destino en redes } \\
\text { sociales }\end{array}$ & $\begin{array}{l}\text { Método } \\
\text { descriptivo con } \\
\text { análisis de } \\
\text { contenido }\end{array}$ & $\begin{array}{l}\text { Páginas web y } \\
\text { redes sociales de } 4 \\
\text { marcas turísticas } \\
\text { valencianas }\end{array}$ & $\begin{array}{c}\text { Comunidad } \\
\text { Valenciana } \\
\text { (España) }\end{array}$ & $\begin{array}{c}\text { Redes sociales, marcas } \\
\text { turísticas, Comunidad } \\
\text { Valenciana }\end{array}$ \\
\hline $\begin{array}{l}\text { La comunicación como } \\
\text { instrumento de la } \\
\text { diplomacia pública }\end{array}$ & $\begin{array}{l}\text { La } \\
\text { comunicación } \\
\text { en diplomacia } \\
\text { pública }\end{array}$ & $\begin{array}{c}\text { Revisión } \\
\text { bibliográfica }\end{array}$ & Datos secundarios & España & $\begin{array}{l}\text { Diplomacia pública, } \\
\text { marca España, } \\
\text { comunicación, } \\
\text { relaciones } \\
\text { internacionales, plan } \\
\text { estratégico de } \\
\text { comunicación integral }\end{array}$ \\
\hline
\end{tabular}




\begin{tabular}{|c|c|c|c|c|c|}
\hline $\begin{array}{l}\text { La construcción de la } \\
\text { marca 'Qatar' a partir } \\
\text { del deporte: 'sports } \\
\text { place branding' y } \\
\text { prensa deportiva } \\
\text { catalana }\end{array}$ & $\begin{array}{l}\text { Atributos de la } \\
\text { construcción de } \\
\text { marca país }\end{array}$ & $\begin{array}{l}\text { Triangulación } \\
\text { metodológica } \\
\text { (Revisión de la } \\
\text { literatura; vaciado } \\
\text { hemerográfico y } \\
\text { entrevistas semi- } \\
\text { estructuradas) }\end{array}$ & $\begin{array}{c}\text { Literatura; } \\
\text { periódicos } \\
\text { deportivos } \\
\text { catalanes (Mundo } \\
\text { Deportivo, Sport y } \\
\text { El } 9 \text { Esportiu) y } \\
\text { especialistas en } \\
\text { periodismo } \\
\text { deportivo }\end{array}$ & Qatar & $\begin{array}{l}\text { FC Barcelona, Qatar, } \\
\text { marca de territorio, } \\
\text { diplomacia pública, } \\
\text { prensa deportiva }\end{array}$ \\
\hline $\begin{array}{c}\text { Medios de } \\
\text { comunicación y marcas } \\
\text { turísticas: la labor de } \\
\text { las oficinas extranjeras } \\
\text { de turismo en España }\end{array}$ & $\begin{array}{l}\text { Acciones de las } \\
\text { oficinas } \\
\text { nacionales de } \\
\text { turismo }\end{array}$ & Entrevistas & $\begin{array}{c}\text { Directivos y } \\
\text { responsables de } \\
\text { comunicación de } \\
\text { oficinas de destinos } \\
\text { turísticos } \\
\text { establecidas en } \\
\text { España }\end{array}$ & $\begin{array}{c}\text { Bélgica, } \\
\text { Suiza, } \\
\text { República } \\
\text { Dominicana, } \\
\text { Suecia }\end{array}$ & $\begin{array}{l}\text { Destination branding, } \\
\text { medios de } \\
\text { comunicación, } \\
\text { periodismo de turismo } \\
\text { y de viajes, publicidad }\end{array}$ \\
\hline $\begin{array}{l}\text { La imagen de la Unión } \\
\text { Europea y de sus países } \\
\text { miembros en la prensa } \\
\text { oficial china Xinhua } \\
\text { online: Un estudio } \\
\text { empírico }\end{array}$ & $\begin{array}{l}\text { Tratamiento y } \\
\text { cobertura } \\
\text { mediática de los } \\
\text { países }\end{array}$ & $\begin{array}{l}\text { Análisis de la } \\
\text { muestra mediante } \\
\text { métodos inductivo } \\
\text { y deductivo }\end{array}$ & $\begin{array}{l}\text { Noticias de la } \\
\text { Prensa Oficial } \\
\text { China Xinhua } \\
\text { Online }\end{array}$ & $\begin{array}{l}\text { Unión } \\
\text { Europea }\end{array}$ & $\begin{array}{l}\text { Agencia informativa, } \\
\text { análisis de contenido, } \\
\text { China, framing, Unión } \\
\text { Europea }\end{array}$ \\
\hline $\begin{array}{c}\text { El estereotipo como } \\
\text { mecanismo de } \\
\text { desintegración de la } \\
\text { identidad nacional. El } \\
\text { caso de Mi gran boda } \\
\text { griega }\end{array}$ & $\begin{array}{c}\text { Estereotipos } \\
\text { nacionales en el } \\
\text { cine }\end{array}$ & $\begin{array}{l}\text { Análisis de } \\
\text { contenido }\end{array}$ & $\begin{array}{l}\text { Mi Gran Bonda } \\
\text { Griega (película) }\end{array}$ & Grecia & $\begin{array}{l}\text { Prototipo, Arquetipo, } \\
\text { Estereotipo, Nación, } \\
\text { Identidad }\end{array}$ \\
\hline $\begin{array}{c}\text { El nacionalismo polaco } \\
\text { a través de la película } \\
\text { Kanal }\end{array}$ & $\begin{array}{l}\text { Representacione } \\
\text { s de la identidad } \\
\text { nacional en el } \\
\text { cine }\end{array}$ & $\begin{array}{l}\text { Análisis de } \\
\text { contenido }\end{array}$ & Kanal (película) & Polonia & No hay \\
\hline $\begin{array}{l}\text { La catalanitat a les } \\
\text { marques de begudes } \\
\text { catalanes }\end{array}$ & $\begin{array}{c}\text { Representacione } \\
\text { s de la identidad } \\
\text { nacional en } \\
\text { productos } \\
\text { comerciales }\end{array}$ & $\begin{array}{l}\text { Análisis de } \\
\text { contenido }\end{array}$ & $\begin{array}{c}\text { Anuncios de TV de } \\
\text { marcas de bebidas } \\
\text { catalanas }\end{array}$ & $\begin{array}{l}\text { Cataluña } \\
\text { (España) }\end{array}$ & $\begin{array}{l}\text { Identidad colectiva; } \\
\text { marketing territorial; } \\
\text { publicidad; } \\
\text { nacionalismo; Cataluña }\end{array}$ \\
\hline $\begin{array}{c}\text { Las relaciones } \\
\text { diplomáticas entre } \\
\text { España y México a } \\
\text { través del cónsul } \\
\text { Agustín de Letamendi } \\
(1839-1842)\end{array}$ & $\begin{array}{l}\text { Diplomacia } \\
\text { internacional a } \\
\text { través de los } \\
\text { consulados }\end{array}$ & $\begin{array}{l}\text { Revisión } \\
\text { bibliográfica / } \\
\text { Ensayo }\end{array}$ & Datos secundarios & $\begin{array}{l}\text { España y } \\
\text { México }\end{array}$ & No hay \\
\hline $\begin{array}{l}\text { 1898: Apuntes sobre la } \\
\text { diplomacia } \\
\text { internacional y la } \\
\text { opinión pública }\end{array}$ & $\begin{array}{c}\text { Diplomacia } \\
\text { internacional y } \\
\text { opinión pública }\end{array}$ & $\begin{array}{c}\text { Revisión } \\
\text { bibliográfica / } \\
\text { Ensayo }\end{array}$ & Datos secundarios & España & No hay \\
\hline $\begin{array}{l}\text { Intervención extranjera } \\
\text { y propaganda. La } \\
\text { propaganda exterior de } \\
\text { las dos Españas }\end{array}$ & $\begin{array}{l}\text { Propaganda } \\
\text { exterior de un } \\
\text { país }\end{array}$ & $\begin{array}{l}\text { Revisión } \\
\text { bibliográfica / } \\
\text { Ensayo }\end{array}$ & Datos secundarios & España & No hay \\
\hline $\begin{array}{c}\text { Las rutas de guerra y } \\
\text { los periodistas } \\
\text { portugueses }\end{array}$ & $\begin{array}{c}\text { Imagen exterior } \\
\text { de un país en los } \\
\text { medios }\end{array}$ & $\begin{array}{l}\text { Análisis del } \\
\text { contenido }\end{array}$ & $\begin{array}{c}\text { Recortes de la } \\
\text { prensa portuguesa } \\
\text { de } 1938\end{array}$ & España & No hay \\
\hline $\begin{array}{l}\text { Propaganda turística y } \\
\text { estatal en España a } \\
\text { través de sellos y } \\
\text { billetes }\end{array}$ & $\begin{array}{l}\text { Imagen turística } \\
\text { de un país en } \\
\text { productos } \\
\text { creados por la } \\
\text { Administración }\end{array}$ & $\begin{array}{c}\text { Revisión } \\
\text { bibliográfica }\end{array}$ & $\begin{array}{l}\text { Sellos y billetes } \\
\text { españoles }\end{array}$ & España & No hay \\
\hline
\end{tabular}




\begin{tabular}{|c|c|c|c|c|c|}
\hline $\begin{array}{c}\text { Proyecto para un } \\
\text { Nuevo Siglo } \\
\text { Americano y la } \\
\text { ideologización de la } \\
\text { Diplomacia } \\
\text { estadounidense }\end{array}$ & $\begin{array}{l}\text { Estrategia de } \\
\text { diplomacia } \\
\text { pública }\end{array}$ & $\begin{array}{c}\text { Revisión } \\
\text { bibliográfica / } \\
\text { Ensayo }\end{array}$ & Datos secundarios & $\begin{array}{l}\text { Estados } \\
\text { Unidos de } \\
\text { América }\end{array}$ & $\begin{array}{c}\text { Laboratorios de ideas, } \\
\text { Política Exterior de } \\
\text { EEUU, } \\
\text { neoconservadores, } \\
\text { propaganda, manejo de } \\
\text { la percepción, discurso } \\
\text { político, Proyecto para } \\
\text { un Nuevo Siglo } \\
\text { Americano (PNSA), } \\
\text { 11-S, 'halcones' }\end{array}$ \\
\hline $\begin{array}{c}\text { Relaciones } \\
\text { internacionales y } \\
\text { estrategias de } \\
\text { comunicación de la } \\
\text { España de Franco ante } \\
\text { la coyuntura de } 1956\end{array}$ & $\begin{array}{l}\text { Estrategias de } \\
\text { comunicación } \\
\text { en las relaciones } \\
\text { internacionales } \\
\text { de un país }\end{array}$ & $\begin{array}{l}\text { Análisis del } \\
\text { contenido }\end{array}$ & $\begin{array}{c}\text { Acciones de } \\
\text { política exterior } \\
\text { realizadas por el } \\
\text { gobierno de Franco } \\
\text { en } 1956\end{array}$ & España & $\begin{array}{c}\text { Historia de las } \\
\text { relaciones } \\
\text { internacionales, crisis } \\
\text { de 1956, estrategias de } \\
\text { comunicación, imagen } \\
\text { positiva, España de } \\
\text { Franco, Guerra Fría }\end{array}$ \\
\hline $\begin{array}{l}\text { Una aproximación a la } \\
\text { imagen cultural de } \\
\text { España a través de sus } \\
\text { tópicos históricos y } \\
\text { literarios más } \\
\text { significativos }\end{array}$ & $\begin{array}{l}\text { Imagen exterior } \\
\text { de un país en los } \\
\text { medios }\end{array}$ & $\begin{array}{l}\text { Análisis del } \\
\text { contenido }\end{array}$ & $\begin{array}{c}\text { Cine español, } \\
\text { literatura nacional } \\
\text { y extranjera, } \\
\text { noticias de } \\
\text { periódicos } \\
\text { extranjeros, } \\
\text { políticas culturales } \\
\text { españolas }\end{array}$ & España & $\begin{array}{l}\text { Imagen cultural, } \\
\text { España, Tópicos } \\
\text { literarios, históricos }\end{array}$ \\
\hline $\begin{array}{l}\text { Deporte e identidad, o } \\
\text { sobre cómo definirnos }\end{array}$ & $\begin{array}{l}\text { Representacione } \\
\text { s de la identidad } \\
\text { nacional en el } \\
\text { deporte }\end{array}$ & $\begin{array}{c}\text { Revisión } \\
\text { bibliográfica / } \\
\text { Ensayo }\end{array}$ & Datos secundarios & $\begin{array}{l}\text { Mundo en } \\
\text { general }\end{array}$ & $\begin{array}{c}\text { Deporte, identidad, } \\
\text { modernidad defensiva, } \\
\text { nación }\end{array}$ \\
\hline $\begin{array}{c}\text { De la propaganda } \\
\text { franquista a la Marca } \\
\text { España: } 70 \text { años de } \\
\text { Radio Exterior de } \\
\text { España }\end{array}$ & $\begin{array}{l}\text { Propaganda } \\
\text { exterior de un } \\
\text { país }\end{array}$ & $\begin{array}{l}\text { Revisión } \\
\text { bibliográfica y } \\
\text { documental }\end{array}$ & $\begin{array}{l}\text { Datos secundarios } \\
\quad \text { (Literatura e } \\
\text { informes de RTVE) }\end{array}$ & España & $\begin{array}{l}\text { Radio Exterior de } \\
\text { España, emisiones } \\
\text { internacionales, radios } \\
\text { internacionales, } \\
\text { propaganda, } \\
\text { radiodifusión exterior, } \\
\text { Marca España }\end{array}$ \\
\hline $\begin{array}{l}\text { Comunicación e } \\
\text { historia al servicio de la } \\
\text { proyección territorial: } \\
\text { la imagen oriental de la } \\
\text { ciudad de Granada }\end{array}$ & $\begin{array}{l}\text { Atributos de la } \\
\text { construcción de } \\
\text { marca ciudad }\end{array}$ & $\begin{array}{l}\text { Análisis del juego } \\
\text { simbólico }\end{array}$ & $\begin{array}{l}\text { Vías de difusión } \\
\text { del principal icono } \\
\text { de la ciudad: la } \\
\text { Alhambra }\end{array}$ & $\begin{array}{l}\text { Granada } \\
\text { (España) }\end{array}$ & $\begin{array}{l}\text { Patrimonio cultural, } \\
\text { citymarketing, } \\
\text { cityplacement, } \\
\text { Alhambra, Granada, } \\
\text { cine y turismo }\end{array}$ \\
\hline $\begin{array}{l}\text { La imagen de la Marca } \\
\text { España en las redes a } \\
\text { través de su campaña "I } \\
\text { need Spain" }\end{array}$ & $\begin{array}{l}\text { Imagen turística } \\
\text { de un país en } \\
\text { productos } \\
\text { creados por la } \\
\text { Administración }\end{array}$ & $\begin{array}{c}\text { Análisis } \\
\text { descriptivo y } \\
\text { crítico }\end{array}$ & $\begin{array}{c}\text { Piezas y soportes } \\
\text { de la campaña "I } \\
\text { need Spain" (spots, } \\
\text { publicidad impresa, } \\
\text { digital y en } \\
\text { RR.SS.) }\end{array}$ & España & $\begin{array}{l}\text { Imagen de marca país, } \\
\text { internacionalización, } \\
\text { gestión de marca, } \\
\text { medios digitales }\end{array}$ \\
\hline $\begin{array}{l}\text { Publicidad y relaciones } \\
\text { públicas en la } \\
\text { promoción turística del } \\
\text { Patronato Costa } \\
\text { Blanca. 2008-2010 }\end{array}$ & $\begin{array}{l}\text { Estrategias de } \\
\text { comunicación } \\
\text { en marcas } \\
\text { turísticas }\end{array}$ & $\begin{array}{l}\text { Análisis del } \\
\text { contenido }\end{array}$ & $\begin{array}{l}\text { Informes, planes de } \\
\text { gestión, edictos en } \\
\text { el BOP, noticias y } \\
\text { datos sobre el } \\
\text { Patronato Costa } \\
\text { Blanca (2008- } \\
2010)\end{array}$ & $\begin{array}{l}\text { Costa Blanca } \\
\text { de Alicante } \\
\text { (España) }\end{array}$ & $\begin{array}{l}\text { Publicidad turística, } \\
\text { relaciones públicas, } \\
\text { Patronato Turismo } \\
\text { Costa Blanca } \\
\text { Comunidad } \\
\text { Valenciana, España }\end{array}$ \\
\hline $\begin{array}{c}\text { De la marca comercial } \\
\text { a la marca de territorio. } \\
\text { Los casos de la DOC } \\
\text { Priorat y DO Montsant }\end{array}$ & $\begin{array}{l}\text { Creación de } \\
\text { marcas de } \\
\text { territorio a partir } \\
\text { de marcas } \\
\text { comerciales }\end{array}$ & $\begin{array}{c}\text { Análisis } \\
\text { documental y } \\
\text { grupo focal de } \\
\text { discusión }\end{array}$ & $\begin{array}{l}\text { Actores de } \\
\text { referencia de la } \\
\text { sociedad de la } \\
\text { comarca (payeses, } \\
\text { enólogos...) }\end{array}$ & $\begin{array}{l}\text { Comarca del } \\
\text { Priorat } \\
\text { (Cataluña, } \\
\text { España) }\end{array}$ & $\begin{array}{l}\text { Marca de territorio, } \\
\text { DOC Priorat, DO } \\
\text { Montsan, desarrollo } \\
\text { local, UNESCO }\end{array}$ \\
\hline $\begin{array}{l}\text { El orgullo patrio como } \\
\text { estrategia comunicativa } \\
\text { en tiempos de crisis }\end{array}$ & $\begin{array}{l}\text { Representacione } \\
\text { s de la identidad } \\
\text { nacional en } \\
\text { anuncios } \\
\text { comerciales }\end{array}$ & Estudio de caso & $\begin{array}{c}\text { Campaña de } \\
\text { comunicación del } \\
\text { Banco Santander }\end{array}$ & España & $\begin{array}{l}\text { Crisis, Publicidad, } \\
\text { España, Banco } \\
\text { Santander }\end{array}$ \\
\hline
\end{tabular}




\begin{tabular}{|c|c|c|c|c|c|}
\hline $\begin{array}{c}\text { Taxonomía de la } \\
\text { diplomacia digital en la } \\
\text { agenda de las nuevas } \\
\text { relaciones } \\
\text { internacionales }\end{array}$ & $\begin{array}{l}\text { La diplomacia } \\
\text { digital en } \\
\text { relaciones } \\
\text { internacionales }\end{array}$ & $\begin{array}{c}\text { Revisión } \\
\text { bibliográfica }\end{array}$ & $\begin{array}{c}\text { Datos secundarios } \\
\text { (Literatura y webs } \\
\text { corporativas) }\end{array}$ & $\begin{array}{l}\text { Estados } \\
\text { Unidos de } \\
\text { América, } \\
\text { Francia, } \\
\text { Suecia y el } \\
\text { Servicio } \\
\text { Europeo de } \\
\text { Acción } \\
\text { Exterior }\end{array}$ & $\begin{array}{c}\text { Diplomacia, } \\
\text { comunicación } \\
\text { internacional, } \\
\text { diplomacia digital, } \\
\text { transparencia }\end{array}$ \\
\hline $\begin{array}{l}\text { La percepción de la } \\
\text { realidad española en el } \\
\text { imaginario colectivo } \\
\text { del inmigrante }\end{array}$ & $\begin{array}{l}\text { Imagen de país } \\
\text { por parte de sus } \\
\text { inmigrantes }\end{array}$ & $\begin{array}{l}\text { Estudio de caso } \\
\text { mediante } \\
\text { entrevistas }\end{array}$ & $\begin{array}{c}\text { Comunidad } \\
\text { argentina, } \\
\text { ecuatoriana, } \\
\text { marroquí, } \\
\text { subsahariana y de } \\
\text { Europa del Este }\end{array}$ & España & $\begin{array}{l}\text { Inmigración, Cultura, } \\
\text { Medios de } \\
\text { Comunicación, } \\
\text { Imaginario, Realidad, } \\
\text { Social, Mitos, } \\
\text { Estereotipos }\end{array}$ \\
\hline $\begin{array}{l}\text { La prensa, la ventana } \\
\text { hacia mundos exóticos. } \\
\text { Imaginarios visuales } \\
\text { pasados y presentes } \\
\text { sobre las otras culturas }\end{array}$ & $\begin{array}{l}\text { Estereotipos } \\
\text { nacionales en el } \\
\text { cómic y en las } \\
\text { fotografías }\end{array}$ & $\begin{array}{l}\text { Análisis de } \\
\text { contenido }\end{array}$ & Prensa española & $\begin{array}{l}\text { Mundo en } \\
\text { general }\end{array}$ & $\begin{array}{l}\text { Representaciones } \\
\text { culturales, Otredad, } \\
\text { Prensa, Imágenes, } \\
\text { Estereotipos }\end{array}$ \\
\hline $\begin{array}{c}\text { internet e identidad } \\
\text { nacional: Estado, } \\
\text { dominios y } \\
\text { comunidades virtuales }\end{array}$ & $\begin{array}{l}\text { Representacione } \\
\text { s de la identidad } \\
\text { nacional en } \\
\text { Internet }\end{array}$ & $\begin{array}{l}\text { Revisión } \\
\text { bibliográfica / } \\
\text { Ensayo }\end{array}$ & Datos secundarios & $\begin{array}{l}\text { Cataluña } \\
\text { (España) }\end{array}$ & $\begin{array}{c}\text { Identidad nacional, } \\
\text { Internet, Dominio, } \\
\text { Comunidades virtuales, } \\
\text { Estado }\end{array}$ \\
\hline $\begin{array}{l}\text { Sobre a identidade } \\
\text { brasileira }\end{array}$ & $\begin{array}{l}\text { Representación } \\
\text { de la identidad } \\
\text { nacional en } \\
\text { contextos } \\
\text { multirraciales }\end{array}$ & Ensayo & Datos secundarios & Brasil & $\begin{array}{l}\text { Identidad, Brasil, la } \\
\text { historia nacional, } \\
\text { creador de las almas }\end{array}$ \\
\hline $\begin{array}{l}\text { El Tercer Mundo } \\
\text { representado: La } \\
\text { imagen como nido de } \\
\text { estereotipos }\end{array}$ & $\begin{array}{l}\text { Representacione } \\
\text { s de la identidad } \\
\text { nacional a través } \\
\text { de las ONG }\end{array}$ & $\begin{array}{l}\text { Análisis de } \\
\text { contenido }\end{array}$ & $\begin{array}{l}\text { Fotografias y } \\
\text { banners de las } \\
\text { páginas de inicio } \\
\text { de } 38 \text { ONGD } \\
\text { españolas }\end{array}$ & $\begin{array}{l}\text { Tercer } \\
\text { Mundo }\end{array}$ & $\begin{array}{l}\text { Tercer Mundo, ONG, } \\
\text { Estereotipo, } \\
\text { Representación gráfica }\end{array}$ \\
\hline $\begin{array}{c}\text { Notoriedad de la } \\
\text { comunicación } \\
\text { institucional a través de } \\
\text { la diplomacia }\end{array}$ & $\begin{array}{l}\text { Técnicas de la } \\
\text { diplomacia } \\
\text { pública, en } \\
\text { especial } 2.0\end{array}$ & $\begin{array}{l}\text { Método de } \\
\text { investigación } \\
\text { descriptivo }\end{array}$ & $\begin{array}{l}\text { Literatura y } \\
\text { estadísticas } \\
\text { publicadas por } \\
\text { terceros }\end{array}$ & $\begin{array}{l}\text { Mundo en } \\
\text { general }\end{array}$ & $\begin{array}{c}\text { Comunicación } \\
\text { institucional, } \\
\text { diplomacia pública, } \\
\text { imagen del Estado }\end{array}$ \\
\hline $\begin{array}{l}\text { El viaje y sus relatos. } \\
\text { Una aproximación a la } \\
\text { construcción de la } \\
\text { imagen de la ciudad } \\
\text { histórica }\end{array}$ & $\begin{array}{l}\text { Evolución de la } \\
\text { imagen de las } \\
\text { ciudades }\end{array}$ & $\begin{array}{l}\text { Visión diacrónica } \\
\text { del relato y } \\
\text { método } \\
\text { iconográfico/ } \\
\text { iconológico }\end{array}$ & $\begin{array}{l}\text { Grabados, } \\
\text { ilustraciones, } \\
\text { pinturas y } \\
\text { fotografías (con o } \\
\text { sin texto) }\end{array}$ & $\begin{array}{l}\text { Ciudad de } \\
\text { Segovia } \\
\text { (España) }\end{array}$ & $\begin{array}{c}\text { Imagen, ciudad, relato, } \\
\text { viaje, Segovia, arte, } \\
\text { arquitectura, paisaje } \\
\text { urbano }\end{array}$ \\
\hline $\begin{array}{l}\text { La marca España desde } \\
\text { la teoría de la } \\
\text { reputación }\end{array}$ & $\begin{array}{c}\text { Estrategia de } \\
\text { marca país }\end{array}$ & $\begin{array}{l}\text { Aplicación de la } \\
\text { teoría de la } \\
\text { reputación }\end{array}$ & $\begin{array}{c}\text { Empresarios, } \\
\text { representantes } \\
\text { políticos y líderes } \\
\text { de opinión de } \\
\text { España, Francia, } \\
\text { Alemania, Italia, } \\
\text { R.U., Rusia, China, } \\
\text { Japón, EUA, } \\
\text { México y Brasil }\end{array}$ & España & No hay \\
\hline $\begin{array}{l}\text { La construcción de la } \\
\text { imagen exterior de } \\
\text { España desde su } \\
\text { política cultural }\end{array}$ & $\begin{array}{c}\text { Políticas } \\
\text { culturales y } \\
\text { construcción de } \\
\text { imagen exterior } \\
\text { de un país }\end{array}$ & $\begin{array}{l}\text { Revisión } \\
\text { bibliográfica y } \\
\text { documental }\end{array}$ & Datos secundarios & España & $\begin{array}{l}\text { Política, imagen, } \\
\text { cultura, España }\end{array}$ \\
\hline $\begin{array}{c}\text { Marketing del } \\
\text { enoturismo en la web } \\
2.0\end{array}$ & $\begin{array}{l}\text { Análisis de las } \\
\text { estrategias de } \\
\text { marketing } 2.0 \\
\text { en enoturismo, } \\
\text { definición del } \\
\text { perfil del turista } \\
\text { interesado en el }\end{array}$ & $\begin{array}{c}\text { Análisis de } \\
\text { contenido de sitio } \\
\text { web y de } \\
\text { cuestionarios } \\
\text { comparativo- } \\
\text { descriptivo }\end{array}$ & Turistas & $\begin{array}{l}\text { La Rioja y } \\
\text { Ribera del } \\
\text { Duero } \\
\text { (España) }\end{array}$ & $\begin{array}{c}\text { Enoturismo, Marketing, } \\
\text { Web 2.0, D.O. Ribera } \\
\text { del Duero, D.O.C. La } \\
\text { Rioja, Comunicación }\end{array}$ \\
\hline
\end{tabular}




\begin{tabular}{|c|c|c|c|c|c|}
\hline $\begin{array}{l}\text { Reposicionamiento de } \\
\text { la imagen turística de }\end{array}$ & $\begin{array}{l}\text { Imagen turística, } \\
\text { Marca de lugar. }\end{array}$ & $\begin{array}{l}\text { Análisis de } \\
\text { contenido }\end{array}$ & Película In Bruges & $\begin{array}{l}\text { Brujas } \\
\text { (Bélgica) }\end{array}$ & No hay \\
\hline $\begin{array}{l}\text { Brujas a través del cine: } \\
\text { de ciudad de cuento a } \\
\text { ciudad de thriller }\end{array}$ & "Movie tourism" & & & & \\
\hline $\begin{array}{l}\text { Marketing para } \\
\text { ciudades: las ciudades } \\
\text { también se venden, las } \\
\text { ciudades también son } \\
\text { productos }\end{array}$ & Marca de ciudad & $\begin{array}{c}\text { Método } \\
\text { cuantitativo } \\
\text { basado en la } \\
\text { escala de Likert }\end{array}$ & Habitantes de Lugo & $\begin{array}{l}\text { Lugo } \\
\text { (España) }\end{array}$ & No hay \\
\hline $\begin{array}{l}\text { La marca territorio } \\
\text { como elemento de la } \\
\text { comunicación: Factor } \\
\text { estratégico del } \\
\text { desarrollo turístico en } \\
\text { Cuenca }\end{array}$ & $\begin{array}{l}\text { Marca de } \\
\text { territorio, } \\
\text { Imagen de } \\
\text { territorio }\end{array}$ & Estudio de caso & Datos secundarios & $\begin{array}{l}\text { Cuenca } \\
\text { (España) }\end{array}$ & $\begin{array}{l}\text { Marca, marca territorio, } \\
\text { imagen de marca, } \\
\text { destino turístico, } \\
\text { sistema global de } \\
\text { identificación }\end{array}$ \\
\hline $\begin{array}{l}\text { Estrategias de «city } \\
\text { placement» } \\
\text { (emplazamiento de } \\
\text { ciudades en el cine) en } \\
\text { la promoción del } \\
\text { turismo español. El } \\
\text { caso de Zindagi Na } \\
\text { Milegi Dobara (Sólo se } \\
\text { vive una vez, 2011) }\end{array}$ & $\begin{array}{l}\text { Posicionamiento } \\
\text { de ciudad }\end{array}$ & $\begin{array}{l}\text { Análisis de } \\
\text { contenido }\end{array}$ & $\begin{array}{l}\text { Película hindú } \\
\text { "Sólo se vive una } \\
\text { vez" }\end{array}$ & $\begin{array}{l}\text { Cataluña, } \\
\text { Valencia, } \\
\text { Andalucía y } \\
\text { Navarra } \\
\text { (España) }\end{array}$ & $\begin{array}{c}\text { Emplazamiento de } \\
\text { ciudades, películas, } \\
\text { ciudades, metodología } \\
\text { de análisis, Sólo se vive } \\
\text { una vez }\end{array}$ \\
\hline $\begin{array}{l}\text { Análisis jurídico de la } \\
\text { publicidad } \\
\text { institucional: estudio de } \\
\text { los bienes propuestos } \\
\text { en la campaña Marca } \\
\text { Perú }\end{array}$ & $\begin{array}{l}\text { Marca de País, } \\
\text { Derecho de la } \\
\text { Comunicación }\end{array}$ & Análisis jurídico & $\begin{array}{c}\text { Campaña } \\
\text { publicitaria Marca } \\
\text { Perú }\end{array}$ & Perú & $\begin{array}{c}\text { Publicidad, comunidad, } \\
\text { comunicación, Marca } \\
\text { Perú, Derecho de la } \\
\text { Comunicación }\end{array}$ \\
\hline $\begin{array}{l}\text { La construcción de la } \\
\text { imagen turística de un } \\
\text { territorio a través de la } \\
\text { publicidad }\end{array}$ & $\begin{array}{l}\text { Imagen y } \\
\text { Destination } \\
\text { Branding }\end{array}$ & $\begin{array}{l}\text { Estudio } \\
\text { descriptivo }\end{array}$ & Datos secundarios & $\begin{array}{l}\text { Castilla y } \\
\text { León } \\
\text { (España) }\end{array}$ & $\begin{array}{l}\text { Publicidad, creatividad } \\
\text { publicitaria, turismo }\end{array}$ \\
\hline $\begin{array}{c}\text { Eficacia de las } \\
\text { campañas publicitarias: } \\
\text { El caso de las } \\
\text { campañas de turismo } \\
\text { del Gobierno Vasco }\end{array}$ & Marca de lugar & $\begin{array}{l}\text { Encuestas y } \\
\text { Análisis } \\
\text { descriptivo }\end{array}$ & $\begin{array}{c}\text { Turistas y } \\
\text { Campañas } \\
\text { turísticas del País } \\
\text { Vasco }\end{array}$ & $\begin{array}{l}\text { País Vasco } \\
\text { (España) }\end{array}$ & $\begin{array}{c}\text { Publicidad, Eficacia } \\
\text { publicitaria, Marketing, } \\
\text { Campaña de Publicidad }\end{array}$ \\
\hline $\begin{array}{l}\text { Cuestiones sobre la } \\
\text { representación } \\
\text { audiovisual de la nueva } \\
\text { Andalucía. } \\
\text { De la amistad al amor: } \\
\text { Campaña } \\
\text { Andalucía te quiere } \\
\text { (2008) }\end{array}$ & $\begin{array}{l}\text { Imagen externa } \\
\text { de una región } \\
\text { proyectada por } \\
\text { la } \\
\text { Administración } \\
\text { Pública. } \\
\text { Destination } \\
\text { Branding }\end{array}$ & $\begin{array}{l}\text { Análisis de } \\
\text { contenido }\end{array}$ & $\begin{array}{l}\text { Campaña turística } \\
\text { de la Junta de } \\
\text { Andalucía de } 2008 \\
\text { (spots, publicidad } \\
\text { gráfica y } \\
\text { radiofónica) }\end{array}$ & $\begin{array}{l}\text { Andalucía } \\
\text { (España) }\end{array}$ & $\begin{array}{l}\text { Andalucía, publicidad, } \\
\text { campaña institucional, } \\
\text { representación } \\
\text { audiovisual }\end{array}$ \\
\hline $\begin{array}{l}\text { Hacia la globalización } \\
\text { del tópico andaluz: } \\
\text { Andalucía te quiere }\end{array}$ & $\begin{array}{c}\text { Análisis } \\
\text { semántico de } \\
\text { una campaña } \\
\text { turística } \\
\text { tomando como } \\
\text { base el } \\
\text { Marketing de } \\
\text { Experiencia }\end{array}$ & $\begin{array}{l}\text { Análisis de } \\
\text { contenido }\end{array}$ & $\begin{array}{c}\text { Campaña turística } \\
\text { "Andalucía te } \\
\text { quiere" }\end{array}$ & $\begin{array}{l}\text { Andalucía } \\
\text { (España) }\end{array}$ & $\begin{array}{l}\text { Tópicos, publicidad } \\
\text { turística, isotopías, } \\
\text { contextos digitales, } \\
\text { publicidad } \\
\text { experiencia }\end{array}$ \\
\hline
\end{tabular}




\begin{tabular}{|c|c|c|c|c|c|}
\hline $\begin{array}{c}\text { La web como } \\
\text { herramienta de } \\
\text { comunicación y } \\
\text { distribución de destinos } \\
\text { turísticos. Análisis y } \\
\text { modelos. }\end{array}$ & $\begin{array}{l}\text { La web como } \\
\text { principal } \\
\text { herramienta de } \\
\text { búsqueda para } \\
\text { turistas }\end{array}$ & $\begin{array}{l}\text { Análisis de } \\
\text { información }\end{array}$ & $\begin{array}{c}\text { Sitios web de } \\
\text { destinos turísticos } \\
\text { la totalidad de las } \\
\text { webs de las } \\
\text { Comunidades } \\
\text { Autónomas (17), } \\
\text { de las capitales de } \\
\text { provincia y de las } \\
\text { Ciudades } \\
\text { Autónomas (52), y } \\
\text { de las webs de las } \\
\text { provincias } \\
\text { pertenecientes a } \\
\text { CCAA no uni- } \\
\text { provinciales (42) }\end{array}$ & $\begin{array}{l}\text { España } \\
\text { (concretamen } \\
\text { te: CCAA, } \\
\text { provincias y } \\
\text { capitales de } \\
\text { provincia) }\end{array}$ & $\begin{array}{c}\text { Comunicación, } \\
\text { Distribución, } \\
\text { Publicidad, Turismo, } \\
\text { Web }\end{array}$ \\
\hline $\begin{array}{l}\text { Social Media en el } \\
\text { sector del enoturismo }\end{array}$ & $\begin{array}{l}\text { Utilizar las } \\
\text { redes sociales } \\
\text { como } \\
\text { plataforma de } \\
\text { promoción } \\
\text { turística para } \\
\text { alcanzar } \\
\text { públicos } \\
\text { extranjeros }\end{array}$ & $\begin{array}{l}\text { Entrevistas en } \\
\text { profundidad y } \\
\text { análisis de } \\
\text { contenido }\end{array}$ & $\begin{array}{l}\text { Profesionales del } \\
\text { enoturismo }\end{array}$ & $\begin{array}{l}\text { Castilla y } \\
\text { León } \\
\text { (España) }\end{array}$ & $\begin{array}{c}\text { Enoturismo, Redes } \\
\text { Sociales, Estrategia de } \\
\text { Comunicación, Vino, } \\
\text { Internet }\end{array}$ \\
\hline $\begin{array}{l}\text { Micro-cluster y nuevo } \\
\text { turista }\end{array}$ & $\begin{array}{l}\text { Promoción del } \\
\text { ecoturismo } \\
\text { como un } \\
\text { turismo de } \\
\text { experiencia. }\end{array}$ & $\begin{array}{c}\text { Revisión } \\
\text { bibliográfica }\end{array}$ & Datos secundarios & $\begin{array}{l}\text { Mundo en } \\
\text { general y } \\
\text { reserva } \\
\text { indígena de } \\
\text { los Malekus } \\
\text { (Costa Rica) } \\
\text { en particular }\end{array}$ & $\begin{array}{l}\text { Desarrollo sostenible, } \\
\text { Sostenibilidad } \\
\text { económica, Turismo }\end{array}$ \\
\hline $\begin{array}{c}\text { Clusters y redes } \\
\text { empresariales en el } \\
\text { contexto del turismo } \\
\text { rural: la experiencia } \\
\text { griega }\end{array}$ & $\begin{array}{l}\text { Promocionar } \\
\text { clusters } \\
\text { turísticos }\end{array}$ & Estudio de caso & Datos secundarios & Grecia & $\begin{array}{l}\text { Clusters, Redes, } \\
\text { Turismo rural, Grecia, } \\
\text { Estudio de caso }\end{array}$ \\
\hline $\begin{array}{l}\text { Dinámica de } \\
\text { competencias y } \\
\text { creación de un clusters } \\
\text { de turismo sostenible: } \\
\text { el caso de cinco tierras }\end{array}$ & $\begin{array}{c}\text { Políticas } \\
\text { Públicas para } \\
\text { apoyar la } \\
\text { generación de } \\
\text { clusters } \\
\text { turísticos }\end{array}$ & $\begin{array}{l}\text { Estudio de caso y } \\
\text { etnológico }\end{array}$ & Locales & $\begin{array}{l}\text { Parque } \\
\text { Nacional de } \\
\text { las Cinco } \\
\text { Tierras } \\
\text { (Italia) }\end{array}$ & $\begin{array}{l}\text { Clusters, Redes, } \\
\text { Turismo rural, Grecia, } \\
\text { Estudio de caso }\end{array}$ \\
\hline $\begin{array}{l}\text { Relaciones Públicas } \\
\text { 2.0. El uso de los } \\
\text { medios sociales en la } \\
\text { estrategia de } \\
\text { comunicación online de } \\
\text { marcas ciudad }\end{array}$ & $\begin{array}{l}\text { Utilizar la web } \\
\text { para la } \\
\text { promoción de } \\
\text { destinos } \\
\text { turísticos en } \\
\text { mercados } \\
\text { internacionales }\end{array}$ & $\begin{array}{l}\text { Análisis de } \\
\text { contenido }\end{array}$ & $\begin{array}{l}\text { Páginas web y } \\
\text { redes sociales de } \\
\text { las diez ciudades } \\
\text { españolas con } \\
\text { mayor población }\end{array}$ & $\begin{array}{l}\text { Madrid, } \\
\text { Barcelona, } \\
\text { Valencia, } \\
\text { Sevilla, } \\
\text { Zaragoza, } \\
\text { Málaga, } \\
\text { Murcia, } \\
\text { Palma de } \\
\text { Mallorca, } \\
\text { Las Palmas } \\
\text { de Gran } \\
\text { Canaria y } \\
\text { Bilbao } \\
\text { (España) }\end{array}$ & $\begin{array}{l}\text { Relaciones Públicas, } \\
\text { Web } 2.0 \text {, marca ciudad, } \\
\text { imagen de marca } \\
\text { ciudad medios sociales }\end{array}$ \\
\hline $\begin{array}{c}\text { La información } \\
\text { publicada en la prensa } \\
\text { internacional como } \\
\text { elemento configurador } \\
\text { de la imagen de los } \\
\text { países }\end{array}$ & $\begin{array}{l}\text { Análisis de la } \\
\text { imagen } \\
\text { proyectada de } \\
\text { un país en } \\
\text { medios de } \\
\text { comunicación } \\
\text { internacionales }\end{array}$ & $\begin{array}{l}\text { Análisis de } \\
\text { contenido }\end{array}$ & $\begin{array}{c}\text { Medios de } \\
\text { Comunicación } \\
\text { online más } \\
\text { importantes de } \\
\text { América Latina y } \\
\text { Europa }\end{array}$ & Paraguay & $\begin{array}{c}\text { Imagen país, gestión de } \\
\text { la imagen, } \\
\text { comunicación de } \\
\text { masas, medios de } \\
\text { comunicación, } \\
\text { Relaciones Públicas }\end{array}$ \\
\hline
\end{tabular}




\begin{tabular}{|c|c|c|c|c|c|}
\hline $\begin{array}{l}\text { Nuevos desafíos en } \\
\text { relaciones públicas 2.0. } \\
\text { La creciente influencia } \\
\text { de las plataformas de } \\
\text { online review en } \\
\text { turismo }\end{array}$ & $\begin{array}{l}\text { Percepciones de } \\
\text { la imagen } \\
\text { turística a través } \\
\text { del Word of } \\
\text { Mouse "De } \\
\text { click en click" }\end{array}$ & Encuestas & $\begin{array}{c}\text { Turistas } \\
\text { portugueses }\end{array}$ & $\begin{array}{l}\text { Destinos } \\
\text { turísticos en } \\
\text { general, } \\
\text { valorados en } \\
\text { Tripadvisor, } \\
\text { Facebook y } \\
\text { Twitter }\end{array}$ & $\begin{array}{l}\text { Comunicación turística, } \\
\text { comunicación } 2.0, \\
\text { relaciones públicas } 2.0, \\
\text { redes sociales, } \\
\text { TripAdvisor }\end{array}$ \\
\hline $\begin{array}{l}\text { Estrategia de medios y } \\
\text { place branding en la } \\
\text { región transnacional } \\
\text { europea de Öresund }\end{array}$ & $\begin{array}{l}\text { Aplicación de } \\
\text { estrategias de } \\
\text { relaciones } \\
\text { públicas a la } \\
\text { promoción de } \\
\text { marca de } \\
\text { destino }\end{array}$ & $\begin{array}{l}\text { Análisis de } \\
\text { contenido }\end{array}$ & $\begin{array}{l}\text { Noticias de prensa } \\
\text { publicadas en la } \\
\text { región de Öresund } \\
\text { entre } 2002 \text { y } 2012\end{array}$ & $\begin{array}{c}\text { Región } \\
\text { transnacional } \\
\text { de Öresund } \\
\text { (Dinamarca } \\
\text { y Suecia) }\end{array}$ & $\begin{array}{l}\text { Estrategia de medios, } \\
\text { región de Öresund, } \\
\text { Place Branding, } \\
\text { relaciones con los } \\
\text { medios }\end{array}$ \\
\hline $\begin{array}{l}\text { El comienzo del } \\
\text { turismo español. Una } \\
\text { aproximación a los } \\
\text { precedentes de las } \\
\text { relaciones públicas } \\
\text { institucionales (1900- } \\
\text { 1950) }\end{array}$ & $\begin{array}{l}\text { Estudio de caso } \\
\text { de la historia de } \\
\text { las relaciones } \\
\text { públicas en } \\
\text { España a } \\
\text { principios del S } \\
\text { XX y su } \\
\text { estrecha } \\
\text { relación con la } \\
\text { promoción de } \\
\text { España como } \\
\text { destino turístico }\end{array}$ & $\begin{array}{c}\text { Revisión } \\
\text { bibliográfica }\end{array}$ & Datos secundarios & España & No hay \\
\hline $\begin{array}{c}\text { Promoción turística a } \\
\text { través del sector } \\
\text { audiovisual. El caso de } \\
\text { Canarias }\end{array}$ & $\begin{array}{l}\text { Promoción } \\
\text { turística, imagen } \\
\text { de destino }\end{array}$ & Ensayo & Datos secundarios & $\begin{array}{c}\text { Islas } \\
\text { Canarias } \\
\text { (España) }\end{array}$ & No hay \\
\hline $\begin{array}{c}\text { Una promoción } \\
\text { turística y un gabinete } \\
\text { de comunicación que } \\
\text { falla }\end{array}$ & $\begin{array}{l}\text { Percepción de la } \\
\text { imagen de } \\
\text { marca }\end{array}$ & $\begin{array}{l}\text { Análisis de } \\
\text { contenido }\end{array}$ & $\begin{array}{l}\text { Periódicos y } \\
\text { campaña } \\
\text { promocional } \\
\text { turística }\end{array}$ & $\begin{array}{c}\text { Islas } \\
\text { Canarias } \\
\text { (España) }\end{array}$ & No hay \\
\hline $\begin{array}{l}\text { Hacia un producto } \\
\text { integral: campaña } \\
\text { promocional de } \\
\text { Canarias durante los } \\
\text { JJ.OO. de } 1996\end{array}$ & $\begin{array}{c}\text { Marca de } \\
\text { destino }\end{array}$ & $\begin{array}{l}\text { Análisis de } \\
\text { contenido }\end{array}$ & $\begin{array}{c}\text { Campaña turística } \\
\text { de Islas Canarias } \\
\text { durante los JJ.OO. } \\
\text { de Atlanta } 1996\end{array}$ & $\begin{array}{c}\text { Islas } \\
\text { Canarias } \\
\text { (España) }\end{array}$ & No hay \\
\hline $\begin{array}{l}\text { La estrategia creativa } \\
\text { en la publicidad } \\
\text { turística. El caso de } \\
\text { Castilla y León. }\end{array}$ & Marca de lugar & $\begin{array}{l}\text { Análisis de } \\
\text { contenido }\end{array}$ & Datos secundarios & $\begin{array}{l}\text { Castilla y } \\
\text { León } \\
\text { (España) }\end{array}$ & $\begin{array}{c}\text { Creatividad } \\
\text { publicitaria, estrategia } \\
\text { creativa publicitaria, } \\
\text { publicidad, campaña } \\
\text { publicitaria, publicidad } \\
\text { audiovisual, spot, } \\
\text { publicidad radiofónica, } \\
\text { cuña, publicidad } \\
\text { gráfica, publicidad } \\
\text { exterior, turismo, } \\
\text { marketing turístico, } \\
\text { imagen turística de un } \\
\text { territorio, Castilla y } \\
\text { León }\end{array}$ \\
\hline $\begin{array}{c}\text { Características y } \\
\text { funciones para marcas } \\
\text { de lugar a partir de un } \\
\text { método Delphi }\end{array}$ & $\begin{array}{l}\text { Evaluación de la } \\
\text { calidad de los } \\
\text { sitios web como } \\
\text { plataformas de } \\
\text { promoción } \\
\text { turística digital }\end{array}$ & Método Delphi & $\begin{array}{c}\text { Expertos en marca } \\
\text { de territorio }\end{array}$ & $\begin{array}{l}\text { Mundo en } \\
\text { general }\end{array}$ & $\begin{array}{l}\text { Marca de lugar, } \\
\text { 'branding', } \\
\text { comunicación, } \\
\text { identidad territorial, } \\
\text { marketing, Delphi }\end{array}$ \\
\hline
\end{tabular}




\begin{tabular}{|c|c|c|c|c|c|}
\hline $\begin{array}{l}\text { Marcas de destino y } \\
\text { evaluación de sitios } \\
\text { web: una metodología } \\
\text { de investigación }\end{array}$ & $\begin{array}{l}\text { Cine como } \\
\text { herramienta de } \\
\text { promoción de } \\
\text { destinos } \\
\text { turísticos }\end{array}$ & $\begin{array}{l}\text { Estudio del } \\
\text { emisor, del } \\
\text { mensaje y del } \\
\text { receptor. Incluye } \\
\text { cuestionarios } \\
\text { dirigidos, encuesta } \\
\text { sociológica, } \\
\text { prueba } \\
\text { experimental de } \\
\text { modificación de } \\
\text { webs, análisis de } \\
\text { webs y posiciona- } \\
\text { miento en } \\
\text { buscadores }\end{array}$ & $\begin{array}{l}\text { Gestores } \\
\text { responsables de } \\
\text { comunicación de } \\
\text { CCAA, ciudades y } \\
\text { regiones españolas; } \\
\text { sitios web; turistas }\end{array}$ & España & $\begin{array}{l}\text { Marca de destino, } \\
\text { turismo, sitio web, } \\
\text { publicidad, place } \\
\text { branding }\end{array}$ \\
\hline $\begin{array}{c}\text { La televisión y la } \\
\text { creación de una nueva } \\
\text { identidad española en } \\
\text { la Transición } \\
\text { (1976-1979) }\end{array}$ & $\begin{array}{l}\text { Construcción de } \\
\text { la identidad } \\
\text { nacional a través } \\
\text { de la televisión }\end{array}$ & $\begin{array}{l}\text { Análisis de } \\
\text { contenido }\end{array}$ & $\begin{array}{l}\text { Televisión } \\
\text { española }\end{array}$ & España & No hay \\
\hline $\begin{array}{l}\text { Percepción Interna y } \\
\text { Externa de la Imagen } \\
\text { de la Marca de España: } \\
\text { Análisis de Métodos de } \\
\text { Evaluación }\end{array}$ & $\begin{array}{l}\text { Marca de país, } \\
\text { Percepción de } \\
\text { imagen interna y } \\
\text { externa }\end{array}$ & $\begin{array}{l}\text { Análisis de datos } \\
\text { cualitativos } \\
\text { secundarios y } \\
\text { análisis de } \\
\text { contenido de datos } \\
\text { secundarios }\end{array}$ & Datos secundarios & España & $\begin{array}{l}\text { Imagen de marca país, } \\
\text { gestión de marca, } \\
\text { imagen corporativa, } \\
\text { comunicación } \\
\text { internacional }\end{array}$ \\
\hline $\begin{array}{c}\text { Uso y Utilidades De } \\
\text { Las Herramientas De } \\
\text { Análisis Online Para La } \\
\text { Evaluación De La } \\
\text { Comunicación De Las } \\
\text { Marcas De Destino A } \\
\text { Través De Los Social } \\
\text { Media }\end{array}$ & $\begin{array}{l}\text { Metodología de } \\
\text { análisis de los } \\
\text { social media y } \\
\text { marca de } \\
\text { destino }\end{array}$ & $\begin{array}{c}\text { Análisis del } \\
\text { contenido, la } \\
\text { interactividad, la } \\
\text { visibilidad, el } \\
\text { éxito y el perfil de } \\
\text { públicos o } \\
\text { usuarios }\end{array}$ & $\begin{array}{c}\text { Facebook y Twitter } \\
\text { de los destinos con } \\
\text { link en la web } \\
\text { oficial }\end{array}$ & $\begin{array}{c}\text { Santiago de } \\
\text { Compostela, } \\
\text { Barcelona, } \\
\text { Sevilla, } \\
\text { Madrid y Las } \\
\text { Palmas de } \\
\text { Gran Canaria } \\
\text { (España) }\end{array}$ & $\begin{array}{l}\text { Relaciones públicas, } \\
\text { social media, } \\
\text { evaluación, análisis } \\
\text { online, marcas de } \\
\text { destino }\end{array}$ \\
\hline $\begin{array}{l}\text { Los MOOC como } \\
\text { herramientas de } \\
\text { diplomacia pública }\end{array}$ & $\begin{array}{l}\text { Diplomacia } \\
\text { pública, } \\
\text { interculturalidad, } \\
\text { Universidades }\end{array}$ & $\begin{array}{c}\text { Revisión } \\
\text { bibliográfica }\end{array}$ & Datos secundarios & $\begin{array}{l}\text { Mundo en } \\
\text { general }\end{array}$ & $\begin{array}{l}\text { Universidad, } \\
\text { Diplomacia pública, } \\
\text { MOOC }\end{array}$ \\
\hline $\begin{array}{c}\text { El podcast como guía } \\
\text { turística }\end{array}$ & $\begin{array}{l}\text { Experience } \\
\text { marketing en } \\
\text { turismo }\end{array}$ & Ensayo & Datos secundarios & $\begin{array}{l}\text { Mundo en } \\
\text { general }\end{array}$ & $\begin{array}{l}\text { Podcast, Sonido, } \\
\text { Turismo 2.0, Ciudad, } \\
\text { Museo, Flâneur }\end{array}$ \\
\hline $\begin{array}{l}\text { Identidad europea y } \\
\text { cambios en la } \\
\text { comunicación. De la } \\
\text { política a la cultura y } \\
\text { los medios }\end{array}$ & $\begin{array}{l}\text { Identidad } \\
\text { nacional, } \\
\text { Comunicación, } \\
\text { Country } \\
\text { Branding }\end{array}$ & Ensayo & Datos secundarios & Europa & \\
\hline $\begin{array}{l}\text { Los Juegos de la } \\
\text { comunicación. }\end{array}$ & $\begin{array}{l}\text { Inicios de marca } \\
\text { de destino }\end{array}$ & Ensayo & Datos secundarios & $\begin{array}{c}\text { Barcelona } \\
\text { (España) }\end{array}$ & $\begin{array}{l}\text { Cataluña, Deporte, } \\
\text { Medios de } \\
\text { comunicación, } \\
\text { Barcelona '92 }\end{array}$ \\
\hline $\begin{array}{l}\text { The image of a city } \\
\text { through the film } \\
\text { industry: Ourense in } \\
\text { Los Girasoles Ciegos }\end{array}$ & Imagen turística & $\begin{array}{l}\text { Análisis del } \\
\text { contenido } \\
\text { (Observation } \\
\text { Documentary } \\
\text { Technique) }\end{array}$ & $\begin{array}{l}\text { Película Los } \\
\text { Girasoles Ciegos }\end{array}$ & $\begin{array}{l}\text { Ourense } \\
\text { (España) }\end{array}$ & $\begin{array}{c}\text { Film, Turismo, } \\
\text { promoción } \\
\text { turística, } \\
\text { Los Girasoles Ciegos }\end{array}$ \\
\hline $\begin{array}{l}\text { Del Spain is different al } \\
\text { Party's over: La } \\
\text { imagen de España a } \\
\text { través de The } \\
\text { Economist (2008- } \\
\text { 2009). }\end{array}$ & $\begin{array}{l}\text { Image } \\
\text { Branding, } \\
\text { Country } \\
\text { Branding, } \\
\text { Medios } \\
\text { impresos }\end{array}$ & $\begin{array}{l}\text { Análisis basado en } \\
\text { una metodología } \\
\text { inductiva }\end{array}$ & $\begin{array}{l}\text { Revista: El } \\
\text { Economista }\end{array}$ & España & $\begin{array}{l}\text { Imagen, estereotipos, } \\
\text { The Economist }\end{array}$ \\
\hline $\begin{array}{l}\text { Advocate of Grassroots } \\
\text { Public Diplomacy }\end{array}$ & $\begin{array}{l}\text { Características } \\
\text { de la diplomacia } \\
\text { pública }\end{array}$ & Ensayo & Datos secundarios & $\begin{array}{l}\text { Estados } \\
\text { Unidos de } \\
\text { América }\end{array}$ & $\begin{array}{c}\text { Diplomacia Pública, } \\
\text { Campañas Políticas, } \\
\text { Liderazgo, } \\
\text { Comunicación }\end{array}$ \\
\hline Public Diplomacy and & Diplomacia & Análisis de & Datos secundarios & Chile & Diplomacia Pública, \\
\hline
\end{tabular}




\begin{tabular}{|c|c|c|c|c|c|}
\hline $\begin{array}{l}\text { Qualitative Jump: The } \\
\text { Case of Chile }\end{array}$ & $\begin{array}{c}\text { pública, Imagen } \\
\text { de País }\end{array}$ & contenido & & & $\begin{array}{l}\text { Chile, Imagen País, } \\
\text { Política Exterior, Plan } \\
\text { estratégico-Chile }\end{array}$ \\
\hline $\begin{array}{l}\text { Relaciones públicas y } \\
\text { nacionalismo: una } \\
\text { aproximación a la } \\
\text { construcción nacional } \\
\text { desde la perspectiva de } \\
\text { las relaciones públicas }\end{array}$ & $\begin{array}{l}\text { Relaciones } \\
\text { públicas, } \\
\text { Country Image } \\
\text { Branding }\end{array}$ & Ensayo & Datos secundarios & $\begin{array}{c}\text { Mundo en } \\
\text { general }\end{array}$ & $\begin{array}{l}\text { Relaciones públicas, el } \\
\text { nacionalismo, la } \\
\text { construcción de la } \\
\text { nación, la identidad } \\
\text { nacional }\end{array}$ \\
\hline $\begin{array}{l}\text { Textual Patterns for PR } \\
\text { on City Marketing } \\
\text { when Dealing with A } \\
\text { German and Italian } \\
\text { Speaking Area }\end{array}$ & $\begin{array}{l}\text { City Branding, } \\
\text { Mensajes }\end{array}$ & $\begin{array}{l}\text { Análisis de } \\
\text { contenido }\end{array}$ & $\begin{array}{l}\text { Sitios web y } \\
\text { folletos }\end{array}$ & $\begin{array}{c}\text { Mundo en } \\
\text { general }\end{array}$ & $\begin{array}{c}\text { Ciudad y marketing de } \\
\text { eventos, La } \\
\text { comunicación } \\
\text { coordinada, los } \\
\text { factores clave de la } \\
\text { imagen que } \\
\text { mutuamente se han } \\
\text { transferido, Pruebas } \\
\text { de Cohesión, } \\
\text { Pruebas, Patrones, } \\
\text { rasgos lingüísticos }\end{array}$ \\
\hline $\begin{array}{c}\text { Gestión de las redes } \\
\text { sociales turísticas en la } \\
\text { web } 2.0\end{array}$ & $\begin{array}{c}\text { Marca de } \\
\text { destino, e-marca } \\
\text { de destino, redes } \\
\text { sociales } \\
\text { turísticas }\end{array}$ & $\begin{array}{l}\text { Análisis de } \\
\text { contenido }\end{array}$ & $\begin{array}{c}\text { Principales redes } \\
\text { sociales de turismo }\end{array}$ & $\begin{array}{c}\text { Mundo en } \\
\text { general }\end{array}$ & $\begin{array}{c}\text { Redes sociales, } \\
\text { Turismo, Web 2., } \\
\text { Comunicación, } \\
\text { Estrategia de } \\
\text { Comercialización, } \\
\text { Internet, E-commerce }\end{array}$ \\
\hline $\begin{array}{c}\text { Consumo del } \\
\text { enoturismo en la D.O. } \\
\text { Ribera del Duero }\end{array}$ & $\begin{array}{l}\text { Características } \\
\text { del enoturista }\end{array}$ & $\begin{array}{l}\text { Cuestionario con } \\
\text { preguntas cerradas }\end{array}$ & Turistas & $\begin{array}{l}\text { Ribera del } \\
\text { Duero } \\
\text { (España) }\end{array}$ & $\begin{array}{l}\text { Enoturismo, D.O. } \\
\text { Ribera del Duero, } \\
\text { Consumo, Coste, } \\
\text { Servicios, Turistas }\end{array}$ \\
\hline $\begin{array}{l}\text { Los festivales de cine } \\
\text { como elemento } \\
\text { potenciador de destinos } \\
\text { turísticos. El caso de } \\
\text { San Sebastián }\end{array}$ & $\begin{array}{l}\text { Turismo cultural } \\
\text { y marca de } \\
\text { destino. }\end{array}$ & $\begin{array}{l}\text { Análisis de } \\
\text { contenido } \\
\text { (comparativo) }\end{array}$ & $\begin{array}{l}\text { Sitios web (fuentes } \\
\text { bibliográficas } \\
\text { secundarias) }\end{array}$ & $\begin{array}{l}\text { Festival de } \\
\text { Cine de San } \\
\text { Sebastián } \\
\text { (España) }\end{array}$ & $\begin{array}{c}\text { Turismo cultural, } \\
\text { Festival de cine, } \\
\text { Destino turístico, } \\
\text { Imagen del destino, San } \\
\text { Sebastián }\end{array}$ \\
\hline $\begin{array}{c}\text { Valladolid como } \\
\text { destino enoturístico }\end{array}$ & $\begin{array}{l}\text { Marca de } \\
\text { destino }\end{array}$ & $\begin{array}{l}\text { Entrevistas en } \\
\text { profundidad, } \\
\text { análisis de } \\
\text { contenido e } \\
\text { interpretación de } \\
\text { resultados }\end{array}$ & $\begin{array}{c}\text { Profesionales del } \\
\text { sector enoturístico }\end{array}$ & $\begin{array}{l}\text { Valladolid } \\
\text { (España) }\end{array}$ & $\begin{array}{l}\text { Valladolid, Vino, } \\
\text { Enoturismo, Marketing, } \\
\text { Comunicación, Evento }\end{array}$ \\
\hline $\begin{array}{c}\text { Comparativa de } \\
\text { contenidos } \\
\text { enoturísticos en la web } \\
2.0\end{array}$ & $\begin{array}{c}\text { Impacto del } \\
\text { internet en el } \\
\text { enoturismo }\end{array}$ & $\begin{array}{l}\text { Análisis } \\
\text { comparativo y } \\
\text { descriptivo }\end{array}$ & $\begin{array}{l}\text { Sitios web } \\
\text { enoturísticos }\end{array}$ & $\begin{array}{l}\text { La Rioja y } \\
\text { Ribera de } \\
\text { Duero } \\
\text { (España) }\end{array}$ & $\begin{array}{c}\text { Enoturismo, Internet, } \\
\text { D.O. Ribera del Duero, } \\
\text { D.O.C. La Rioja, } \\
\text { Marketing }\end{array}$ \\
\hline $\begin{array}{l}\text { El laberíntico caso del } \\
\text { Fauno. A propósito de } \\
\text { la identidad nacional de } \\
\text { las películas }\end{array}$ & $\begin{array}{c}\text { Identidad } \\
\text { nacional a través } \\
\text { del cine }\end{array}$ & $\begin{array}{l}\text { Análisis de } \\
\text { contenido }\end{array}$ & Película & España & $\begin{array}{c}\text { Cine, Cultura, } \\
\text { Identidad, Infancia, } \\
\text { Mito }\end{array}$ \\
\hline $\begin{array}{l}\text { Las ferias profesionales } \\
\text { en Galicia: eventos de } \\
\text { relaciones públicas } \\
\text { como ejemplos de } \\
\text { acciones de } \\
\text { comunicación below } \\
\text { the line }\end{array}$ & $\begin{array}{l}\text { Promoción } \\
\text { turística }\end{array}$ & $\begin{array}{c}\text { Análisis con datos } \\
\text { secundarios }\end{array}$ & Datos secundarios & $\begin{array}{l}\text { Galicia } \\
\text { (España) }\end{array}$ & $\begin{array}{l}\text { Comunicación, evento, } \\
\text { relaciones públicas }\end{array}$ \\
\hline $\begin{array}{l}\text { Identidad territorial y } \\
\text { promoción turística: la } \\
\text { organización de } \\
\text { eventos como estrategia } \\
\text { de creación, } \\
\text { consolidación y } \\
\text { difusión de la imagen } \\
\text { de marca del territorio }\end{array}$ & $\begin{array}{l}\text { Imagen de } \\
\text { destino durante } \\
\text { el proceso de } \\
\text { decisión de } \\
\text { compra }\end{array}$ & $\begin{array}{c}\text { Revisión } \\
\text { bibliográfica }\end{array}$ & Datos secundarios & $\begin{array}{l}\text { Mundo en } \\
\text { general }\end{array}$ & $\begin{array}{c}\text { Comunicación, evento, } \\
\text { identidad, marca } \\
\text { territorio, turismo }\end{array}$ \\
\hline
\end{tabular}


Tabla IV. Análisis de las temáticas, metodologías, muestras, territorios objeto de estudio y palabras clave de los artículos seleccionados. Fuente: Elaboración propia.

\footnotetext{
Nace en 1988 con el nombre Comunicación y Sociedad. En octubre de 2014 cambia a Communication \& Society.

2 Nace en 1991 con el título Treballs de Comunicació. Cambia a Comunicació en 2010.

${ }^{3}$ Nace en 1992 como Information World en Español (IWE) y en 1998 cambia el título a El profesional de la información.
} 